\title{
Melter Off-Gas Flammability Assessment for DWPF Alternate Reductant Flowsheet Options
}

A. S. Choi

July 2011

Savannah River National Laboratory

Savannah River Nuclear Solutions, LLC

Aiken, SC 29808

Prepared for the U.S. Department of Energy under contract number DE-AC09-08SR22470.

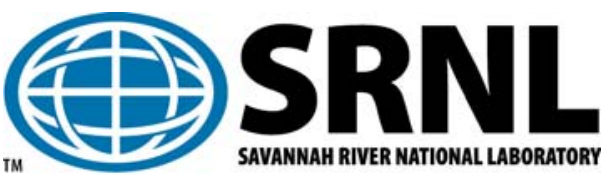


SRNL-STI-2011-00321

Revision 0

\section{DISCLAIMER}

This work was prepared under an agreement with and funded by the U.S. Government. Neither the U.S. Government or its employees, nor any of its contractors, subcontractors or their employees, makes any express or implied:

1. warranty or assumes any legal liability for the accuracy, completeness, or for the use or results of such use of any information, product, or process disclosed; or

2. representation that such use or results of such use would not infringe privately owned rights; or

3. endorsement or recommendation of any specifically identified commercial product, process, or service.

Any views and opinions of authors expressed in this work do not necessarily state or reflect those of the United States Government, or its contractors, or subcontractors.

\section{Printed in the United States of America \\ Prepared for \\ U.S. Department of Energy}


Keywords: DWPF, Melter OffGas Flammability, Alternate Reductants

Retention: Permanent

\title{
Melter Off-Gas Flammability Assessment for DWPF Alternate Reductant Flowsheet Options
}

\author{
A. S. Choi
}

July 2011

Savannah River National Laboratory

Savannah River Nuclear Solutions, LLC Aiken, SC 29808

Prepared for the U.S. Department of Energy under contract number DE-AC09-08SR22470.

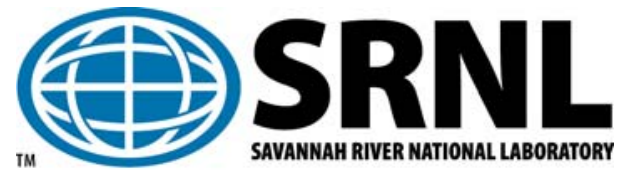




\section{REVIEWS AND APPROVALS}

\section{AUTHORS:}

A. S. Choi, Engineering Process Development

Date

TECHNICAL REVIEW:

F. G. Smith, III, Process Modeling \& Computational Chemistry

Date

APPROVAL:

C. C Herman, Manager

Date

Process Technology Programs / E\&CPT Research Programs

S.L. Marra, Manager

Date

Environmental \& Chemical Process Technology Research Programs

J. E. Occhipinti, Manager

Date

Waste Solidification Engineering/Savannah River Remediations 
SRNL-STI-2011-00321

Revision 0

\section{EXECUTIVE SUMMARY}

Glycolic acid and sugar are being considered as potential candidates to substitute for much of the formic acid currently being added to the DWPF melter feed as a reductant. A series of small-scale melter tests were conducted at the Vitreous State Laboratory (VSL) in January 2011 to collect necessary data for the scoping assessment of the impact of these alternate reductants on the melter off-gas flammability. The resulting data were analyzed in this work with the aid of modeling and re-baselined to reflect the DWPF melter operating conditions. Based on the results of these steady state analyses presented in this report, the following conclusions can be drawn:

1. The baseline formic acid flowsheet feed has $\sim 3 X$ higher melter off-gas flammability potential than either the glycolic acid or sugar-based flowsheet feed at measured vapor space temperatures $\leq 500{ }^{\circ} \mathrm{C}$.

2. The melter off-gas flammability potentials of the glycolic and sugar-based flowsheet feeds are similar at measured vapor space temperatures $\leq 500{ }^{\circ} \mathrm{C}$.

3. The $3 \mathrm{X}$ difference in melter off-gas flammability potential between the baseline and either alternate reductant feeds is expected to decrease significantly at typical vapor space operating temperatures $>500{ }^{\circ} \mathrm{C}$ for both bubbled and non-bubbled operations due to increased kinetics of $\mathrm{H}_{2}$ and $\mathrm{CO}$ oxidation.

4. Bubbling increases the melter off-gas flammability potential likely due to increased feed rate at a relatively constant air purge rate.

5. It appears that over $50 \%$ of the glycolate detected by IC in the glycolic flowsheet feed remained un-dissociated and exited the melter as such, thus having no significant impact on either the glass redox or melter off-gas flammability potential. The condensed glycolic acid will then have to be neutralized and recycled back to the Tank Farms.

6. The existing DWPF cold cap model under predicted the $\mathrm{H}_{2}$ and $\mathrm{CO}$ data taken during the baseline flowsheet feed runs. However, the under prediction was most likely caused by the inadequacy of data, which in turn was caused by the inherent difficulty of maintaining steady state operation under the non-prototypic design and operating conditions of the VSL melter coupled with the fact that insufficient run time was allocated to each steady state due to a limited supply of feed.

In order to confirm and further substantiate the conclusions of this work, it is recommended that:

1. A proof-of-principle testing be performed by employing a larger, continuously-fed and poured melter and allowing sufficient time for the system to reach steady state before data collection. A larger size will help; (1) maintain a more prototypic cold cap under both bubbled and non-bubbled conditions and (2) quantify off-gas surging potentials of the alternate reductant feeds relative to that of the baseline formic acid flowsheet feed. The continuous feeding and pouring capability will help maintain steady state better and longer.

2. Using the proof-of-principle test data, validate the formic acid decomposition and revised $\mathrm{H}_{2}$ oxidation models and further adjust the cold cap model for the selected alternate reductant flowsheet feed. 


\section{TABLE OF CONTENTS}

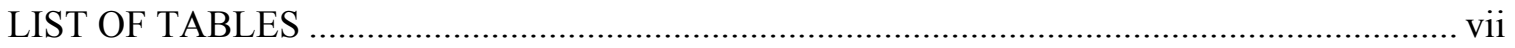

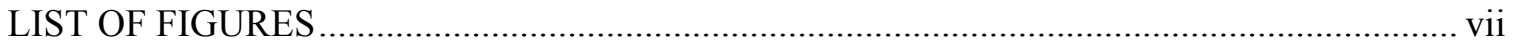

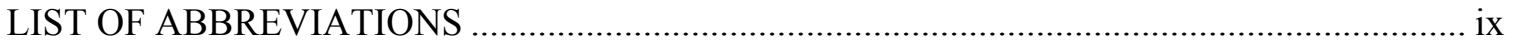

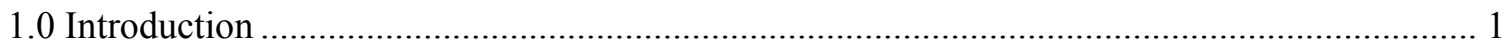

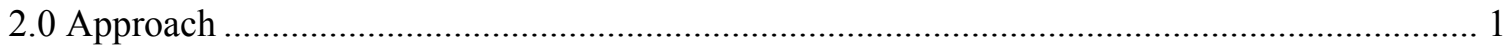

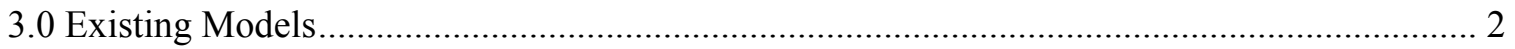

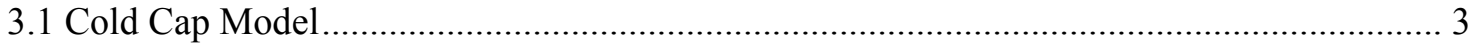

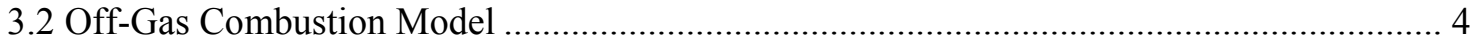

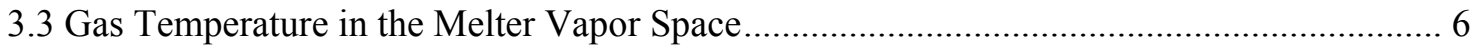

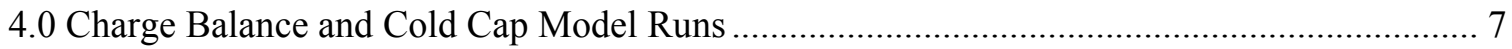

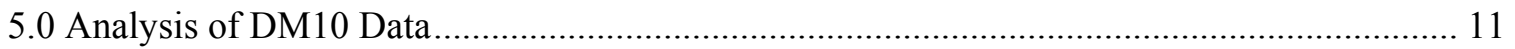

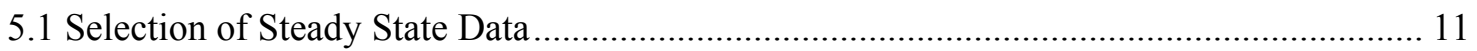

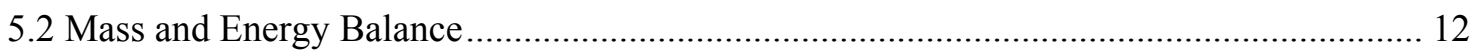

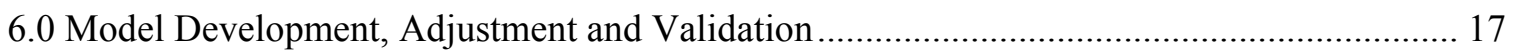

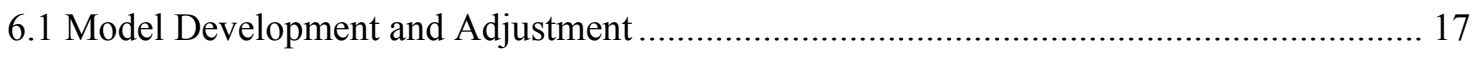

6.1.1 Adjustment of Cold Cap Model for Sugar Flowsheet Feed .......................................... 19

6.1.2 Development of Formic Acid Decomposition Model ................................................... 20

6.1.3 Adjustment of Vapor Space Combustion Model ......................................................... 21

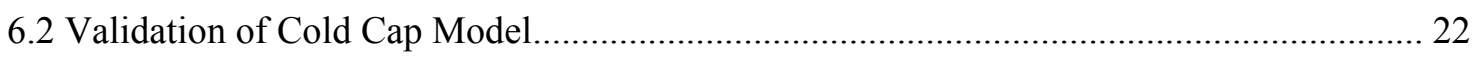

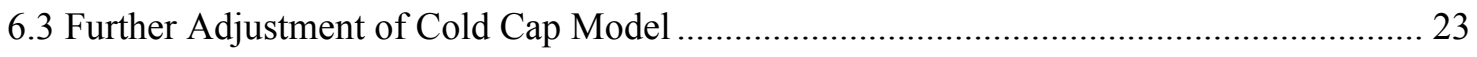

6.3.1 Development of Glycolic Acid Decomposition Model................................................. 23

6.3.2 Adjustment of Cold Cap Model for Glycolic Flowsheet Feed...................................... 25

6.4 Summary of Model Development, Adjustment and Validation ....................................... 25

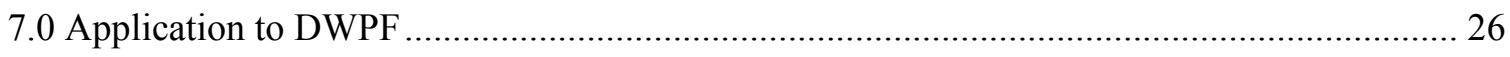

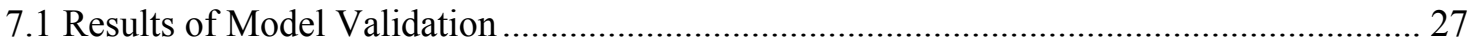

7.2 Impact of Feed Reductant on Off-Gas Flammability .................................................. 28

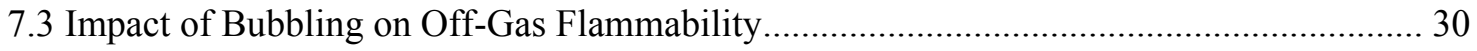

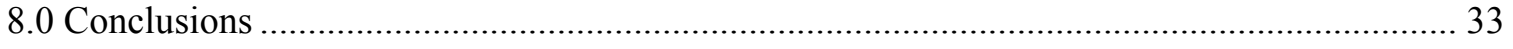

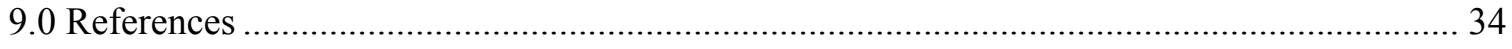

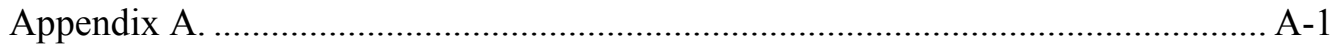




\section{LIST OF TABLES}

Table 3-1. First-Order Global Kinetic Parameters for Vapor Space Oxidation. ............................. 4

Table 4-1. Estimated Soluble Metal Fractions in GF24 Glycolic Acid Flowsheet Feed................. 8

Table 4-2. Results of Charge Balance for Baseline, Glycolic and Sugar Flowsheet Feeds.......... 8

Table 4-3. 4-Stage Cold Cap Model Input for the Baseline Flowsheet Feed at the DWPF Design

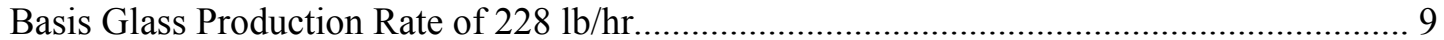

Table 4-4. 4-Stage Cold Cap Model Input for the Glycolic Flowsheet Feed at the DWPF Design

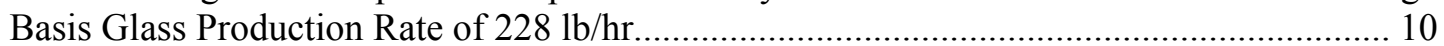

Table 4-5. 4-Stage Cold Cap Model Input for the Sugar Flowsheet Feed at the DWPF Design

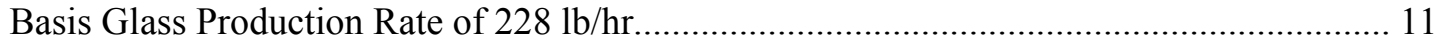

Table 5-1. Results of Steady State Mass and Energy Balance of DM10 Runs. .......................... 14

Table 6-1. Sugar Feed Data vs. Cold Cap Model Predictions (per 1.28 kg/hr Feed Rate)............ 19

Table 6-2. Baseline Feed Data vs. Cold Cap Model Predictions (per 1.28 kg/hr Feed Rate). ..... 22

Table 6-3. Glycolic Feed Data vs. Cold Cap Model Predictions (per 1.28 kg/hr Feed Rate)..... 23

Table 6-4. Summary of Cold Cap Model Adjustments (per 1.28 kg/hr Feed Rate).................... 26

\section{LIST OF FIGURES}

Figure 3-1. Calculated vs. Measured $\mathrm{H}_{2}$ Concentrations during 774-A Melter Run...................... 5

Figure 3-2. Calculated vs. Measured CO Concentrations during 774-A Melter Run.................... 5

Figure 3-3. Validation of Measured Vapor Space vs. Actual Gas Temperature Correlation Developed from SGM-9 Data. $^{7}$

Figure 5-1. Schematic of DM10 Sampling Locations................................................................ 12

Figure 5-2. Measured vs. Calculated Gas Temperature in DM10 Vapor Space. ......................... 15

Figure 5-3. Measured Vapor Space Temperature vs. $\Delta$ T during DM10 Runs. ............................. 16

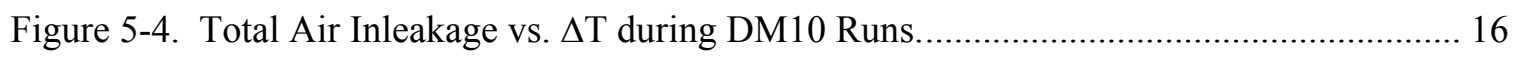

Figure 6-1. Gas Yield from Formic Acid Decomposition in Pyrex Glass Tube. ${ }^{14}$....................... 18

Figure 6-2. Overall Rate Constant of Formic Acid Decomposition at Varying Concentration and Temperature-taken from Ref. [16]. 
Figure 6-3. Formic Acid Decomposition and Dehydration Fractions during Non-Bubbled Sugar Feed Runs

Figure 6-4. Existing vs. Revised Global First-Order Rate Constants for Oxidation of $\mathrm{H}_{2}$ from Sugar Flowsheet Feed.

Figure 6-5. Effects of $\mathrm{Na}_{2} \mathrm{CO}_{3}$ Catalyst on $\mathrm{HCHO}$ Decomposition-catalyzed (open symbol); uncatalyzed (closed symbol)-taken from Ref. [18] ............................................................... 24

Figure 7-1. Predicted vs. Measured Off-Gas Flammability for Bubbled Baseline Feed Run...... 27

Figure 7-2. Predicted vs. Measured Off-Gas Flammability for Bubbled Glycolic Feed Run...... 28

Figure 7-3. Predicted vs. Measured Off-Gas Flammability for Bubbled Sugar Feed Run........... 29

Figure 7-4. Impact of Reductant on Off-Gas Flammability for Non-Bubbled Op...................... 29

Figure 7-5. Impact of Reductant on Off-Gas Flammability for Bubbled Op............................ 30

Figure 7-6. Impact of Bubbling on Off-Gas Flammability of Baseline Feed.............................. 31

Figure 7-7. Impact of Bubbling on Off-Gas Flammability of Glycolic Flowsheet Feed. ............ 31

Figure 7-8. Impact of Bubbling on Off-Gas Flammability of Sugar Flowsheet Feed.................. 32 


\section{LIST OF ABBREVIATIONS}

$\begin{array}{ll}\text { AD } & \text { Analytical Development } \\ \text { CPC } & \text { Chemical Processing Cell } \\ \text { CSTR } & \text { Continuous Stirred Tank Reactor } \\ \text { DWPF } & \text { Defense Waste Processing Facility } \\ \text { IC } & \text { Ion Chromatography } \\ \text { ICP } & \text { Invariant Condensed Phase } \\ \text { LFL } & \text { Lower Flammability Limit } \\ \text { MOG } & \text { Melter Off-Gas } \\ \text { PSAL } & \text { Process Science Analytical Laboratory } \\ \text { PSCM } & \text { Pilot-Scale Ceramic Melter } \\ \text { SCM-2 } & \text { Small Cylindrical Melter-II } \\ \text { SGM } & \text { Scale Glass Melter } \\ \text { SRAT } & \text { Sludge Receipt and Adjustment Tank } \\ \text { SRNL } & \text { Savannah River National Laboratory } \\ \text { TOC } & \text { Total Organic Carbon } \\ \text { TSR } & \text { Technical Safety Requirements } \\ \text { VSL } & \text { Vitreous State Laboratory }\end{array}$




\subsection{Introduction}

Glycolic acid and sugar are being considered as potential candidates to substitute for much of the formic acid currently being added to the DWPF melter feed as a reductant. A series of small-scale melter tests were conducted at the Vitreous State Laboratory (VSL) in January 2011 to collect necessary data for the assessment of the impact of these alternate reductants on the melter off-gas flammability. The DM10 melter with a $0.021 \mathrm{~m}^{2}$ melt surface area was run with three different feeds which were prepared at SRNL based on; (1) the baseline formic/nitric acid flowsheet, (2) glycolic/formic/nitric acid flowsheet, and (3) sugar/formic/nitric acid flowsheet - these feeds will be called the baseline, glycolic, and sugar flowsheet feeds, respectively, hereafter. The actual addition of sugar to the sugar flowsheet feed was made at VSL before it was fed to the melter.

For each feed, the DM10 was run under both bubbled (with argon) and non-bubbled conditions at varying melter vapor space temperatures. The goal was to lower its vapor space temperature from nominal $500{ }^{\circ} \mathrm{C}$ to less than $300{ }^{\circ} \mathrm{C}$ at $50{ }^{\circ} \mathrm{C}$ increments and maintain steady state at each temperature at least for one hour, preferentially for two hours, while collecting off-gas data including $\mathrm{CO}, \mathrm{CO}_{2}$, and $\mathrm{H}_{2}$ concentrations. ${ }^{1}$ Just a few hours into the first test with the baseline feed, it was discovered that the DM10 vapor space temperature would not readily fall below 350 ${ }^{\circ} \mathrm{C}$ simply by ramping up the feed rate as the test plan called for. To overcome this, ambient air was introduced directly into the vapor space through a dilution air damper in addition to the natural air inleakage occurring at the operating melter pressure of -1 inch $\mathrm{H}_{2} \mathrm{O}$. A detailed description of the DM10 run along with all the data taken is given in the report issued by VSL.,3

The SRNL personnel have analyzed the DM10 data and identified 25 steady state periods lasting from 32 to 92 minutes for all six melter runs (bubbled and non-bubbled runs for each of the three feeds). The steady state selection was made by limiting the standard deviation of the average vapor space temperature readings from two bare thermocouples (TT-03 and TT-05) to less than 5 ${ }^{\circ} \mathrm{C}$ in most cases at a constant feed rate. The steady state data thus selected were mass and heat balanced and the off-gas data were re-baselined to assess the flammability potential of each feed under the DWPF melter operating conditions. Efforts were made to extract as much information out of the data as possible necessary to extend the applicability of the existing baseline cold cap and off-gas combustion models to the glycolic and sugar flowsheet feeds. This report details the outcome of these activities.

\subsection{Approach}

The overall task proceeded in the following sequence: ${ }^{4}$

A. Develop the melter feed compositions by charge balancing available analytical data for the SRAT products and blending them with Frit 418 at 36\% waste loading. The amount of sucrose added to the sugar flowsheet feed was based on the recipe by the VSL.

B. Run the existing DWPF cold cap and vapor space combustion models with each feed composition and calculate the resulting melter off-gas compositions.

C. Extract steady state data based on the average of the two DM10 vapor space temperature readings from exposed thermocouples.

D. Perform mass and energy balance on each steady state data set and calculate the total melter air inleakage rate (including both natural and forced) and the actual vapor space gas temperature. 
E. Review the results of mass and energy balance and identify the most consistent steady state data set preferably for the baseline feed and, if necessary, adjust the cold cap model to match the redox and off-gas data taken at the lowest vapor space temperature.

F. Develop the gas-phase decomposition models of formic and glycolic acids using the most consistent data set and validate them against the remaining data sets.

G. Re-baseline both the data and the revised model output to reflect the DWPF safety basis maximum feed rate to air purge ratio and calculate the steady state off-gas flammability potentials in terms of the percent of the lower flammability limit (LFL).

H. Compare the outcome of Step G for the three flowsheet feeds and make final assessments.

\subsection{Existing Models}

The potential for off-gas flammability in the DWPF melter system is mitigated by controlling the following process/operating variables under a baseline upset scenario; (1) the total organic carbon (TOC) to nitrate ratio in the feed, (2) melter air purges, and (3) melter vapor space temperature. Currently, the Technical Safety Requirements (TSR) and feed interlocks are set on these variables by applying appropriate analytical and/or instrument uncertainties to the following theoretical limits: ${ }^{5}$

* Maximum TOC-to-nitrate ratio at antifoam carbon $\leq 2,013 \mathrm{ppm}$

$$
\mathrm{TOC} /\left[\mathrm{NO}_{3}\right] \leq 7.2791 \mathrm{E}-10\left[\mathrm{NO}_{3}\right]^{2}-5.0035 \mathrm{E}-05\left[\mathrm{NO}_{3}\right]+1.5347
$$

* Minimum total melter air purge $($ FIC3221A $)=900 \mathrm{lb} / \mathrm{hr}$

* Minimum backup film cooler air purge $($ FIC3221B $)=233 \mathrm{lb} / \mathrm{hr}$

* $\quad$ Minimum melter vapor space temperature $(\mathrm{TI} 4085 \mathrm{D})=460{ }^{\circ} \mathrm{C}$

The impact of TOC, nitrate, air purges, vapor space temperature, and feed rate on the melter offgas flammability is highly interdependent. For example, when the TOC is increased at constant vapor space temperature and air flows, it must be ensured that the nitrate level is high enough to satisfy Eq. (1). On the other hand, when the TOC is increased at fixed air flows and nitrate, the vapor space temperature would have to be increased in order to burn the excess carbon.

Two computer models have been used to describe this interdependency quantitatively and further set the operating limits of these variables in the form of feed interlocks and TSR limits, as shown above. The 4-stage cold cap model describes the chemistry of the melter cold cap reactions thermodynamically and predicts the compositions of both calcine gases and glass from a given feed composition. The calculated composition of calcine gases is then used as the input to the second model, called the melter off-gas (MOG) dynamics model, which predicts the transient response of the DWPF melter off-gas system, including the potential for off-gas flammability, for a given upset scenario. The baseline upset scenario used in the MOG flammability safety basis is the off-gas surge. However, since the scope of this task is limited to steady state analysis, only the vapor space combustion kinetics portion of the MOG dynamics model will be run at the vapor space gas temperature and gas residence time using the calcine gas composition calculated by the cold cap model. 
Since a detailed description of the cold cap and MOG dynamics models along with the validation results is given elsewhere, ${ }^{6-8}$ only some of the key features of each model are highlighted next.

\subsection{Cold Cap Model}

It is assumed that all the species present in the cold cap are in thermodynamic equilibrium with one another, thus ignoring such rate effects as chemical kinetics and transport resistances within various phases that form among a very large number of waste components and glass-forming frit. To better represent the gradual nature of the melting process, the entire cold cap is modeled as a continuous, 4-stage countercurrent reactor. The gas and solids products are allowed to reach equilibrium in each stage, before the former is passed on to the next stage up, while the latter is passed on to the next stage down, thereby maintaining countercurrent gas-solids flows between stages. ${ }^{6}$

The temperature of each stage is set progressively higher from $700^{\circ} \mathrm{C}$ at the top (Stage 1) to the final melt temperature of $1150^{\circ} \mathrm{C}$ at the bottom (Stage 4). The temperature of Stage 1 was set based on the finding that the calculated molar ratio of $\mathrm{CO}$ to $\mathrm{CO}_{2}$ in the calcine gas at $700{ }^{\circ} \mathrm{C}$ closely matched measured data. ${ }^{7}$ The volatile feed components such as free $\mathrm{H}_{2} \mathrm{O}$ and other lowboiling species are assumed to boil off upon entering the melter and only the remaining nonvolatile components are allowed to enter the cold cap. Furthermore, hydroxides and most of the salt species except sulfates are pre-decomposed and fed as oxides and gaseous products as shown:

$$
\text { Stage 1: } \quad \begin{aligned}
2 \mathrm{Fe}(\mathrm{OH})_{3} & \rightarrow \mathrm{Fe}_{2} \mathrm{O}_{3}+3 \mathrm{H}_{2} \mathrm{O} \\
2 \mathrm{NaCOOH} & \rightarrow \mathrm{Na}_{2} \mathrm{C}_{2} \mathrm{O}_{4}+\mathrm{H}_{2} \\
& 2 \mathrm{NaNO}_{3} \rightarrow 2 \mathrm{NaNO}_{2}+\mathrm{O}_{2} \\
\text { Stage 2: } \quad & \mathrm{Na}_{2} \mathrm{C}_{2} \mathrm{O}_{4} \rightarrow \mathrm{Na}_{2} \mathrm{CO}_{3}+\mathrm{CO} \\
& \mathrm{Na}_{2} \mathrm{CO}_{3} \rightarrow \mathrm{Na}_{2} \mathrm{O}+\mathrm{CO}_{2} \\
& 2 \mathrm{NaNO}_{2} \rightarrow \mathrm{Na}_{2} \mathrm{O}+\mathrm{NO}+\mathrm{NO}_{2}
\end{aligned}
$$

Due to its low decomposition temperature, the formate decomposes into the oxalate in Stage 1 via Eq. (3), thereby releasing $\mathrm{H}_{2}$ early on. The oxalate thus formed and those already in the feed decompose into $\mathrm{CO}$ and $\mathrm{CO}_{2}$ with carbonate as the intermediate product in Stage 2. The nitrate decomposes into nitrite and $\mathrm{O}_{2}$ in Stage 1, and the subsequent decomposition of nitrite is allowed to proceed through Stage 3 via Eq. (7).

In Stage 3, the spinels are allowed to form by combining two oxides at different oxidation states. For example, the nickel-iron spinels are formed by combining $\mathrm{Ni}(\mathrm{II}) \mathrm{O}$ and $\mathrm{Fe}(\mathrm{III})_{2} \mathrm{O}_{3}$ as shown by Eq. (8). Due to structural similarities, these spinels readily form solid solutions with one another and thus are assumed to form a separate phase of their own. On the other hand, those species that do not form solid solutions with other species are included in the Invariant Condensed Phase (ICP), i.e., each ICP species forms a separate phase by itself. Therefore, as more species are included in the ICP group, the number of phases to be considered in the equilibrium calculations increases, thus making convergence more difficult to achieve. Finally, the condensed products from Stage 3 are converted into the glass melt in Stage 4 by forming various silicate compounds, as shown by Eq. (9); the letter "l” after each species denotes "liquid." 


$$
\begin{array}{ll}
\text { Stage 3: } & \mathrm{NiO}+\mathrm{Fe}_{2} \mathrm{O}_{3} \rightarrow \mathrm{NiFe}_{2} \mathrm{O}_{4} \\
\text { Stage 4: } & \mathrm{Na}_{2} \mathrm{Ol}+\mathrm{SiO}_{2} \mathrm{l} \rightarrow \mathrm{Na}_{2} \mathrm{SiO}_{3} \mathrm{l}
\end{array}
$$

\subsection{Off-Gas Combustion Model}

The flammable components of the calcine gases along with those that boil off upon entering the melter react further in the vapor space before exiting the melter. The first-order global kinetic parameters of $\mathrm{CO}$ and $\mathrm{H}_{2}$ oxidation used in the current MOG dynamics model were developed using the data taken from the $1 / 2$ DWPF-scale (based on melt surface area) Scale Glass Melter (SGM) fed with the formic flowsheet feed spiked with high-boiling aromatic compounds: ${ }^{7}$

$$
-r=k_{o} \exp \left(-E_{a} / R T\right) C
$$

where $-r$ is the reaction rate in $1 \mathrm{bmole} / \mathrm{ft}^{3} / \mathrm{sec}, k_{o}$ the pre-exponential factor in $1 / \mathrm{sec}, E_{a}$ the activation energy in Btu/lbmole, $R$ the gas constant, $T$ the gas temperature in $\mathrm{K}$, and $C$ the concentration of $\mathrm{CO}$ or $\mathrm{H}_{2}$ in lbmole/ $\mathrm{ft}^{3}$. The resulting kinetic parameters empirically fitted to the SGM data are given in Table 3-1.

Table 3-1. First-Order Global Kinetic Parameters for Vapor Space Oxidation.

\begin{tabular}{||c|c|c|c||}
\hline \hline & $\begin{array}{c}k_{0} \\
(1 / \mathrm{sec})\end{array}$ & $\begin{array}{c}E_{a} \\
(\text { Btu/lbmole })\end{array}$ & $\mathrm{R}^{2}$ \\
\hline $\mathrm{CO}$ & 1,759 & 22,192 & 0.845 \\
\hline $\mathrm{H}_{2}$ & $2.795 \mathrm{E} 7$ & 38,940 & 0.999 \\
\hline
\end{tabular}

These global kinetic parameters were validated against the data taken from the $1 / 25$ scale Small Cylindrical Melter-II (SCM-2) as well as the 1/80 scale 774-A research melter both fed with the formic acid flowsheet feeds as shown in Figure 3-1 and Figure 3-2. The calculated concentrations of $\mathrm{H}_{2}$ and $\mathrm{CO}$ per mole of $\mathrm{COOH}$ fed are shown to bound the measured data well except for a few apparent outliers.

It is known that the combustion of formic acid vapor is slow compared to thermal decomposition, and decomposition can proceed via two parallel pathways: ${ }^{9}$

$$
\begin{array}{lll}
\text { Dehydration: } & \mathrm{HCOOH} & \stackrel{k_{1}}{\rightarrow} \mathrm{CO}+\mathrm{H}_{2} \mathrm{O} \\
\text { Decarboxylation: } & \mathrm{HCOOH} \stackrel{k_{2}}{\rightarrow} \mathrm{CO}_{2}+\mathrm{H}_{2}
\end{array}
$$

The gas-phase experiments show that the $\mathrm{CO}$ yield is substantially greater than the $\mathrm{CO}_{2}$ yield, which indicates that dehydration is the primary pathway, while the aqueous-phase experiments point to decarboxylation as the primary pathway. Based on these experimental observations, the free formic acid that boiled off from the 774-A melter feed was allowed to decompose to $\mathrm{CO}$ and $\mathrm{H}_{2} \mathrm{O}$ in the vapor space for the calculation of the model-predicted curves in Figure 3-1 and Figure $3-2.9^{9,10}$ 


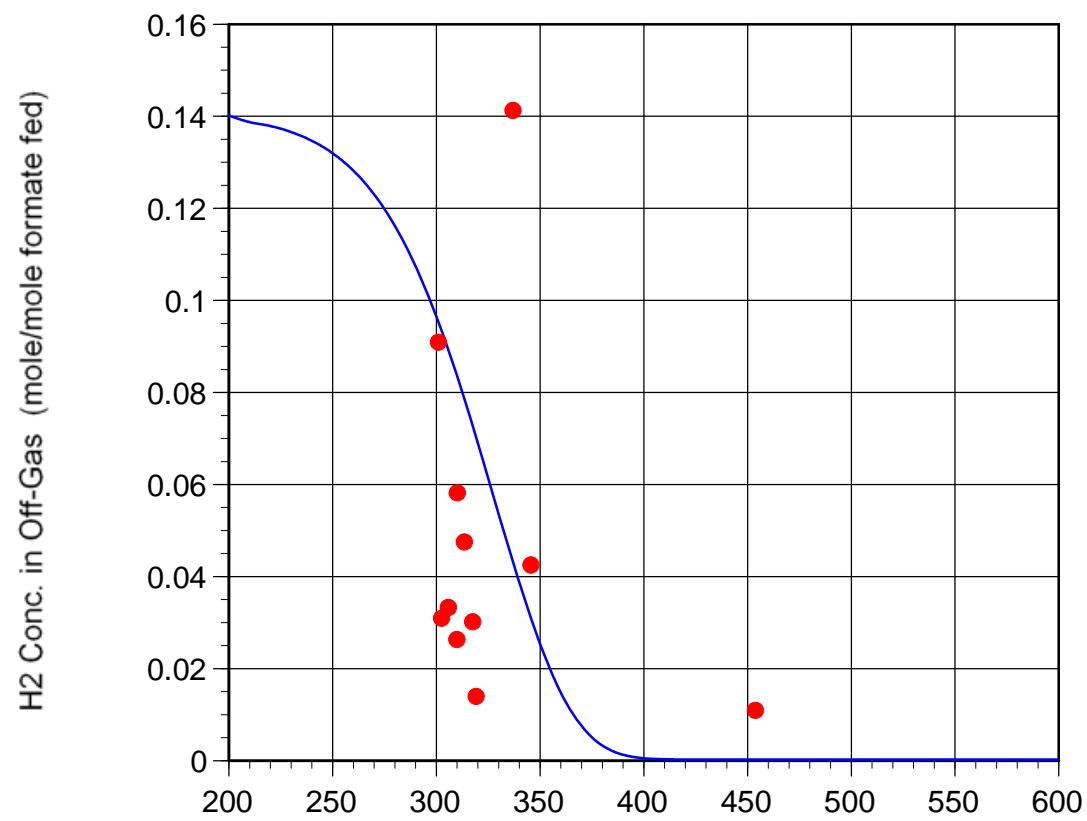

True Gas Temperature (deg C)

Figure 3-1. Calculated vs. Measured $\mathrm{H}_{2}$ Concentrations during 774-A Melter Run.

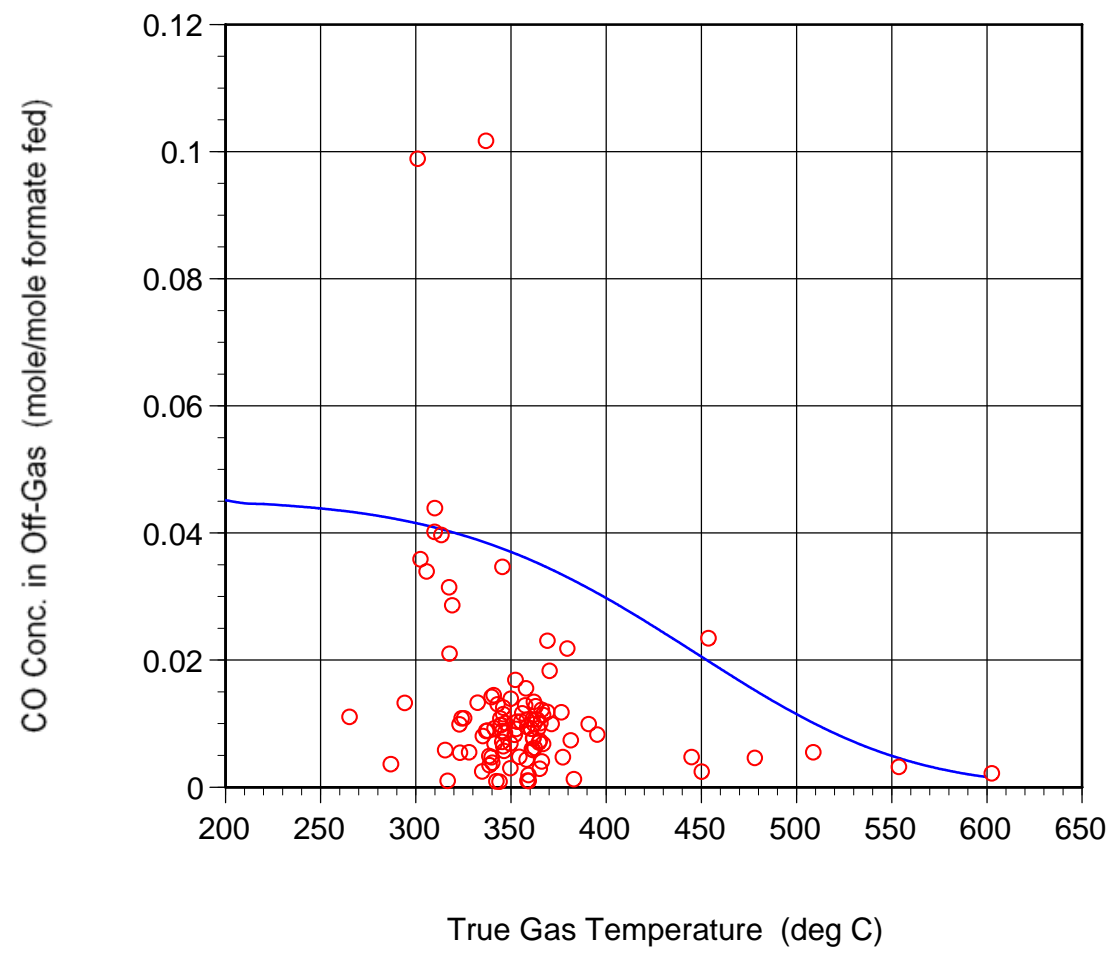

Figure 3-2. Calculated vs. Measured CO Concentrations during 774-A Melter Run. 


\subsection{Gas Temperature in the Melter Vapor Space}

In Figure 3-1 and Figure 3-2, the predicted concentrations of $\mathrm{H}_{2}$ and $\mathrm{CO}$ are plotted against the true vapor space gas temperatures rather than the measured values. This is because the measured temperature readings unavoidably include the effect of thermal radiation impinging on the thermowell or exposed thermocouples and, therefore, tend to be considerably higher than the corresponding gas temperatures and it is the gas temperature that determines the combustion kinetics. There have been a few attempts made so far to measure the true gas temperature without the interference of radiation shine from the lid heaters, refractory walls and even the melt surface but all without much success.

To overcome this problem, the mass and energy balance around the film cooler was done during the SGM-9 run to estimate the true vapor space gas temperatures, and the following correlation between the measured vs. actual gas temperatures was derived: ${ }^{11}$

$$
T_{\text {gas }}=0.91685 T_{\text {measured }}-128, \quad T_{\text {measured }} \leq 705^{\circ} \mathrm{C}
$$

Since the thermal radiation is the dominant mode of heat transfer in the vapor space, it is expected that the design configuration of the melter internals such as lid heaters and refractory walls would have a profound impact on the difference between the measured and true gas temperatures in the vapor space. Based on the fact that the design of the SGM melter and vapor space internals was identical to the DWPF melter, except for being a 2/3 linear scale, one would expect that Eq. (13) should in principle also apply to the DWPF melter. As shown in Figure 3-3, this was indeed the case, although it seems to under predict the DWPF-2 data somewhat, which is conservative from the off-gas flammability standpoint.

Eq. (13) was further validated against the Pilot-Scale Ceramic Melter (PSCM) data taken at the Pacific Northwest Laboratory. ${ }^{12}$ A good agreement is again shown between the calculated PSCM vapor space gas temperatures and those predicted by Eq. (13). This was expected since the PSCM also had horizontal lid heater tubes and, like the SGM and DWPF melter, its aspect ratio was one. The aspect ratio is defined here as the ratio of the cross-sectional area of the vapor space to the melt surface area. Therefore, a melter with an aspect ratio of greater than one would have an expanded vapor space so that its vapor space thermowell would receive more thermal radiation from the refractory walls, resulting in a greater difference between the measured vapor space and true gas temperatures than those with an aspect ratio of one. This has been proven to be the case for the SCM-2 and the Integrated DWPF Melter System (IDMS) melter. ${ }^{7}$ Since the DM10 also has horizontal lid heaters and an aspect ratio of greater than one, it is expected that the true vapor space gas temperature would be at most equal to or lower than those predicted by Eq. (13) for the range of measured vapor space temperatures $\left(\mathrm{T}_{\text {measured }}\right) \geq 500{ }^{\circ} \mathrm{C}$.

However, the effect of thermal radiation will become less and less pronounced as the vapor space temperature decreases, as shown qualitatively by the dotted line in Figure 3-3. Since the DM10 test was run exclusively at vapor space temperatures at $500{ }^{\circ} \mathrm{C}$ or lower, this expected trend of decreasing thermal radiation with decreasing temperature will be verified using the DM10 data. Here, the decreasing thermal radiation means that the difference between the measured and actual gas temperature becomes smaller:

$$
\Delta T=T_{\text {measured }}-T_{\text {gas }}
$$




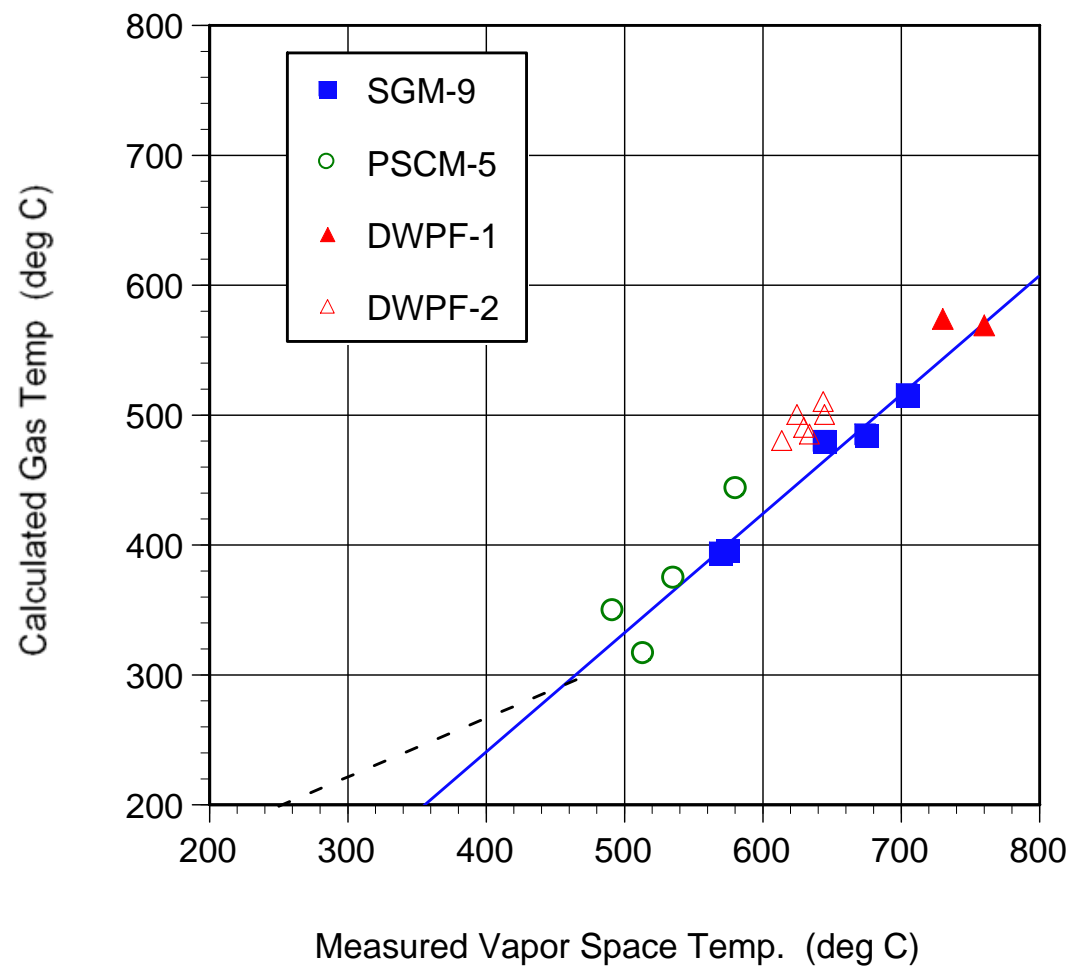

\section{Figure 3-3. Validation of Measured Vapor Space vs. Actual Gas Temperature Correlation Developed from SGM-9 Data. ${ }^{7}$}

\subsection{Charge Balance and Cold Cap Model Runs}

The analytical data used in this work for the SRAT products are reported in the final report of the Chemical Processing Cell (CPC) demonstration of alternate reductant feeds. ${ }^{13}$ Charge balance was performed first by calculating the fractions of formate and glycolate that were reported in the Ion Chromatography (IC) data but would remain undissocated at the reported $\mathrm{pH}$ values. The $\mathrm{pK}_{\mathrm{a}}$ values used for the formic and glycolic acids were 3.75 and 3.83 , respectively, at $25^{\circ} \mathrm{C}$. For the baseline feed, it was determined that the best charge balance could be achieved by using the IC results from the repeat analysis by the Analytical Development (AD) section. On the other hand, for the glycolic and sugar flowsheet feeds, the IC results from the Process Science Analytical Laboratory (PSAL) were used except for the formate of the latter feed. The IC results of sulfate were split between soluble and insoluble fractions during the charge balance, and the insoluble fraction was assigned as $\mathrm{CaSO}_{4}$.

Critical to the success of charge balance particularly for the glycolic flowsheet feed are the elemental results of the supernate samples, which enable one to estimate the soluble fraction of non-alkali metal species. Unfortunately, no supernate analysis was performed on the glycolic flowsheet feed (GF24) that was sent to the VSL. Therefore, available supernate data for the GF3 and GF6 feeds, ${ }^{13}$ both of which were also the glycolic flowsheet feeds but at $125 \%$ and $100 \%$ acid stoichiometry, respectively, were used to estimate the soluble fraction of non-alkali metals in the GF24 at 110\% acid stoichiometry by interpolation, as shown in Table 4-1. For the baseline and sugar flowsheet feeds, the soluble fractions of $\mathrm{Ca}, \mathrm{Mg}$, and $\mathrm{Ni}$ were set at 0.1 , while that of Mn was varied until charge balance was achieved. The impact of glycolic acid on the solubility of metals is clearly seen in the final charge balance results summarized in Table 4-2. 
SRNL-STI-2011-00321

Revision 0

Table 4-1. Estimated Soluble Metal Fractions in GF24 Glycolic Acid Flowsheet Feed.

\begin{tabular}{||c|c|c|c|c|c|c|c|c|c|c|c|c||}
\hline soluble & $\mathrm{Fe}$ & $\mathrm{Al}$ & $\mathrm{Mn}$ & $\mathrm{Ca}$ & $\mathrm{Mg}$ & $\mathrm{Ni}$ & $\mathrm{Cr}$ & $\mathrm{Cu}$ & $\mathrm{S}$ & $\mathrm{Si}$ & $\mathrm{Zn}$ & $\mathrm{Zr}$ \\
\hline \% total & 7.03 & 2.55 & 75.80 & 98.09 & 44.58 & 32.25 & 2.15 & 30.39 & 90.47 & 32.03 & 31.16 & 21.53 \\
\hline
\end{tabular}

Table 4-2. Results of Charge Balance for Baseline, Glycolic and Sugar Flowsheet Feeds.

\begin{tabular}{||c|c|c|c|c|c|c|c|c|c|c||}
\hline \hline \multirow{2}{*}{ Feed } & \multirow{2}{*}{$\mathrm{pH}$} & $\mathrm{CO}_{2} \mathrm{H}$ & $\begin{array}{c}\text { Free } \\
\mathrm{HCO}_{2} \mathrm{H}\end{array}$ & $\mathrm{NO}_{3}$ & $\mathrm{C}_{2} \mathrm{H}_{3} \mathrm{O}_{3}$ & $\begin{array}{c}\text { Free } \\
\mathrm{C}_{2} \mathrm{H}_{4} \mathrm{O}_{3}\end{array}$ & $\begin{array}{c}\text { Total } \\
\text { Anion }\end{array}$ & $\mathrm{Na}$ & $\begin{array}{c}\text { Soluble } \\
\text { Metals }\end{array}$ & $\begin{array}{c}\text { Total } \\
\text { Cation }\end{array}$ \\
\cline { 3 - 25 } & & $(\mathrm{ppm})$ & $(\%)$ & $(\mathrm{ppm})$ & $(\mathrm{ppm})$ & $(\%)$ & $\begin{array}{c}(\text { equiv } \\
\text { M) }\end{array}$ & $\begin{array}{c}\text { (equiv } \\
\text { M) }\end{array}$ & $\begin{array}{c}\text { (equiv } \\
\text { M) }\end{array}$ \\
\hline Baseline & 4.15 & 66,736 & 28.5 & 23,669 & - & $\mathrm{n} / \mathrm{a}$ & 1.77 & 1.52 & 0.26 & 1.78 \\
\hline Glycolic & 3.04 & 9,520 & 42.9 & 68,600 & 54,200 & 51.2 & 2.02 & 1.28 & 0.73 & 2.00 \\
\hline Sugar & 4.67 & 12,700 & 10.7 & 71,335 & - & $\mathrm{n} / \mathrm{a}$ & 1.76 & 1.51 & 0.27 & 1.78 \\
\hline
\end{tabular}

The results of charge balancing also show that significant fractions of formic and glycolic acids added would remain undissociated at the measured $\mathrm{pH}$ 's. This means that these undissociated acids will boil off upon entering the melter along with the free $\mathrm{H}_{2} \mathrm{O}$ in the feed only to decompose and react later in the vapor space, thus complicating the analysis of DM10 off-gas data. It in turn means that more high-quality off-gas data are required over a wider temperature range in order to extract sufficient information to model the vapor space decomposition and combustion of these acid vapors.

The charge-balanced SRAT product of each feed was next blended with Frit 418 at $36 \%$ waste loading to form the melter feed compositions, which were then pre-decomposed according to Eq. (2)-(7) to form the input vectors for the 4-stage cold cap model. The resulting cold cap model input vectors are shown in Table 4-3, Table 4-4, and Table 4-5 for the baseline, glycolic, and sugar flowsheet feeds, respectively. Due to its low decomposition temperature, the glycolate was fed only to Stage 1 after the following pre-decomposition for sodium glycolate as an example:

Stage 1: $\quad 2 \mathrm{Na}\left(\mathrm{HOCH}_{2} \mathrm{COO}\right) \rightarrow \mathrm{Na}_{2} \mathrm{O}+\mathrm{CO}_{2}+3 \mathrm{CO}+3 \mathrm{H}_{2}$

Sugar was added as sucrose at the sugar ratio of 0.875 , which is equivalent to 0.585 molar ratio of nitrate to TOC, including the carbon in the sucrose added. ${ }^{2}$ Sucrose was then pre-decomposed as:

$$
\mathrm{C}_{12} \mathrm{H}_{22} \mathrm{O}_{11} \rightarrow 12 \mathrm{C}+11 \mathrm{H}_{2} \mathrm{O}
$$

The "carbon" product of Reaction (16) was fed to Stages 1, 2 and 3 at the same ratio of 30:50:20, respectively, as the nitrate decomposition products are split. However, the water from Reaction (16) was fed to Stages 1 and 2 at the 75:25 ratio noting that the abundant $\mathrm{OH}$ groups in the sucrose molecule are readily released as $\mathrm{H}_{2} \mathrm{O}$. The results of the scoping cold cap model runs showed that if the water from Reaction (16) survived to Stage 3 or 4, it would readily reduce to $\mathrm{H}_{2}$ according to thermodynamics, thus making the glass overly oxidizing.

The results of the cold cap model runs, including the compositions of glass and calcine gases, are shown later in the Model Adjustment and Validation section of this report for direct comparison with their respective DM10 data, particularly the $\mathrm{H}_{2}$ and $\mathrm{CO}$ readings taken at low vapor space temperatures. The validity of the calculated glass compositions will be checked by comparing against measured glass redox ratios $\left(\mathrm{Fe}^{2+} / \mathrm{Fe}^{\text {total }}\right)$ in closed crucibles. 
Table 4-3. 4-Stage Cold Cap Model Input for the Baseline Flowsheet Feed at the DWPF Design Basis Glass Production Rate of $228 \mathrm{lb} / \mathrm{hr}$.

\begin{tabular}{|c|c|c|c|}
\hline Species & Stage 1 & Stage 2 & Stage 3 \\
\hline & gmole $/ \mathrm{hr}$ & gmole $/ \mathrm{hr}$ & gmole $/ \mathrm{hr}$ \\
\hline \multicolumn{4}{|c|}{ Non-Volatile Feed: } \\
\hline $\mathrm{Al}_{2} \mathrm{O}_{3}$ & 0 & 113.3110 & 0 \\
\hline $\mathrm{B}_{2} \mathrm{O}_{3}$ & 76.0578 & 0 & 0 \\
\hline $\mathrm{CaO}$ & & 1.2321 & 0 \\
\hline $\mathrm{CuO}$ & 1.6076 & 0 & 0 \\
\hline $\mathrm{Fe}_{2} \mathrm{O}_{3}$ & 71.0577 & 0 & 0 \\
\hline $\mathrm{K}_{2} \mathrm{O}$ & 0.2647 & 0 & 0 \\
\hline $\mathrm{Li}_{2} \mathrm{O}$ & 0 & 177.2137 & 0 \\
\hline $\mathrm{MgO}$ & 0 & 0 & 7.02985 \\
\hline $\mathrm{MnO}_{2}$ & 0 & 23.3731 & 0 \\
\hline $\mathrm{MnO}$ & 20.0714 & 0 & 0 \\
\hline $\mathrm{Na}_{2} \mathrm{O}$ & 132.1391 & 85.4331 & 0 \\
\hline $\mathrm{NiO}$ & 17.4004 & 0 & 0 \\
\hline $\mathrm{SiO}_{2}$ & 839.2648 & 0 & 0 \\
\hline $\mathrm{CaSO}_{4}$ & 0 & 0 & 4.1131 \\
\hline $\mathrm{Na}_{2} \mathrm{SO}_{4}$ & 0 & 0 & 1.3252 \\
\hline carbon & 0 & 0 & 0 \\
\hline $\mathrm{H}_{2} \mathrm{O}$ & 578.8764 & 0 & 0 \\
\hline $\mathrm{CO}$ & 0 & 114.3157 & 0 \\
\hline $\mathrm{CO}_{2}$ & 0 & 114.3157 & 0 \\
\hline $\mathrm{H}_{2}$ & 114.3157 & 0 & 0 \\
\hline $\mathrm{O}_{2}$ & 12.3411 & 20.5684 & 8.2274 \\
\hline $\mathrm{NO}$ & 12.3411 & 20.5684 & 8.2274 \\
\hline $\mathrm{NO}_{2}$ & 12.3411 & 20.5684 & 8.2274 \\
\hline \multicolumn{4}{|c|}{ Volatile Feed to Vapor Space: } \\
\hline $\mathrm{H}_{2} \mathrm{O}$ & \multicolumn{3}{|c|}{$10,313.2616$} \\
\hline $\mathrm{HCOOH}$ & \multicolumn{3}{|c|}{110.4492} \\
\hline
\end{tabular}


Table 4-4. 4-Stage Cold Cap Model Input for the Glycolic Flowsheet Feed at the DWPF Design Basis Glass Production Rate of $228 \mathrm{lb} / \mathrm{hr}$.

\begin{tabular}{|c|c|c|c|}
\hline Species & Stage 1 & Stage 2 & Stage 3 \\
\hline & gmole/hr & gmole/hr & gmole $/ \mathrm{hr}$ \\
\hline \multicolumn{4}{|c|}{ Non-Volatile Feed: } \\
\hline $\mathrm{Al}_{2} \mathrm{O}_{3}$ & 0 & 109.8906 & 0 \\
\hline $\mathrm{B}_{2} \mathrm{O}_{3}$ & 76.05786 & 0 & 0 \\
\hline $\mathrm{CaO}$ & & 4.9448 & 0 \\
\hline $\mathrm{CuO}$ & 1.52017 & 0 & 0 \\
\hline $\mathrm{Fe}_{2} \mathrm{O}_{3}$ & 66.4082 & 0 & 0 \\
\hline $\mathrm{K}_{2} \mathrm{O}$ & 0.2470 & 0 & 0 \\
\hline $\mathrm{Li}_{2} \mathrm{O}$ & 0 & 177.2137 & 0 \\
\hline $\mathrm{MgO}$ & 0 & 0 & 7.0734 \\
\hline $\mathrm{MnO}_{2}$ & 0 & 10.5585 & 0 \\
\hline $\mathrm{MnO}$ & 33.0788 & 0 & 0 \\
\hline $\mathrm{Na}_{2} \mathrm{O}$ & 116.2276 & 86.3780 & 0 \\
\hline $\mathrm{NiO}$ & 17.3465 & 0 & 0 \\
\hline $\mathrm{SiO}_{2}$ & 839.3154 & 0 & 0 \\
\hline $\mathrm{CaSO}_{4}$ & 0 & 0 & 0.1004 \\
\hline $\mathrm{Na}_{2} \mathrm{SO}_{4}$ & 0 & 0 & 6.4456 \\
\hline carbon & 0 & 0 & 0 \\
\hline $\mathrm{H}_{2} \mathrm{O}$ & 548.4265 & 0 & 0 \\
\hline $\mathrm{CO}$ & 125.5329 & 15.2691 & 0 \\
\hline $\mathrm{CO}_{2}$ & 41.8443 & 15.2691 & 0 \\
\hline $\mathrm{H}_{2}$ & 138.3107 & 0 & 0 \\
\hline $\mathrm{O}_{2}$ & 39.3722 & 65.6203 & 26.2481 \\
\hline $\mathrm{NO}$ & 39.3722 & 65.6203 & 26.2481 \\
\hline $\mathrm{NO}_{2}$ & 39.3722 & 65.6203 & 26.2481 \\
\hline \multicolumn{4}{|c|}{ Volatile Feed to Vapor Space: } \\
\hline $\mathrm{H}_{2} \mathrm{O}$ & \multicolumn{3}{|c|}{$8,612.5536$} \\
\hline $\mathrm{HCOOH}$ & \multicolumn{3}{|c|}{40.9465} \\
\hline $\mathrm{C}_{2} \mathrm{H}_{4} \mathrm{O}_{3}$ & \multicolumn{3}{|c|}{87.6567} \\
\hline
\end{tabular}


SRNL-STI-2011-00321

Revision 0

Table 4-5. 4-Stage Cold Cap Model Input for the Sugar Flowsheet Feed at the DWPF Design Basis Glass Production Rate of $228 \mathrm{lb} / \mathrm{hr}$.

\begin{tabular}{|c|c|c|c|}
\hline Species & Stage 1 & Stage 2 & Stage 3 \\
\hline & gmole $/ \mathrm{hr}$ & gmole $/ \mathrm{hr}$ & gmole $/ \mathrm{hr}$ \\
\hline \multicolumn{4}{|c|}{ Non-Volatile Feed: } \\
\hline $\mathrm{Al}_{2} \mathrm{O}_{3}$ & 0 & 113.7286 & 0 \\
\hline $\mathrm{B}_{2} \mathrm{O}_{3}$ & 76.0578 & 0 & 0 \\
\hline $\mathrm{CaO}$ & & 1.0233 & 0 \\
\hline $\mathrm{CuO}$ & 1.6257 & 0 & 0 \\
\hline $\mathrm{Fe}_{2} \mathrm{O}_{3}$ & 70.26807 & 0 & 0 \\
\hline $\mathrm{K}_{2} \mathrm{O}$ & 0.26817 & 0 & 0 \\
\hline $\mathrm{Li}_{2} \mathrm{O}$ & 0 & 177.2137 & 0 \\
\hline $\mathrm{MgO}$ & 0 & 0 & 7.1063 \\
\hline $\mathrm{MnO}_{2}$ & 0 & 22.7362 & 0 \\
\hline $\mathrm{MnO}$ & 20.8583 & 0 & 0 \\
\hline $\mathrm{Na}_{2} \mathrm{O}$ & 132.3724 & 85.4331 & 0 \\
\hline $\mathrm{NiO}$ & 17.5960 & 0 & 0 \\
\hline $\mathrm{SiO}_{2}$ & 839.5050 & 0 & 0 \\
\hline $\mathrm{CaSO}_{4}$ & 0 & 0 & 4.1665 \\
\hline $\mathrm{Na}_{2} \mathrm{SO}_{4}$ & 0 & 0 & 1.2711 \\
\hline carbon & 103.1957 & 171.9929 & 68.7971 \\
\hline $\mathrm{H}_{2} \mathrm{O}$ & 814.4250 & 78.8301 & 0 \\
\hline $\mathrm{CO}$ & 0 & 27.7291 & 0 \\
\hline $\mathrm{CO}_{2}$ & 0 & 27.7291 & 0 \\
\hline $\mathrm{H}_{2}$ & 27.7292 & 0 & 0 \\
\hline $\mathrm{O}_{2}$ & 37.9906 & 63.3176 & 25.3270 \\
\hline NO & 38.6276 & 64.3794 & 25.7517 \\
\hline $\mathrm{NO}_{2}$ & 38.6276 & 64.3794 & 25.7517 \\
\hline \multicolumn{4}{|c|}{ Volatile Feed to Vapor Space: } \\
\hline $\mathrm{H}_{2} \mathrm{O}$ & \multicolumn{3}{|c|}{$10,660.9358$} \\
\hline $\mathrm{HCOOH}$ & \multicolumn{3}{|c|}{26.0953} \\
\hline
\end{tabular}

\subsection{Analysis of DM10 Data}

There are two key unknowns yet to be determined from the DM10 data before any assessment on the off-gas flammability potential can be made. Since the melter was run slightly under vacuum at -1 " $\mathrm{H}_{2} \mathrm{O}$, it was unavoidable to have ambient air leaked into the DM10 either passively through its crevices or actively through the dilution air damper in addition to the passive route. This leaked air lowers the vapor space temperature and also acts as both combustion and dilution air. Furthermore, the combustion kinetics is determined not by the measured vapor space temperature but by the actual gas temperature measured without the interference of thermal radiation, which is difficult to do. In this work, both the rate of total DM10 air inleakage and the vapor space gas temperature were calculated by performing careful mass and energy balance calculations using steady state data.

\subsection{Selection of Steady State Data}

The entire DM10 data sent by the VSL were scanned to identify those time segments during which the standard deviation of the average temperature readings from two exposed vapor space thermocouples (TT-03 and TT-05) remained less than $5{ }^{\circ} \mathrm{C}$ at each $50{ }^{\circ} \mathrm{C}$ temperature increment. The TT-03 and TT-05 readings were taken at two different elevations, 2" and 5" from the ceiling, 
respectively. A total of 25 steady state periods lasting from 32 to 92 minutes were selected for all six melter runs, and some of the key data used in the mass and energy balance calculations of each steady state are summarized in Appendix A. In 4 of those 25 steady state periods selected, the standard deviation of the average vapor space temperature readings was actually greater than the criterion of $5{ }^{\circ} \mathrm{C}$ or less; however, they were still included due to lack of steady state data particularly for the bubbled baseline and both the bubbled and non-bubbled glycolic flowsheet feed runs. The vapor space temperature readings taken from a thermowell (TT-04) were not used since its response time was not fast enough to generate any meaningful number of steady state data sets with a limited supply of feed.

Although Appendix A lists the $\mathrm{H}_{2}$ data taken using both the $\mathrm{GC}$ and the sensor, the former generated data every 5 minutes or so, compared to every 25 seconds for the latter. So, it was the $\mathrm{H}_{2}$ data taken using the sensor that were used in the analysis; the GC data were only used either when no sensor data were available or to cross-check the sensor data. As shown in Appendix A, the standard deviations of both temperature and flow readings were reasonably low for most of the steady state data selected; however, this was not the case with the $\mathrm{H}_{2}$ and $\mathrm{CO}$ readings. The standard deviation of the $\mathrm{H}_{2}$ readings ranged from 11 to $26 \%$ of the mean, while that of the $\mathrm{CO}$ readings ranged from 10 to $47 \%$ of the mean.

\subsection{Mass and Energy Balance}

A schematic of the DM10 sampling locations is shown in Figure 5-1. The film cooler air was preheated to $\sim 246{ }^{\circ} \mathrm{C}$ (TT-40) and its flow rate was fixed at $15 \mathrm{sfcm}$ throughout the test. The temperature of cooled off-gas was measured at the film cooler exit (TT-07) and again at the exit of the Transition Line (TT-50). The off-gas flow and composition were measured at the same location as TT-50.

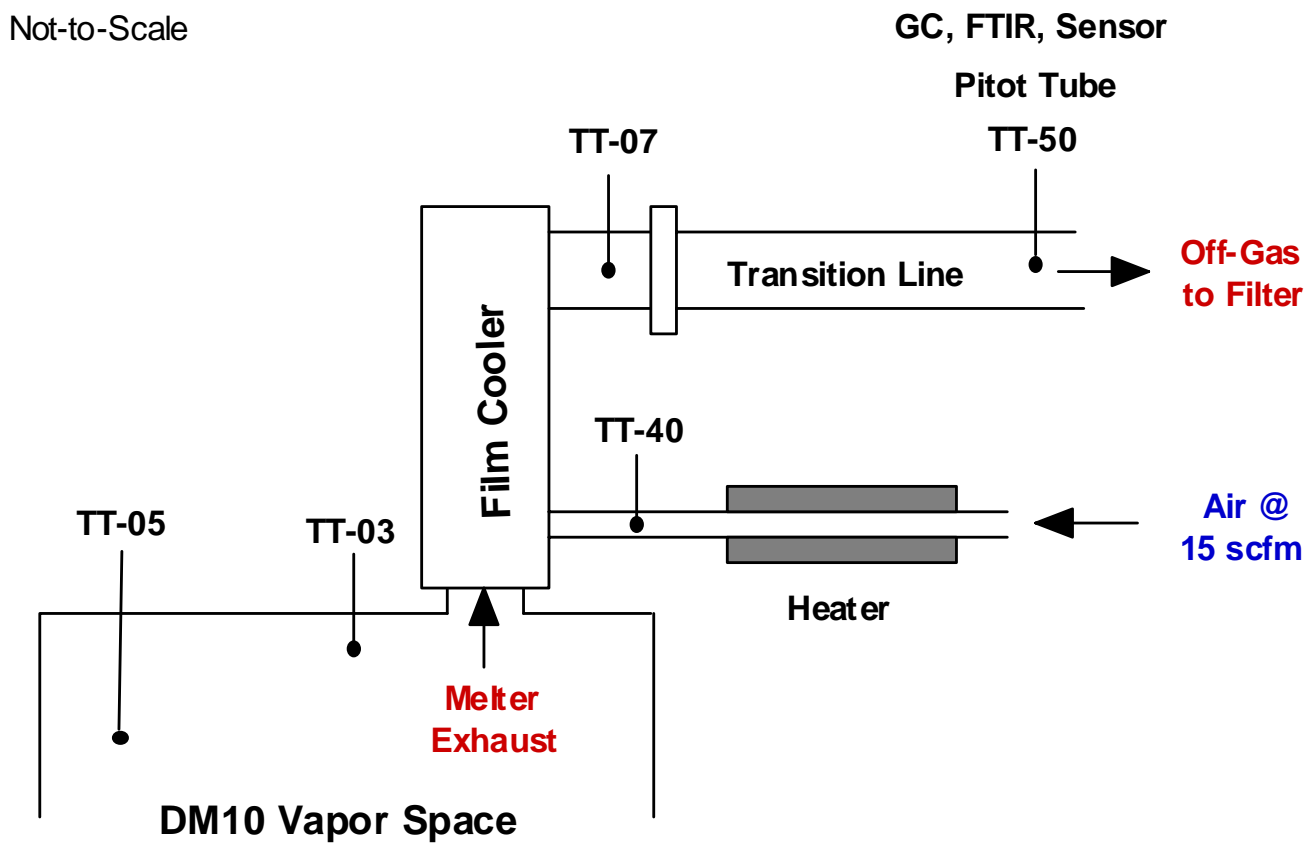

Figure 5-1. Schematic of DM10 Sampling Locations. 
The mass and energy balance equations were set up based on the following assumptions:

- The DM10 vapor space was perfectly mixed - a Continuous Stirred Tank Reactor (CSTR).

- The thermal state of the DM10 vapor space was represented by the average of the two measured temperatures (TT-03 and TT-05).

- There was no heat loss in the film cooler.

- There was no air inleakage downstream of the DM10.

- The stack flow readings were obtained on a dry basis.

Specifically, the rate of DM10 air inleakage and its vapor space gas temperature were solved iteratively by matching; (1) the calculated off-gas temperature at the film cooler exit with TT-07 readings and (2) off-gas flow downstream of the film cooler with the stack flow readings in dsfem taken at TT-50. The results of the DM10 mass and energy balances are given in Table 5-1. The estimated passive air inleakage rates with the dilution air damper closed ranged from 1.4 to 3.8 scfm during the non-bubbled baseline and non-bubbled glycolic flowsheet feed runs, respectively. As expected, the total air inleakage rate increased as the measured vapor space temperature decreased, since more and more air was allowed to leak in by gradually increasing the opening of the dilution air damper. The calculated stack flows in scfm and dscfm were in good agreement with their respective data regardless of feed type or mode of operation. However, the calculated stack flows in afcm were considerably higher than the data except for the baseline feed.

A significantly higher degree of irregularities was found in the temperature data. First, two out of the three steady state data points selected for the non-bubbled baseline feed run resulted in $\Delta \mathrm{T}$ 's of 231 and $352{ }^{\circ} \mathrm{C}$, both of which are considerably greater than those predicted by Eq. (13). This was unfortunate, since together with the data taken at $290{ }^{\circ} \mathrm{C}$ measured vapor space temperature these data could have been used to validate the cold cap and off-gas combustion models, which were developed specifically for the baseline formic acid flowsheet feeds. By contrast, the calculated $\Delta T$ 's for two out of the four steady state data points selected for the non-bubbled glycolic feed run were 0 and $17{ }^{\circ} \mathrm{C}$. These unrealistically small $\Delta \mathrm{T}$ 's were a direct result of seemingly-high TT-07 readings.

Moreover, it was noted during the bubbled glycolic feed run that the thermocouple that feeds TT07 was not in a fully-inserted position; when it was fully inserted, the TT-07 readings went up by $17^{\circ} \mathrm{C} .^{2}$ In Table 5-1, two sets of results are given for each of the three bubbled glycolic feed runs at the measured vapor space temperatures of 442,385 and $320{ }^{\circ} \mathrm{C}$. The first set of these results is based on the actual TT-07 data taken before the thermocouple was re-seated, while the second set was generated by effectively adding $17{ }^{\circ} \mathrm{C}$ to the indicated TT- 07 data. The resulting $\Delta \mathrm{T}$ 's of the second set were significantly smaller than their counterparts of the first set, which in turn made the estimated gas temperatures go up by $35-75^{\circ} \mathrm{C}$. As a result, the gas temperatures of the second set are now shown to decrease with decreasing vapor space temperature, as they should, which was not the case for the first set. Despite these improvements, the across-the-board adjustment rendered the resulting TT-07 data somewhat arbitrary and, therefore, they are not suitable for the extraction of kinetic parameters.

On the other hand, the calculated $\Delta \mathrm{T}$ 's for both bubbled and non-bubbled sugar flowsheet feed runs were all within the expected ranges despite the fact that some of the data points did not quite follow the general trend of decreasing $\Delta \mathrm{T}$ with decreasing temperature. As a result, the estimated vapor space gas temperatures of the sugar flowsheet feed runs should be more consistent with the measured data than those of either the baseline or glycolic flowsheet feed runs. 
Table 5-1. Results of Steady State Mass and Energy Balance of DM10 Runs.

\begin{tabular}{|c|c|c|c|c|c|c|c|c|}
\hline Feed & $\begin{array}{l}\text { Op. } \\
\text { Mode }\end{array}$ & $\begin{array}{l}\text { Duration } \\
\text { (hh:mm:ss) }\end{array}$ & $\begin{array}{l}\text { Dilution } \\
\text { Air } \\
\text { Damper }\end{array}$ & $\begin{array}{c}\text { Average } \\
\text { VS Temp } \\
\left({ }^{\circ} \mathrm{C}\right)\end{array}$ & $\begin{array}{l}\Delta \mathrm{T} \\
\left({ }^{\circ} \mathrm{C}\right)\end{array}$ & $\begin{array}{l}\text { VS Gas } \\
\text { Temp } \\
\left({ }^{\circ} \mathrm{C}\right)\end{array}$ & $\begin{array}{l}\text { Total Air } \\
\text { Inleakage } \\
\text { (scfm) }\end{array}$ & $\begin{array}{c}\text { Carbon } \\
\text { Balance } \\
(\%)\end{array}$ \\
\hline Baseline & NB & 1:00:01 & Closed & 483.68 & 352.24 & 131.44 & 1.3569 & -18.37 \\
\hline " & 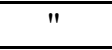 & $1: 22: 02$ & " & 373.16 & 230.72 & 142.44 & 1.7111 & -33.21 \\
\hline$"$ & $"$ & 1:00:29 & Open & 296.22 & 105.86 & 190.36 & 12.0629 & -9.26 \\
\hline$"$ & $\mathrm{~B}$ & $0: 48: 02$ & Closed & 473.44 & 167.07 & 306.37 & 1.8983 & -22.74 \\
\hline$"$ & $"$ & $1: 22: 02$ & " & 409.81 & 173.18 & 236.63 & 1.8588 & -7.33 \\
\hline$"$ & $"$ & 1:02:01 & Open & 334.39 & 123.95 & 210.45 & 11.6616 & -17.07 \\
\hline Glycolic & NB & $1: 32: 29$ & Closed & 471.22 & 0.00 & 471.22 & 3.7508 & -22.63 \\
\hline " & $"$ & 1:22:02 & Open & 423.21 & 17.50 & 405.71 & 3.8980 & -27.77 \\
\hline$"$ & $"$ & 1:00:01 & $"$ & 374.24 & 131.75 & 242.49 & 9.7733 & -24.37 \\
\hline$"$ & $"$ & 1:06:33 & $"$ & 323.17 & 108.45 & 214.73 & 11.7926 & -20.39 \\
\hline$"$ & B & 0:36:00 & $"$ & 441.84 & 243.21 & 198.63 & 2.8463 & -16.76 \\
\hline$"$ & $"$ & " & $"$ & " & 169.24 & 272.60 & 2.8463 & " \\
\hline$"$ & $"$ & 1:04:27 & $"$ & 385.04 & 180.59 & 204.44 & 5.7286 & -27.57 \\
\hline$"$ & $"$ & " & $"$ & " & 128.93 & 256.11 & 5.7287 & " \\
\hline$"$ & $"$ & 0:40:00 & $"$ & 319.69 & 145.66 & 174.03 & 12.4840 & -18.69 \\
\hline$"$ & $"$ & " & $"$ & " & 110.53 & 209.16 & 12.4840 & " \\
\hline$"$ & $"$ & $1: 16: 07$ & $"$ & 257.00 & 76.55 & 180.45 & 15.4104 & -17.82 \\
\hline Sugar & NB & $1: 25: 34$ & Closed & 503.85 & 113.33 & 390.52 & 3.4326 & -24.38 \\
\hline$"$ & $"$ & 0:32:00 & " & 499.11 & 135.81 & 363.30 & 3.6537 & -12.95 \\
\hline$"$ & $"$ & $0: 52: 00$ & $"$ & 474.31 & 139.75 & 334.56 & 3.5423 & -3.78 \\
\hline$"$ & " & 1:08:00 & Open & 428.24 & 131.22 & 297.02 & 6.3503 & -14.82 \\
\hline$"$ & $"$ & $0: 42: 01$ & $"$ & 374.79 & 130.18 & 244.60 & 7.8559 & -14.18 \\
\hline$"$ & $"$ & $1: 18: 33$ & $"$ & 331.66 & 128.82 & 202.85 & 10.9614 & -9.79 \\
\hline$"$ & $"$ & 1:08:01 & $"$ & 241.44 & 78.51 & 162.93 & 17.1985 & -0.75 \\
\hline$"$ & B & $0: 57: 55$ & $"$ & 526.57 & 80.60 & 445.97 & 3.0286 & -18.29 \\
\hline$"$ & $"$ & 0:28:00 & $"$ & 428.12 & 62.16 & 365.97 & 3.9201 & -13.24 \\
\hline$"$ & $"$ & $1: 28: 55$ & $"$ & 336.79 & 121.91 & 214.88 & 14.3927 & 0.50 \\
\hline$"$ & $"$ & $1: 14: 30$ & $"$ & 257.93 & 66.63 & 191.30 & 18.7623 & -1.70 \\
\hline
\end{tabular}

$\mathrm{NB}=$ non-bubbled operation; $\mathrm{B}=$ bubbled operation; $\Delta \mathrm{T}=$ measured - true gas temperature of DM10 vapor space; \% Carbon Balance $=($ calculated - measured carbon flows $) /$ measured carbon flow* 100

Table 5-1 also shows the results of carbon balance; a given percent carbon balance represents the difference between the calculated and measured (as $\mathrm{CO}$ and $\mathrm{CO}_{2}$ ) carbon flows divided by the measured carbon flow. It is interesting to note that the carbon balance was negative in all but one steady state runs, which means that the measured carbon flows were greater than those calculated. The carbon flow was calculated from the measured TOC and feed rate, the latter of which was in turn calculated as the one-hour moving average of the rates of feed tank weight change. Therefore, unless the carbon species are extensively segregated in the feed causing irregularities in the TOC feed rate, a negative carbon balance simply means that more $\mathrm{CO}$ and $\mathrm{CO}_{2}$ were produced than fed, which is an indication that steady state conditions were not maintained. Furthermore, if there had been segregation of carbon, it would mostly likely have occurred in the sugar flowsheet feed, since high solubilities of the formate and glycolate salts would have prevented segregation from occurring in either the baseline or glycolic flowsheet feed. Clearly, this was not the case; the sugar flowsheet feed exhibited the most consistent carbon balance of all three feeds. By contrast, the carbon balance for most of the baseline and glycolic acid flowsheet feed runs remained poor, 
ranging from -17 to $-33 \%$. Therefore, the large carbon imbalances seen in Table 5-1 are likely to have resulted from the "unsteady" nature of data.

The calculated DM10 vapor space gas temperatures in Table 5-1 are plotted against the measured vapor space temperature in Figure 5-2. Since most of the DM10 runs were made at below $500{ }^{\circ} \mathrm{C}$, the impact of thermal radiation should be less than that predicted by Eq. (13), which was derived from the data taken mostly at above $500{ }^{\circ} \mathrm{C}$. Figure $5-2$ shows that this was indeed the case; most of the data points stay close to or above the solid line predicted by Eq. (13). Furthermore, a dotted line is drawn to qualitatively show the reduced impact of thermal radiation at below $500{ }^{\circ} \mathrm{C}$; as expected, it appears to represent the calculated gas temperatures better. Several data points that stay considerably above or below either line are clearly the outliers, and the integrity of the DM10 data associated with these outliers must be called into question.

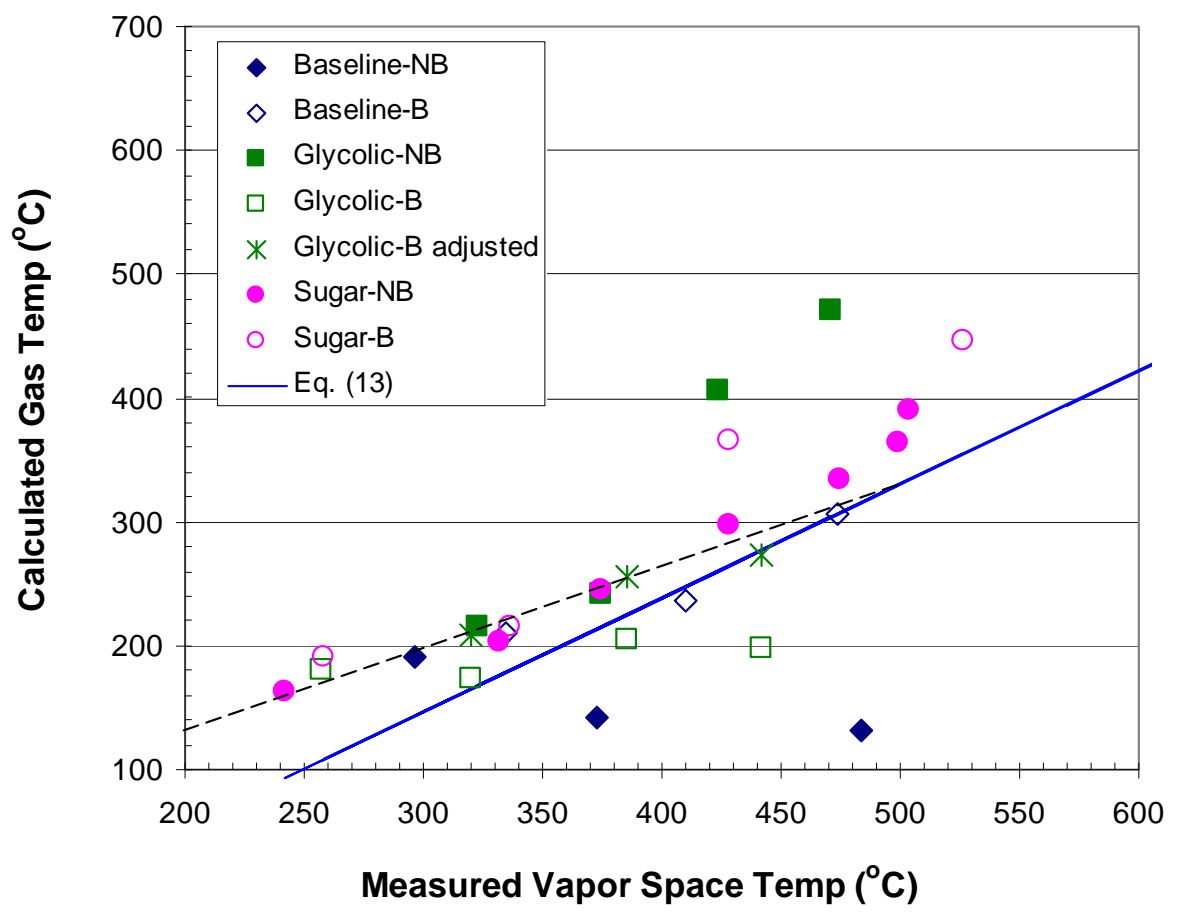

Figure 5-2. Measured vs. Calculated Gas Temperature in DM10 Vapor Space.

The impact of thermal radiation on the gas temperature or $\Delta \mathrm{T}$ is plotted in Figure 5-3 against the measured vapor space temperature during all six DM10 runs. The calculated $\Delta \mathrm{T}$ 's are shown to converge at temperatures below $\sim 340{ }^{\circ} \mathrm{C}$ but increasingly diverge in the direction of increasing temperature above $\sim 340{ }^{\circ} \mathrm{C}$. Since the total air inleakage is inversely proportional to the vapor space temperature as explained earlier, the trend shown in Figure 5-4 between calculated $\Delta \mathrm{T}$ vs. total air inleakage is almost the mirror image of that in Figure 5-3; it diverges in the direction of decreasing total air inleakage rate. The dilution factor, which is defined here as the film cooler air flow-to-melter exhaust ratio, was as high as 7.4 with no dilution air addition during hightemperature baseline feed runs and as low as 0.7 when the dilution air damper was opened during low-temperature sugar feed runs. It may be postulated that as the air inleakage rate decreases (or as the dilution factor increases), the TT-07 readings become less sensitive to the changes in the melter exhaust temperature since the film cooler air flow becomes more dominating. As a result, any small variations in the TT-07 readings will be magnified in the resulting $\Delta \mathrm{T}$ 's, thus leading to larger variations as shown in Figure 5-4. 


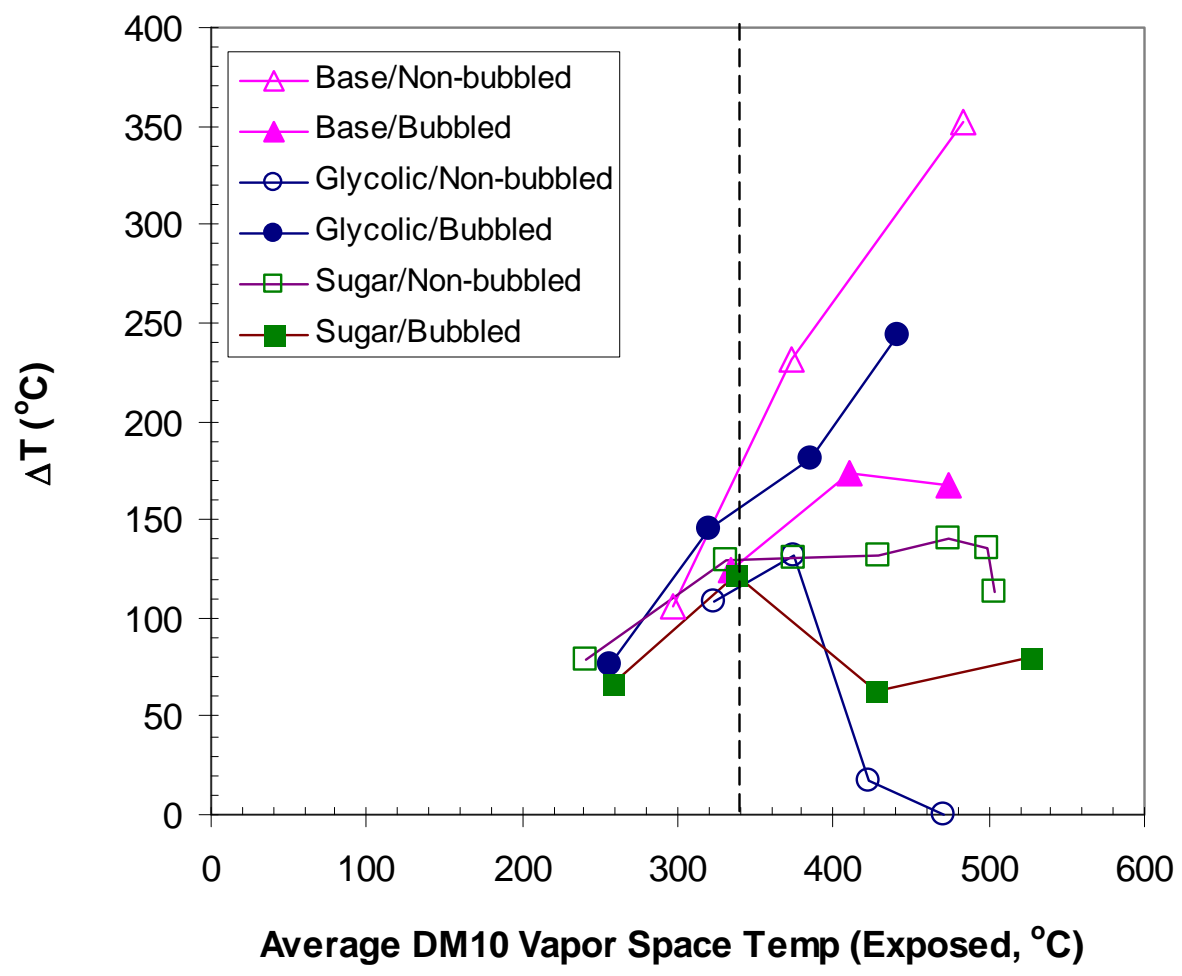

Figure 5-3. Measured Vapor Space Temperature vs. $\Delta T$ during DM10 Runs.

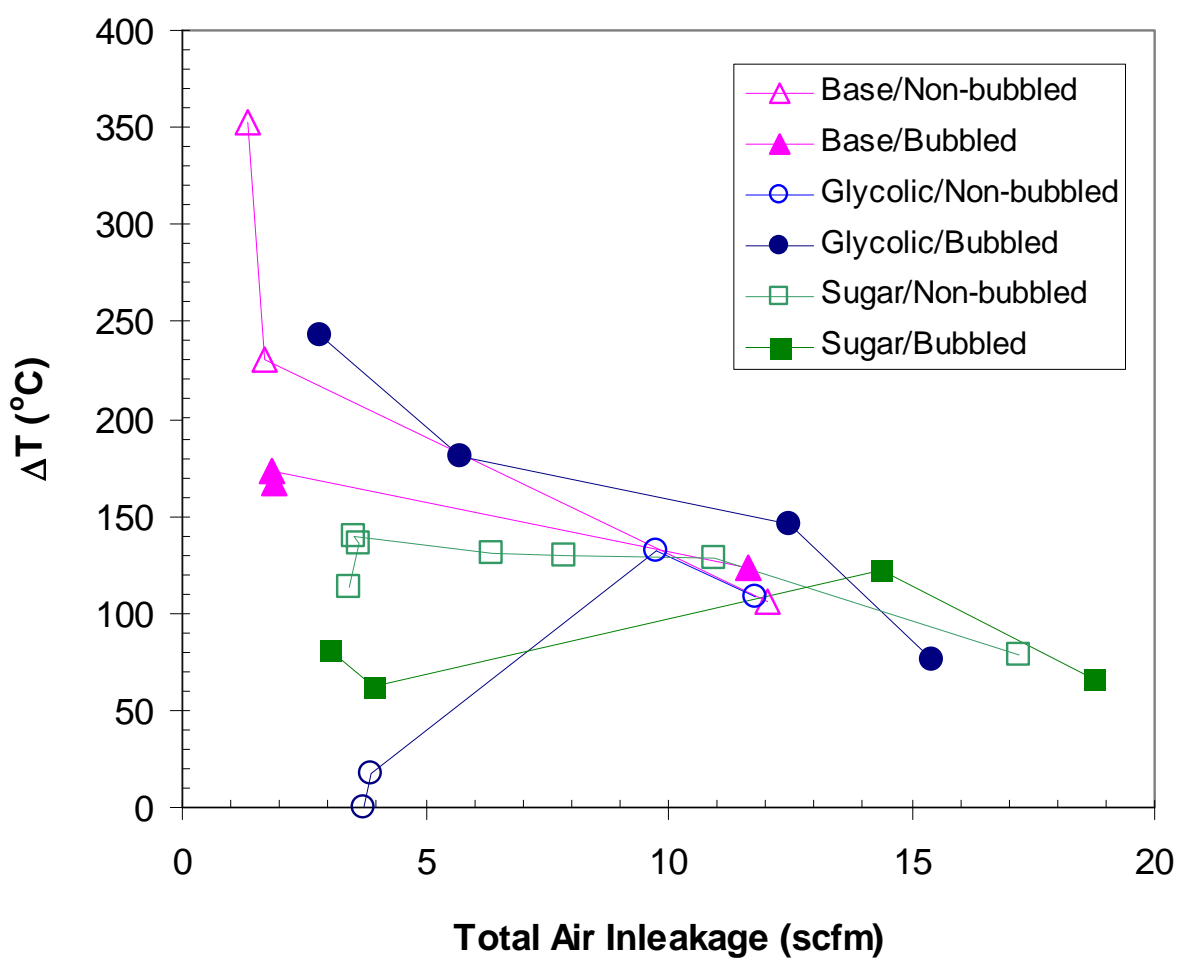

Figure 5-4. Total Air Inleakage vs. $\Delta T$ during DM10 Runs. 


\subsection{Model Development, Adjustment and Validation}

Once the rate of DM10 air inleakage and the true vapor space gas temperature are determined, off-gas data can be analyzed with the aid of models. Since the existing cold cap and vapor space combustion models were developed using the formic acid flowsheet data, the model predictions can only be validated against the data taken with the baseline feed. Of the six baseline feed data sets, only those taken at the lowest measured vapor space temperatures of 296 and $334{ }^{\circ} \mathrm{C}$ for the non-bubbled and bubbled runs, respectively, were used. Table 5-1 shows that the calculated $\Delta \mathrm{T}^{\prime} \mathrm{s}$ at 296 and $334{ }^{\circ} \mathrm{C}$ were 106 and $124{ }^{\circ} \mathrm{C}$, respectively, both of which are well within the expected range; their estimated gas temperatures are shown to be close to the dotted line in Figure 5-2.

However, the results of charge balance in Table 4-2 showed that all three DM10 feeds contained varying concentrations of free formic acid, which would boil off upon entering the melter and decompose in the vapor space supposedly via Eq. (11) according to the literature and, to a lesser extent, via Eq. (12). Therefore, before the existing cold cap model can be validated against the baseline feed data, a model for the gaseous formic acid decomposition must be developed first which can predict the extent of formic acid decomposition and subsequent formation of $\mathrm{CO}$ and $\mathrm{H}_{2}$. The $\mathrm{CO}$ and $\mathrm{H}_{2}$ thus formed are added to their respective cold cap contributions in the melter exhaust, which would then enable comparison to the off-gas data taken at the Transition Line exit.

\subsection{Model Development and Adjustment}

The off-gas data taken during the non-bubbled sugar feed run formed the basis for developing the gaseous formic acid decomposition model, since; (1) the run produced the most number of steady state data points at seven and the calculated $\Delta \mathrm{T}$ 's were all well within the expected range. The carbon balance was also good ranging from -1 to $-15 \%$ except for the one data point taken at the highest vapor space temperature. The run also produced off-gas data taken at the lowest vapor space gas temperature of $163{ }^{\circ} \mathrm{C}$ of all 25 steady state data points whose $\Delta \mathrm{T}$ 's fell within the expected range. One key assumption made was:

- Formic acid volatilizes at $100.8^{\circ} \mathrm{C}$ but remains un-decomposed until $\mathrm{T}_{\text {gas }}=163{ }^{\circ} \mathrm{C}$.

The validity of this assumption is supported by the results of an earlier work, ${ }^{14}$ in which formic acid vapor was passed through various glass tubes heated in a furnace and the amount of gas evolution was measured at varying temperatures, as shown in Figure 6-1. It is clearly seen that formic acid did not decompose to any appreciable extent until $\mathrm{T}_{\text {gas }}=\sim 250{ }^{\circ} \mathrm{C}$ in the simple test system. Since surface irregularities as well as impurities such as alumina are known to increase the decomposition rate, ${ }^{15}$ the potential for catalytic decomposition certainly existed in the DM10 vapor space and, therefore, it is likely that formic acid began to decompose at lower temperatures than in the glass tubes.

Several rate expressions have been proposed in literature for the two competing decomposition paths of gaseous formic acid. ${ }^{9,16}$ However, a direct application of those rate expressions to this work seems implausible, since the test conditions under which they were derived are markedly different from those of the DM10 runs, including the concentration of formic acid, temperature and the degree of system complexity such as the potential sources for catalytic reactions. In the presence of abundant air and steam, the concentration of formic acid in the DM10 vapor space was estimated to be no higher than $0.5 \%$. Figure $6-2$ shows that the overall rate of formic acid decomposition not only increases with increasing concentration of formic acid given in terms of its partial pressure in $\mathrm{mmHg}$ but its rate of increase becomes higher with increasing temperature, although they appear to merge closer at the low concentration range comparable to that of the DM10. ${ }^{16}$ It was also observed that the first-order rate constant ratio of $k_{1} / k_{2}$ as defined in Eqs. (11) 


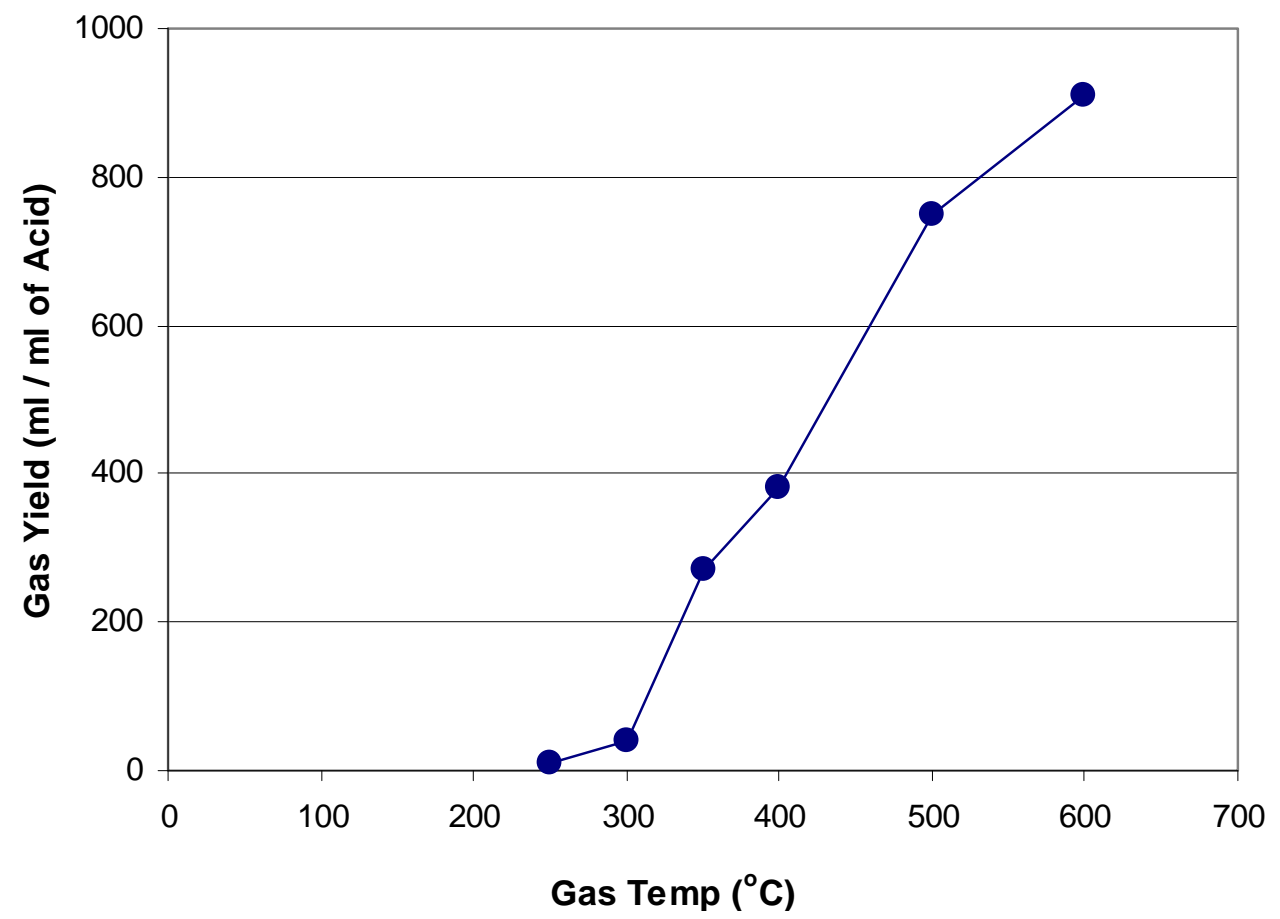

Figure 6-1. Gas Yield from Formic Acid Decomposition in Pyrex Glass Tube. ${ }^{14}$

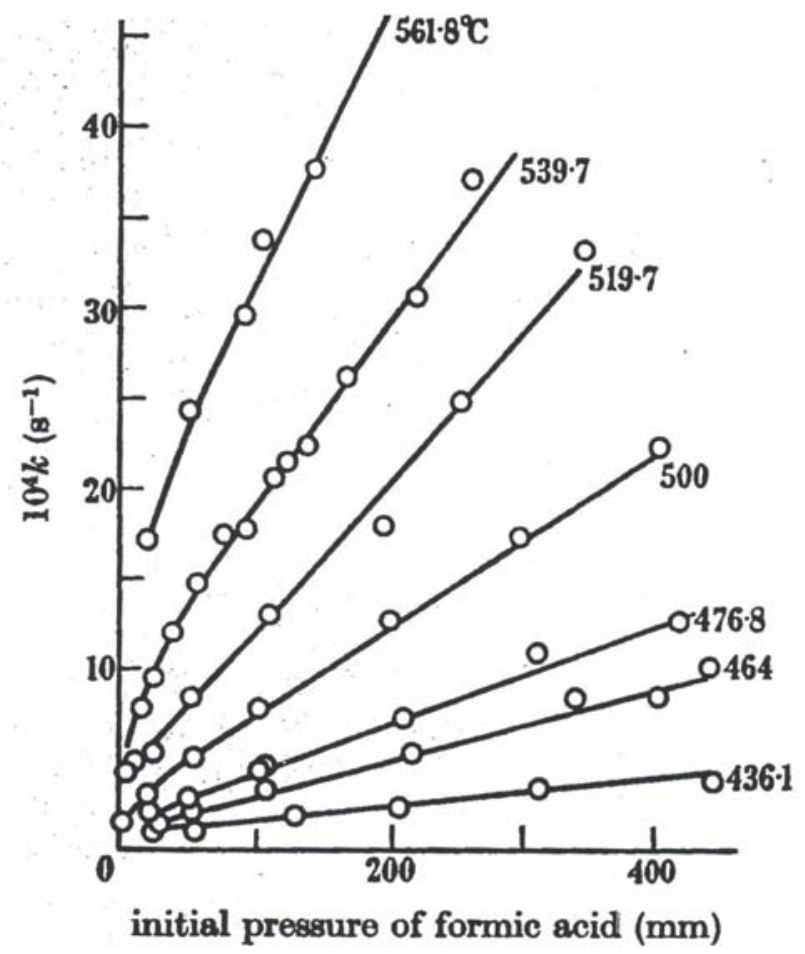

Figure 6-2. Overall Rate Constant of Formic Acid Decomposition at Varying Concentration and Temperature-taken from Ref. [16]. 
and (12) decreases with increasing temperature. ${ }^{9}$ Since the $k_{1} / k_{2}$ ratio is equivalent to the $\mathrm{CO} / \mathrm{CO}_{2}$ ratio, it means that the rate of increase in $\mathrm{CO}_{2}$ is greater than that of $\mathrm{CO}$ as temperature is increased, which in turn means that the fraction of decomposed formic acid via the dehydration route decreases with increasing temperature. Once developed, the validity of the resulting formic acid decomposition model will be checked against these trends reported in the literature.

\subsubsection{Adjustment of Cold Cap Model for Sugar Flowsheet Feed}

The compositions of the calcine gases and glass predicted by the cold cap model for the sugar flowsheet feed are compared in Table 6-1 against measured off-gas data and glass redox potential in terms of iron valence ratio. The off-gas data were taken during the non-bubbled run at $241{ }^{\circ} \mathrm{C}$ measured vapor space temperature or $\mathrm{T}_{\text {gas }}=163{ }^{\circ} \mathrm{C}$. Since the focus of this work was on the assessment of off-gas flammability potential, the scope of model adjustment was limited to the flammable off-gas components only. It is seen that the model over predicted both $\mathrm{H}_{2}$ and $\mathrm{CO}$ concentrations by a factor of 3 to 4 , while it under predicted the measured glass redox ratio in closed crucibles. It means that excess $\mathrm{O}_{2}$ was retained in glass and, as a result, there was not enough $\mathrm{O}_{2}$ left to further oxidize $\mathrm{H}_{2}$ and $\mathrm{CO}$ in the cold cap, thus rendering the resulting calcine gases more flammable

Table 6-1. Sugar Feed Data vs. Cold Cap Model Predictions (per $1.28 \mathrm{~kg} / \mathrm{hr}$ Feed Rate).

\begin{tabular}{|c|c|c|c|}
\hline DM10 Sugar Feed@0.875 Sugar Ratio & $\begin{array}{c}\text { Data by } \\
\text { VSL }\end{array}$ & $\begin{array}{l}\text { Data by } \\
\text { SRNL }\end{array}$ & $\begin{array}{c}\text { Cold Cap } \\
\text { Model }\end{array}$ \\
\hline \multicolumn{4}{|l|}{ Calcine Gases: } \\
\hline \begin{tabular}{l|l} 
& $\mathrm{H}_{2}(\mathrm{~kg} / \mathrm{hr})$ \\
\end{tabular} & 0.00016 & - & 0.00051 \\
\hline $\mathrm{CO}(\mathrm{kg} / \mathrm{hr})$ & 0.00051 & - & 0.00199 \\
\hline molar $\mathrm{CO} / \mathrm{CO}_{2}$ & 0.00744 & - & 0.04854 \\
\hline molar $\mathrm{H}_{2} /\left(\mathrm{CO}+\mathrm{CO}_{2}\right)$ & 0.03206 & - & 0.16708 \\
\hline \multicolumn{4}{|l|}{ Glass: } \\
\hline $\mathrm{Fe}^{2+} / \mathrm{Fe}^{\text {total }}$ (mole/mole) & $0.143^{*}$ & - & 0.132 \\
\hline
\end{tabular}

* Interpolated from redox data taken at different sugar ratios. ${ }^{\#}$ No data since sugar was added at VSL.

When the cold cap model results were forced to match the data by converting $\mathrm{CO}$ and $\mathrm{H}_{2}$ into $\mathrm{CO}_{2}$ and $\mathrm{H}_{2} \mathrm{O}$, respectively, the required $\mathrm{O}_{2}$ for the conversion was determined to be $0.0037 \mathrm{~kg} / \mathrm{hr}$ per $1.28 \mathrm{~kg} / \mathrm{hr}$ feed rate, which far exceeded the excess $\mathrm{O}_{2}$ that would have been made available by forcing the predicted glass redox to match its respective data via Eq. (17):

$$
2 \mathrm{Fe}^{3+}+\mathrm{O}^{2-} \rightarrow 2 \mathrm{Fe}^{2+}+1 / 2 \mathrm{O}_{2}
$$

It means that the model is not internally consistent with data. Since the carbon balance of the nonbubbled sugar flowsheet feed data taken at $\mathrm{T}_{\text {gas }}=163{ }^{\circ} \mathrm{C}$ was excellent as shown in Table 5-1, this "broken" internal consistency of the model is likely due to the incompatibility of the existing cold cap model construct with the sugar flowsheet feed. At the same time, however, it may also have been caused in part by incompatible oxidant and reductant data used to build the SRAT product, which subsequently made the resulting off-gas more flammable than the resulting glass was oxidizing. A supporting evidence for this postulation comes from the fact that all IC data except for the formate were taken from the AD Repeat analysis, while the formate was taken from the PSAL analysis simply because it resulted in a better charge balance. To put things in perspective, the aforementioned $\mathrm{O}_{2}$ deficit of $0.0037 \mathrm{~kg} / \mathrm{hr}$ is equivalent to $0.04 \%$ of the total air inleakage estimated for that run. 


\subsubsection{Development of Formic Acid Decomposition Model}

Since the cold cap model already over predicted the measured $\mathrm{CO}$ and $\mathrm{H}_{2}$ data at $\mathrm{T}_{\text {gas }}=163{ }^{\circ} \mathrm{C}$ as shown in Table 6-1, there was no need to turn on the formic acid decomposition only to produce additional excess $\mathrm{CO}$ and $\mathrm{H}_{2}$. Therefore, the assumption stated earlier that formic acid remains un-decomposed until $\mathrm{T}_{\text {gas }}=163{ }^{\circ} \mathrm{C}$ is consistent with the data. Instead, it was the over predicted $\mathrm{CO}$ and $\mathrm{H}_{2}$ that were adjusted down to match their respective data, and the adjusted $\mathrm{CO}$ and $\mathrm{H}_{2}$ flows were used as the source terms for the remaining non-bubbled sugar feed runs. The fraction of formic acid decomposed and that of decomposed formic acid via the dehydration route were then found iteratively by matching the calculated $\mathrm{H}_{2}$ and $\mathrm{CO}$ concentrations with the data taken at the Transition Line exit at each successively higher gas temperatures above $163{ }^{\circ} \mathrm{C}$. The resulting formic acid decomposition fractions are shown in Figure 6-3.

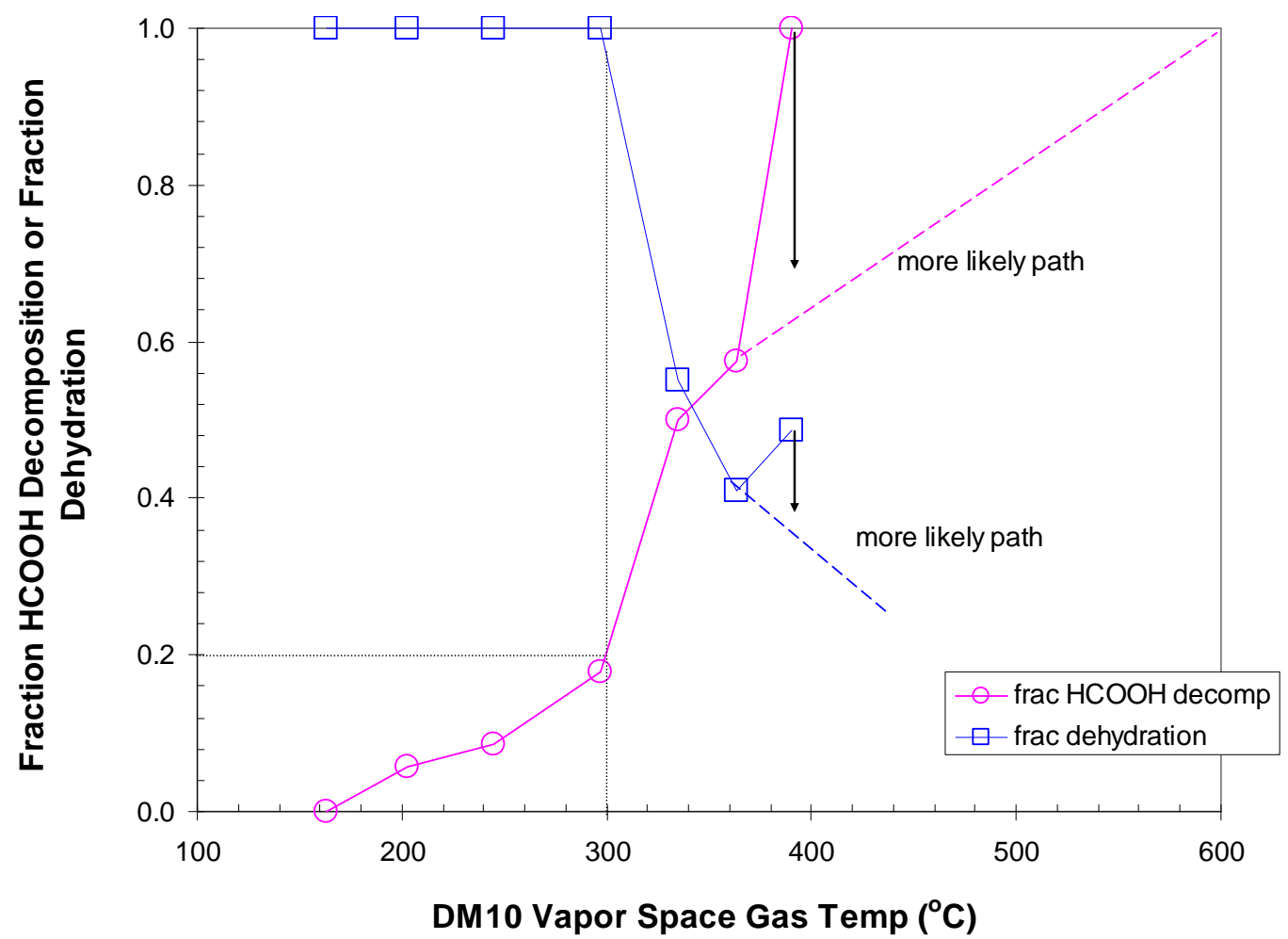

Figure 6-3. Formic Acid Decomposition and Dehydration Fractions during Non-Bubbled Sugar Feed Runs.

As stated earlier, the decomposition of formic acid was assumed to begin at $\mathrm{T}_{\text {gas }}=163{ }^{\circ} \mathrm{C}$. At 250 ${ }^{\circ} \mathrm{C}, \sim 10 \%$ of the free formic acid in the sugar flowsheet feed is shown to decompose, and this is much higher than that shown in Figure 6-1, which was measured in a considerably simpler system containing just formic acid in a smooth pyrex glass tube. A higher rate of decomposition in the DM10 vapor space was expected, since the surface irregularities as well as impurities such as alumina, titania and nickel are all known to increase the rate. ${ }^{15}$ By $300{ }^{\circ} \mathrm{C}, 20 \%$ of the free formic acid is shown to decompose but still via the dehydration route only, which is in agreement with the general consensus in the literature that the dehydration reaction via Eq. (11) is the dominant route for the homogeneous gas-phase decomposition of formic acid. ${ }^{9}$ 
As the temperature increases above $300{ }^{\circ} \mathrm{C}$, the rate of decomposition is shown to accelerate and the fraction of decomposed formic acid via the dehydration route begins to decrease sharply, which means that according to Eqs. (11) and (12) the decomposition product ratio of $\mathrm{CO} / \mathrm{CO}_{2}$ decreased with increasing temperature. Since the $\mathrm{CO} / \mathrm{CO}_{2}$ ratio is equivalent to the rate constant ratio $\mathrm{k}_{1} / \mathrm{k}_{2}$, it can be said that the $\mathrm{k}_{1} / \mathrm{k}_{2}$ ratio also decreased with increasing temperature or the inverse ratio $\mathrm{k}_{2} / \mathrm{k}_{1}$ increased with increasing temperature. The latter is indeed the same qualitative trend measured experimentally, although the temperature range was much higher. ${ }^{9}$

A sudden reversal in the fraction-of-dehydration trend at $\mathrm{T}_{\text {gas }}=390{ }^{\circ} \mathrm{C}$ in Figure $6-3$ is mostly likely due to the faulty data as evidenced by a poor carbon balance of $-24 \%$. A red dotted line is drawn beyond the data range to qualitatively mimic an S-shaped profile by assuming $100 \%$ decomposition at $600{ }^{\circ} \mathrm{C}$ based on the results of an earlier study; ${ }^{14}$ the measured fraction of formic acid decomposition in an unetched silica tube was already over $95 \%$ at $550{ }^{\circ} \mathrm{C}$.

\subsubsection{Adjustment of Vapor Space Combustion Model}

Concurrently with the development of the formic acid decomposition model shown in Figure 6-3, it was necessary to adjust the existing global oxidation kinetic parameters of $\mathrm{H}_{2}$ in order to match measured data during the non-bubbled sugar feed runs. As shown in Figure 6-4, the adjustments made were mostly to speed up the oxidation of $\mathrm{H}_{2}$ at gas temperatures below $\sim 300{ }^{\circ} \mathrm{C}$ and further allow the oxidation to proceed down to $163{ }^{\circ} \mathrm{C}$. By contrast, the existing model was set up to terminate the oxidation of both $\mathrm{CO}$ and $\mathrm{H}_{2}$ at $200{ }^{\circ} \mathrm{C}$. No adjustments were made to the existing oxidation kinetics of $\mathrm{CO}$.

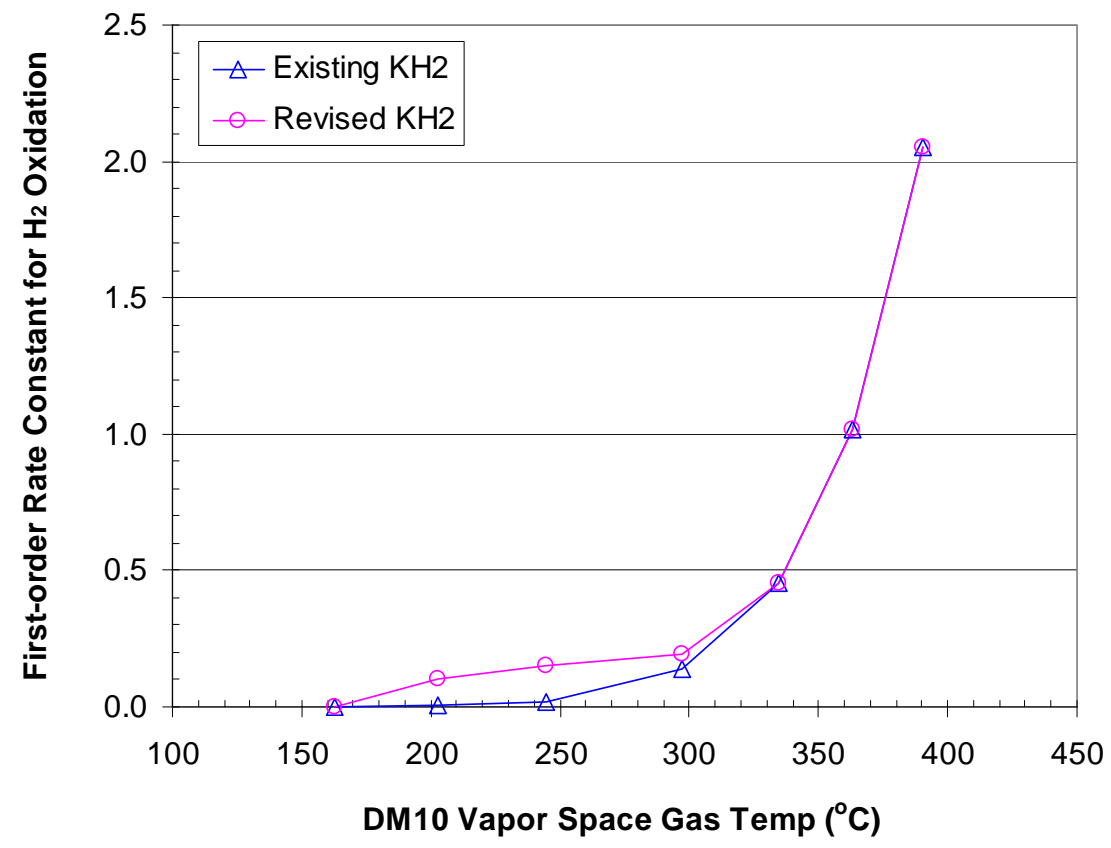

Figure 6-4. Existing vs. Revised Global First-Order Rate Constants for Oxidation of $\mathbf{H}_{2}$ from Sugar Flowsheet Feed. 


\subsection{Validation of Cold Cap Model}

The compositions of the calcine gases and glass predicted by the existing cold cap model with the input vector given in Table 4-3 are compared in Table 6-2 against the measured off-gas and glass redox data during the non-bubbled baseline feed run at $296{ }^{\circ} \mathrm{C}$ measured vapor space temperature or $\mathrm{T}_{\text {gas }}=190{ }^{\circ} \mathrm{C}$. Since the estimated gas temperature was higher than the baseline temperature of $163{ }^{\circ} \mathrm{C}$ for the formic acid decomposition and revised $\mathrm{H}_{2}$ oxidation models, the "measured" values of $\mathrm{CO}$ and $\mathrm{H}_{2}$ in Table 6-2 were actually back calculated from the off-gas data taken at the Transition Line exit after applying both models simultaneously.

It is clearly seen that the model under predicted the concentrations of $\mathrm{H}_{2}$ and $\mathrm{CO}$ by an order of magnitude, while it over predicted the glass redox ratio. It means that not enough $\mathrm{O}_{2}$ was retained in glass; instead, the excess $\mathrm{O}_{2}$ was used to oxidize $\mathrm{H}_{2}$ and $\mathrm{CO}$ in the cold cap, thus rendering the resulting calcine gases less flammable. Both the cold cap and vapor space combustion models were validated against the data taken from the $1 / 2$ scale SGM down to $1 / 80^{\text {th }}$ scale $774-\mathrm{A}$ minimelters. However, it is not certain why the discrepancy became so large for the DM10, which is $1 / 125^{\text {th }}$ scale of the DWPF melter based on melt surface area. Smaller discrepancies seen between the measured and predicted molar ratios of $\mathrm{CO} / \mathrm{CO}_{2}$ and $\mathrm{H}_{2} /\left(\mathrm{CO}+\mathrm{CO}_{2}\right)$ were due to the inherent carbon imbalance caused mostly by $\mathrm{CO}_{2}$; the measured $\mathrm{CO}_{2}$ values were always larger than those calculated for all six DM10 runs.

Table 6-2. Baseline Feed Data vs. Cold Cap Model Predictions (per 1.28 kg/hr Feed Rate).

\begin{tabular}{|c|c|c|c|}
\hline DM10 Baseline Feed & $\begin{array}{c}\text { Data by } \\
\text { VSL }\end{array}$ & $\begin{array}{c}\text { Data by } \\
\text { SRNL }\end{array}$ & $\begin{array}{c}\text { Cold Cap } \\
\text { Model }\end{array}$ \\
\hline \multicolumn{4}{|l|}{ Calcine Gases: } \\
\hline \begin{tabular}{l|l|} 
& $\mathrm{H}_{2}(\mathrm{~kg} / \mathrm{hr})$ \\
\cline { 2 - 2 }
\end{tabular} & 0.00047 & - & 0.00004 \\
\hline $\mathrm{CO}(\mathrm{kg} / \mathrm{hr})$ & 0.00077 & - & 0.00010 \\
\hline molar $\mathrm{CO} / \mathrm{CO}_{2}$ & 0.02080 & - & 0.00406 \\
\hline molar $\mathrm{H}_{2} /\left(\mathrm{CO}+\mathrm{CO}_{2}\right)$ & 0.09001 & - & 0.01967 \\
\hline \multicolumn{4}{|l|}{ Glass: } \\
\hline $\mathrm{Fe}^{2+} / \mathrm{Fe}^{\text {total }}$ (mole/mole) & 0 & 0.04 & 0.112 \\
\hline
\end{tabular}

When the cold cap model results shown in Table 6-2 were forced to match the DM10 data by converting $\mathrm{CO}_{2}$ and $\mathrm{H}_{2} \mathrm{O}$ into $\mathrm{CO}$ and $\mathrm{H}_{2}$, respectively, it was found that the excess $\mathrm{O}_{2}$ that was created in doing so was just enough to lower the glass redox ratio from 0.112 to 0.038 , the latter of which agrees well with the SRNL data. This confirms the internal consistency of the cold cap model. However, the internal consistency of the model could not be confirmed for the bubbled baseline feed run at $334{ }^{\circ} \mathrm{C}$ measured vapor space temperature or $\mathrm{T}_{\text {gas }}=210{ }^{\circ} \mathrm{C}$ due to lack of relevant glass redox data; glass redox were all measured in closed crucibles in the absence of any forced convection in the sample.

Nevertheless, the measured concentrations of $\mathrm{H}_{2}$ and $\mathrm{CO}$ during the bubbled run were somewhat higher than their counterparts measured during the non-bubbled run. Thus, ignoring the impact of bubbling on glass redox, the degrees of $\mathrm{H}_{2}$ and $\mathrm{CO}$ adjustments necessary to match the off-gas data taken during the bubbled run were 1.2 and 2.6X greater than those made for the non-bubbled run, respectively. However, it cannot be concluded that the increase in $\mathrm{H}_{2}$ and $\mathrm{CO}$ concentrations during bubbled runs was due to the bubbling action alone, since the feed rate during bubbled runs was higher by more than a factor of two, i.e., $1.4 \mathrm{vs} 3.1 \mathrm{~kg} / \mathrm{hr}$, while the total air purge was held relatively constant at comparable vapor space temperatures. 


\subsection{Further Adjustment of Cold Cap Model}

The existing cold cap model was run next with the glycolic flowsheet feed input vectors given in Table 4-4. As shown in Table 6-3, the predicted concentrations of $\mathrm{CO}$ and $\mathrm{H}_{2}$ in the calcine gases were both zero, while the data taken at $323{ }^{\circ} \mathrm{C}$ measured vapor space temperature or $\mathrm{T}_{\text {gas }}=215^{\circ} \mathrm{C}$ were non-zero although they were lower than their counterparts of the baseline feed. It means that as with the baseline feed the cold cap model predicted that more $\mathrm{O}_{2}$ would be available to oxidize the flammable gases than glass; in this case, the model allowed enough $\mathrm{O}_{2}$ to completely oxidize $\mathrm{CO}$ and $\mathrm{H}_{2}$. The lower flammability potential of the glycolic flowsheet feed than that of the baseline feed can be attributed to its low feed redox potential of -2.93 compared to -0.07 for the baseline feed. The redox potential of a feed is defined here as $F+G-3 N$, where $F, G$, and $N$ are the molar concentrations of formate, glycolate, and nitrate, respectively. Therefore, as the redox potential becomes lower or more negative, the feed becomes more oxidizing, thus resulting in greater excess $\mathrm{O}_{2}$. The large negative redox potential of the glycolic flowsheet feed was due to its high nitrate compared to the baseline feed, which was also the case for the sugar flowsheet feed.

Table 6-3. Glycolic Feed Data vs. Cold Cap Model Predictions (per 1.28 kg/hr Feed Rate).

\begin{tabular}{|c|c|c|c|}
\hline Glycolic Feed & $\begin{array}{c}\text { Data by } \\
\text { VSL }\end{array}$ & $\begin{array}{l}\text { Data by } \\
\text { SRNL }\end{array}$ & $\begin{array}{c}\text { Cold Cap } \\
\text { Model }\end{array}$ \\
\hline \multicolumn{4}{|l|}{ Calcine Gases: } \\
\hline \begin{tabular}{l|l|} 
& $\mathrm{H}_{2}(\mathrm{~kg} / \mathrm{hr})$ \\
\end{tabular} & 0.00014 & - & 0.00000 \\
\hline $\mathrm{CO}(\mathrm{kg} / \mathrm{hr})$ & 0.00050 & - & 0.00000 \\
\hline molar $\mathrm{CO} / \mathrm{CO}_{2}$ & 0.01025 & - & 0.00000 \\
\hline molar $\mathrm{H}_{2} /\left(\mathrm{CO}+\mathrm{CO}_{2}\right)$ & 0.01913 & - & 0.00000 \\
\hline \multicolumn{4}{|l|}{ Glass: } \\
\hline $\mathrm{Fe}^{2+} / \mathrm{Fe}^{\mathrm{total}}$ (mole/mole) & 0.00 & 0.17 & 0.120 \\
\hline
\end{tabular}

It is noted that since the estimated gas temperature of $215^{\circ} \mathrm{C}$ was higher than $163{ }^{\circ} \mathrm{C}$, which was selected as the baseline temperature for the decomposition/combustion analysis, the "measured" concentrations of $\mathrm{CO}$ and $\mathrm{H}_{2}$ in Table 6-3 also had to be back calculated from the data taken at the Transition Line exit by simultaneously applying both the formic acid decomposition model shown in Figure 6-3 and the revised combustion kinetics of $\mathrm{H}_{2}$ shown in Figure 6-4. However, such manipulation was more involved for the glycolic flowsheet feed than for the baseline feed, since over $50 \%$ of the glycolate analyzed by IC was determined to be in un-dissociated form, as shown in Table 4-2, which means that not only formic acid but glycolic acid will boil off from the glycolic flowsheet feed and may decompose in the vapor space. This necessitates the need for a model of glycolic acid decomposition, and the basis for doing so was the non-bubbled glycolic flowsheet feed run data taken at $323{ }^{\circ} \mathrm{C}$; the calculated $\Delta \mathrm{T}$ was within the expected range but the carbon balance was not good $(-20 \%)$.

\subsubsection{Development of Glycolic Acid Decomposition Model}

There are two ways to adjust the cold cap model predictions so that they would match the data. The first is to follow the same path used in the baseline feed case by converting $\mathrm{H}_{2} \mathrm{O}$ and $\mathrm{CO}_{2}$ into $\mathrm{H}_{2}$ and $\mathrm{CO}$, respectively, and using the excess $\mathrm{O}_{2}$ that is created to lower the glass redox ratio. The other way is to create $\mathrm{CO}$ and $\mathrm{H}_{2}$ from the gas-phase decomposition of formic and glycolic acids. According to Figure 6-3, however, formic acid will not decompose via the decarboxylation route until $\mathrm{T}_{\text {gas }}>300{ }^{\circ} \mathrm{C}$, which means that $\mathrm{H}_{2}$ must be created by the decomposition of glycolic acid. The following global 2-step thermal decomposition of glycolic acid vapor was used: ${ }^{17,18}$ 


$$
\begin{aligned}
& \mathrm{HOCH}_{2} \mathrm{COOH} \rightarrow \mathrm{HCHO}+\mathrm{CO}+\mathrm{H}_{2} \mathrm{O} \\
& \mathrm{HCHO} \rightarrow \mathrm{CO}+\mathrm{H}_{2}
\end{aligned}
$$

The formation of $\mathrm{H}_{2} \mathrm{O}$ and $\mathrm{CO}$ in Eq. (18) is in principle identical to the dehydration path used for formic acid decomposition in Eq. (11), since both formic and glycolic acids belong to the same carboxylic acid group. The percent conversion of Reaction (18) was found by matching the measured $\mathrm{CO}$ and $\mathrm{H}_{2}$ data at the Transition Line exit, after making the following assumption:

- Glycolic acid volatilizes at $112{ }^{\circ} \mathrm{C}$ but remains un-decomposed until $\mathrm{T}_{\text {gas }}=215^{\circ} \mathrm{C}$.

Therefore, the percent conversion of Reaction (18) was effectively set to zero at $\mathrm{T}_{\text {gas }}=215^{\circ} \mathrm{C}$ and the cold cap model output shown in Table 6-3 was adjusted to match the measured $\mathrm{CO}$ and $\mathrm{H}_{2}$ data at the Transition Line exit. So, unless there was a shortage in $\mathrm{CO}$ at higher temperatures with the same adjusted cold cap model output, the percent conversion of Reaction (18) remained zero. On the other hand, the percent conversion of formaldehyde decomposition via Reaction (19) was estimated from Figure 6-5 using both catalyzed and un-catalyzed curves for comparison purposes, although no $\mathrm{Na}_{2} \mathrm{CO}_{3}$ catalyst was present in the DM10 vapor space. Compared to formic acid, formaldehyde is shown to be thermally stable since it does not decompose appreciably until $\mathrm{T}_{\text {gas }}=$ $\sim 600 \mathrm{~K}$ or $327{ }^{\circ} \mathrm{C}$ even in the presence of catalysts. This substantiates the overall decomposition scheme shown in Eqs. (18) and (19); formaldehyde does not form until glycolic acid begins to decompose at $215{ }^{\circ} \mathrm{C}$ and, once formed, it will begin to decompose at $\mathrm{T}_{\text {gas }}>\sim 300{ }^{\circ} \mathrm{C}$.

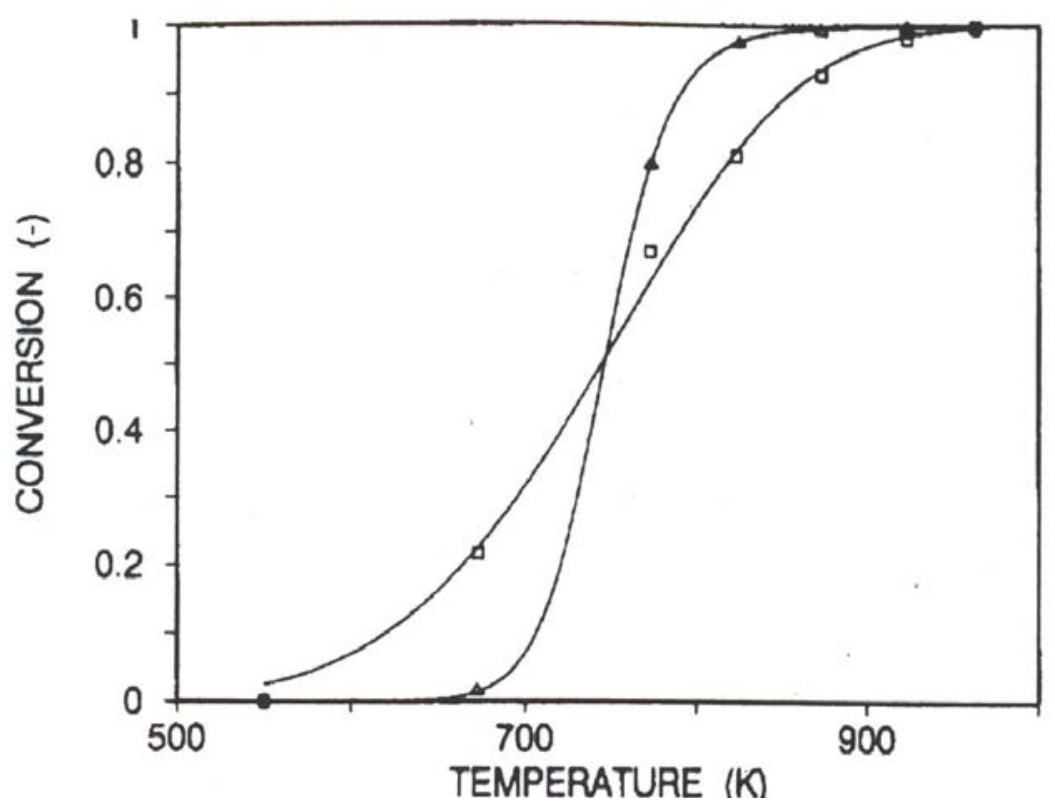

Figure 6-5. Effects of $\mathrm{Na}_{2} \mathrm{CO}_{3}$ Catalyst on $\mathrm{HCHO}$ Decomposition-catalyzed (open symbol); un-catalyzed (closed symbol)-taken from Ref. [18]. 


\subsubsection{Adjustment of Cold Cap Model for Glycolic Flowsheet Feed}

The cold cap model output shown in Table 6-3 was adjusted by converting $\mathrm{H}_{2} \mathrm{O}$ and $\mathrm{CO}_{2}$ into $\mathrm{H}_{2}$ and $\mathrm{CO}$, respectively, and using the excess $\mathrm{O}_{2}$ thus created to lower the glass redox ratio, as done for the baseline feed. The excess $\mathrm{O}_{2}$ thus generated by the adjustments was $0.0014 \mathrm{~kg} / \mathrm{hr}$ at 1.28 $\mathrm{kg} / \mathrm{hr}$ feed rate, which is equivalent to $0.02 \%$ of the total air inleakage for that run. Calculations further showed that this excess $\mathrm{O}_{2}$ was 2.5 times the amount required to reduce the calculated glass redox ratio from 0.12 to 0 , as measured by VSL, which means that forcing the glass redox ratio to match the data alone will not generate enough $\mathrm{O}_{2}$ to oxidize $\mathrm{CO}$ and $\mathrm{H}_{2}$ to their respective measured levels. This is exactly the opposite of what was seen in the sugar flowsheet feed runs. We may contribute this "broken" internal consistency of the model again to incompatible oxidant and reductant data used to build the SRAT product. It is, however, noted that the carbon balance of this glycolic flowsheet feed run was poor, $-20 \%$ vs. $-0.7 \%$ for the non-bubbled sugar feed data, which puts the credibility of the off-gas data in Table 6-3 into question.

The adjusted cold cap model output was then used to determine the conversion of glycolic acid decomposition at higher temperatures. It turns out that since the predicted concentration of $\mathrm{CO}$ was already somewhat higher than measured data, there was no need to turn on Reaction (18) only to produce additional excess CO. Due to the aforementioned errors in the TT-07 readings at 471 and $423{ }^{\circ} \mathrm{C}$ measured vapor space temperatures, the calculated $\mathrm{H}_{2}$ concentration was forced to match measured data by varying $\mathrm{T}_{\text {gas }}$ without turning on Reaction (19), and the resulting $\Delta \mathrm{T}$ values were all within the expected range. Besides, once Reaction (18) is turned off, Reaction (19) becomes irrelevant.

\subsection{Summary of Model Development, Adjustment and Validation}

The efforts to develop, adjust and validate the models described so far proceeded as follows:

1. The bubbled and non-bubbled sugar flowsheet feed run data taken at the measured vapor space temperatures of 241 and $258{ }^{\circ} \mathrm{C}$, respectively, were used to adjust the existing cold cap model for the sugar flowsheet feed run under bubbled and non-bubbled conditions.

2. The entire non-bubbled sugar flowsheet feed run data along with the adjusted cold cap model for the non-bubbled sugar flowsheet feed run were used to develop a formic acid decomposition model and revise the global $1^{\text {st }}$-order kinetics model for $\mathrm{H}_{2}$ oxidation.

3. The existing cold cap model was run with the baseline flowsheet feed along with the formic acid decomposition and revised $\mathrm{H}_{2}$ oxidation models for validation.

4. The bubbled and non-bubbled glycolic flowsheet feed run data taken at the measured vapor space temperatures of 323 and $257{ }^{\circ} \mathrm{C}$, respectively, along with the formic acid decomposition and revised $\mathrm{H}_{2}$ oxidation models were used to adjust the existing cold cap model for the glycolic acid flowsheet feed run under bubbled and non-bubbled conditions.

5. The entire non-bubbled glycolic feed run data along with the adjusted cold cap model for the non-bubbled glycolic flowsheet feed run, formic acid decomposition and revised $\mathrm{H}_{2}$ oxidation models were used to develop a glycolic acid decomposition model.

Error! Reference source not found.Table 6-4 summarizes the absolute scales of $\mathrm{H}_{2}$ and $\mathrm{CO}$ adjustments made to match the off-gas data taken at the lowest vapor space temperature in each of the six DM10 runs. As explained earlier, the positive adjustments made for the baseline and glycolic flowsheet feeds indicate that the existing cold cap model under predicted the data, and 
both $\mathrm{CO}$ and $\mathrm{H}_{2}$ were adjusted up by converting $\mathrm{CO}_{2}$ and $\mathrm{H}_{2} \mathrm{O}$ into $\mathrm{CO}$ and $\mathrm{H}_{2}$, respectively, and the $\mathrm{O}_{2}$ thus generated was used to lower the glass redox. For the sugar flowsheet feed, the adjustments made were negative, and the predicted $\mathrm{CO}$ and $\mathrm{H}_{2}$ both had to be adjusted down. For the baseline feed, the adjusted $\mathrm{CO}, \mathrm{H}_{2}$ and glass redox ratio all matched their respective data simultaneously, which was an indication that the existing model was internally consistent with the data. However, this was not the case for the glycolic and sugar flowsheet feeds.

Table 6-4. Summary of Cold Cap Model Adjustments (per 1.28 kg/hr Feed Rate).

\begin{tabular}{||l|c|c|c|c|c|c||}
\hline \multirow{2}{*}{ Calcine Gases: } & \multicolumn{2}{|c|}{ Baseline Feed } & \multicolumn{2}{c|}{ Glycolic Feed } & \multicolumn{2}{c||}{ Sugar Feed } \\
\cline { 2 - 7 } & Non-Bubbled & Bubbled & Non-Bubbled & Bubbled & Non-Bubbled & Bubbled \\
\hline $\mathrm{H}_{2}(\mathrm{~kg} / \mathrm{hr})$ & 0.00043 & 0.00051 & 0.00014 & 0.00017 & -0.00036 & -0.00042 \\
\hline $\mathrm{CO}(\mathrm{kg} / \mathrm{hr})$ & 0.00066 & 0.00170 & 0.00050 & 0.00130 & -0.00148 & -0.00086 \\
\hline \hline
\end{tabular}

Since the entire non-bubbled sugar and glycolic flowsheet feed run data were used in Steps 2 and 5 above, respectively, the adjusted cold cap, formic/glycolic acid decomposition, and revised $\mathrm{H}_{2}$ oxidation models could be validated using data from the remaining four DM10 runs, including three bubbled and one non-bubbled baseline feed runs. And the validation of these models was done after the DM10 air inleakage and film cooler air flows were re-baselined to the DWPF melter. The results of such validation and additional analyses relevant to DWPF are presented in the next section.

\subsection{Application to DWPF}

In DWPF, a constant air purge is made to the melter through several different sources, including the primary and backup film coolers, to ensure adequate air supply for combustion and cooling. The current DWPF safety basis minimum air purge for mitigating the potential for melter off-gas flammability is $900 \mathrm{lb} / \mathrm{hr}$ for feed rates up to $1.5 \mathrm{GPM}$. Since the DM10 data were collected while intentionally varying the opening of the dilution air damper in order to achieve different thermal conditions in the vapor space, they could not reflect the true measure of off-gas flammability potential had the air purge been maintained constant regardless of the feed rate or temperature, as in the DWPF melter. As a result, the total air purge to the DM10 was re-baselined as follows:

- Both the film cooler air purge of $15 \mathrm{scfm}$ and the estimated air inleakage to the DM10 were subtracted from the measured off-gas flow at the Transition Line exit.

- The equivalent DM10 feed rate (to 1.5 GPM DWPF feed rate) was set at 0.0044 GPM or $1.4 \mathrm{~kg} / \mathrm{hr}$, which was the feed rate for the non-bubbled baseline feed run at $296^{\circ} \mathrm{C}$.

- The DWPF-to-DM10 maximum feed rate ratio was calculated as:

$$
\text { Ratio }=(1.5)(45) /(0.0044)(T S)
$$

where TS is the $\mathrm{wt} \%$ total solids of a particular feed.

- The equivalent DM10 minimum air purge (to $900 \mathrm{lb} / \mathrm{hr}$ DWPF minimum) was calculated as:

$$
\text { DM10 Air Purge }=870^{*} / \text { Ratio }
$$


* Since the air purge to one of the two TV cameras is currently valved out, $30 \mathrm{lb} / \mathrm{hr}$ is purged back out to the cell, leaving $870 \mathrm{lb} / \mathrm{hr}$ for the melter.

- Finally, the equivalent DM10 minimum air purge was added to the "reduced" off-gas flow at the Transition Line exit.

The DM10 bubbling rates were 1.4 to $2.4 \mathrm{X}$ higher than the DWPF bubbling rates per unit melt surface area basis with the highest bubbling rates occurring during the glycolic flowsheet feed runs. Data seem to show increased off-gas flammability when the DM10 was bubbled; however, increased off-gas flammability cannot be attributed conclusively to bubbling, since the feed rate was doubled at the same time while the air purges were held relatively constant at comparable vapor space temperatures. Thus, the difference in bubbling flux between the DM10 and DWPF melter was not factored in during subsequent analyses.

\subsection{Results of Model Validation}

The adjusted cold cap models along with the formic/glycolic acid decomposition and revised $\mathrm{H}_{2}$ oxidation models were validated simultaneously using data from the three bubbled runs. The validation against the non-bubbled baseline feed run was not feasible due to questionable data. The predicted off-gas flammability potential in terms of percent lower flammability limit (\% LFL) for the bubbled baseline feed run is compared in Figure 7-1 to measured data. Even though the cold cap model was adjusted to match the data taken at $\mathrm{T}_{\text {gas }}=210^{\circ} \mathrm{C}$, it is still shown to under predict the data taken at higher temperatures; part of the reason is the higher rate of $\mathrm{H}_{2}$ oxidation under the revised kinetic model shown in Figure 6-4. However, the expected trend of decreasing off-gas flammability with increasing temperature is more clearly shown by the model. The flat profile of measured data at $\mathrm{T}_{\text {gas }}>237{ }^{\circ} \mathrm{C}$ is questionable, since the data taken at $\mathrm{T}_{\text {gas }}=306{ }^{\circ} \mathrm{C}$ has a poor carbon balance. According to Table 5-1, only the data taken at $\mathrm{T}_{\text {gas }}=237^{\circ} \mathrm{C}$ passed the criteria for being good-quality data; $\Delta \mathrm{T}$ within the expected range shown in Figure 5-2 and the carbon balance $\leq \pm 15 \%$. A better agreement may have been obtained had the cold cap model been adjusted using this data point.

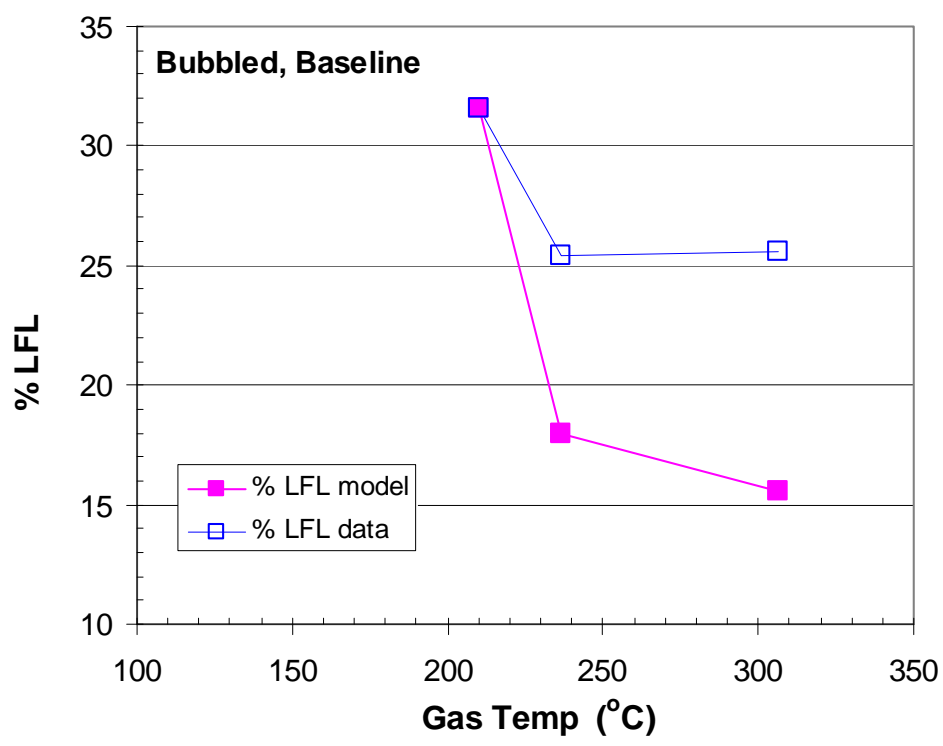

Figure 7-1. Predicted vs. Measured Off-Gas Flammability for Bubbled Baseline Feed Run. 
The predicted off-gas flammability potential for the bubbled glycolic feed run is compared in Figure 7-2 to measured data. A good agreement between the model predictions and the data is partly due to the fact that the actual TT-07 data collected were adjusted up by $17{ }^{\circ} \mathrm{C}$, as explained earlier. In addition, both the model and data clearly show the expected trend of decreasing off-gas flammability with increasing temperature.

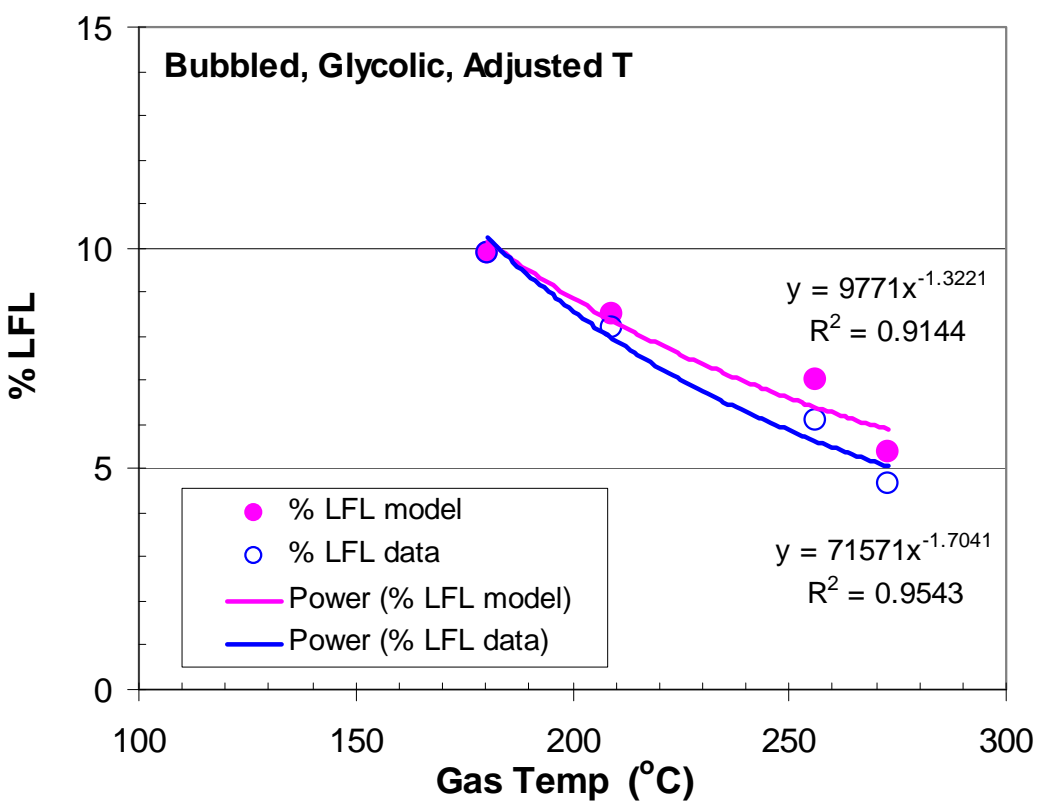

Figure 7-2. Predicted vs. Measured Off-Gas Flammability for Bubbled Glycolic Feed Run.

The predicted off-gas flammability potential for the bubbled sugar feed run is compared in Figure 7-3 to measured data. The agreement between the model predictions and the data is reasonably good considering the fact that they vary by less $3 \%$ of the LFL over the temperature range greater than $250{ }^{\circ} \mathrm{C}$. Unlike the baseline and glycolic flowsheet feeds, however, the model and data both show a more or less flat off-gas flammability profile with temperature. It is not certain why the sugar flowsheet feed behaves this way. One possible explanation would be that the decomposition of sucrose in the cold cap does not produce any significant amounts of flammable gases that can be burned later in the vapor space according to the oxidation kinetics of the flammable gases.

\subsection{Impact of Feed Reductant on Off-Gas Flammability}

It is shown in Figure 7-4 that under non-bubbled conditions the baseline feed has $\sim 3 \mathrm{X}$ higher flammability potential than either the glycolic or sugar flowsheet feed, while the latter two have similar potentials. Despite lack of the baseline data above $\mathrm{T}_{\text {gas }}>200{ }^{\circ} \mathrm{C}$, it may be postulated that the flammability potential gap between the baseline and either the glycolic or sugar flowsheet feeds will shrink considerably at gas temperatures higher than $\sim 350{ }^{\circ} \mathrm{C}$ or measured vapor space temperatures higher than $\sim 500{ }^{\circ} \mathrm{C}$ due to accelerated kinetics of both $\mathrm{H}_{2}$ and $\mathrm{CO}$ oxidation. The DM10 was run purposely at low measured vapor space temperatures $\leq 500{ }^{\circ} \mathrm{C}$ in order to generate necessary data for the study of the cold cap chemistry and its contribution to off-gas flammability. It is noted, however, that the DWPF melter is nominally run at vapor space temperatures considerably higher than $500{ }^{\circ} \mathrm{C}$. 


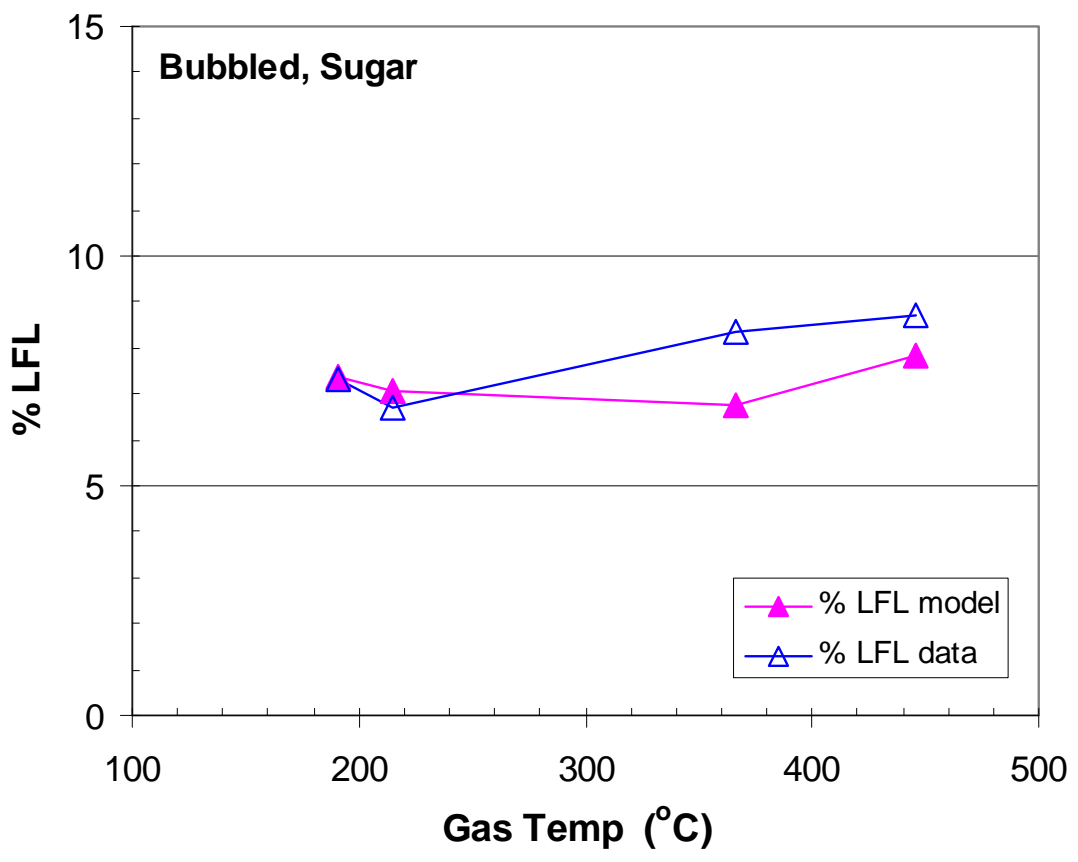

Figure 7-3. Predicted vs. Measured Off-Gas Flammability for Bubbled Sugar Feed Run.

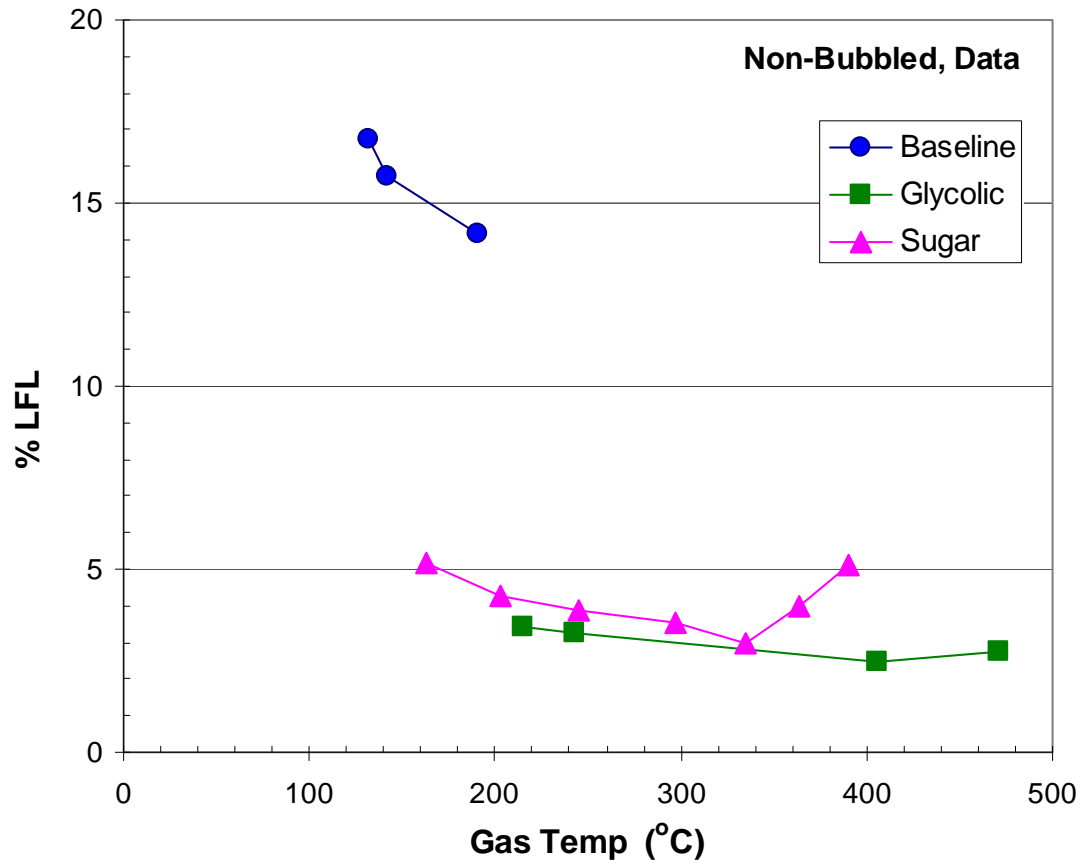

Figure 7-4. Impact of Reductant on Off-Gas Flammability for Non-Bubbled Op. 
Figure 7-5 shows that under bubbled conditions the off-gas flammability potential of the baseline feed is still considerably higher than that of either the glycolic or sugar flowsheet feed especially at low gas temperatures below $\sim 250{ }^{\circ} \mathrm{C}$ due to slow kinetics of $\mathrm{H}_{2}$ and $\mathrm{CO}$ oxidation. At higher temperatures, however, the gap is narrower than that of the non-bubbled operation. It is noted that only the model predicted bubbled run results are shown in Figure 7-5 since several questionable data points leave too few data to show as meaningful trends.

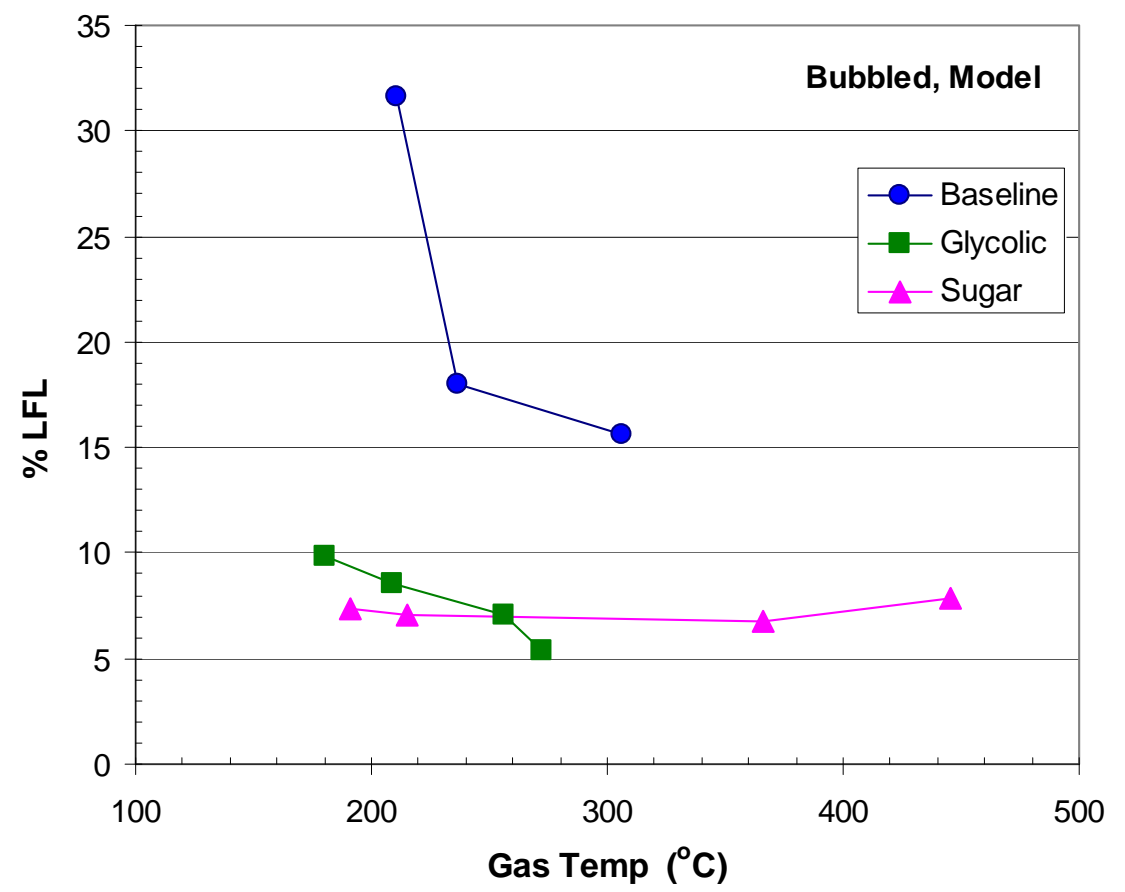

Figure 7-5. Impact of Reductant on Off-Gas Flammability for Bubbled Op.

\subsection{Impact of Bubbling on Off-Gas Flammability}

Figure 7-6 shows how bubbling would impact the off-gas flammability of the baseline feed under the DWPF air purge scenario. Since the temperature ranges of the bubbled and non-bubbled data do not overlap, no direct comparison can be made. However, a little extrapolation of data clearly shows that bubbling produced more flammable gases particularly at low temperatures than under non-bubbled conditions. And this was expected since under bubbling the feed rate was more than doubled, while the air purge rate was held relatively constant at a given vapor space temperature, thus resulting in a higher off-gas flammability potential under bubbled conditions. It appears from Figure 7-6 that the off-gas flammability gap between bubbled and non-bubbled operations will shrink at higher temperatures due to accelerated kinetics of $\mathrm{H}_{2}$ and $\mathrm{CO}$ oxidation. It is noted that the non-bubbled profile shown is based on actual data but the bubbled profile is based on the model results due to lack of quality data.

For the glycolic flowsheet feed, the off-gas flammability gap between bubbled and non-bubbled operations is shown in Figure 7-7 to be disappearing fast at $\sim 300{ }^{\circ} \mathrm{C}$ and may even become negative at higher temperatures. On the other hand, for the sugar flowsheet feed, the gap is shown in Figure 7-8 to remain relatively constant for the entire temperature range considered. And this constant gap may very well represent the difference in feed rate between bubbled and nonbubbled operations. 


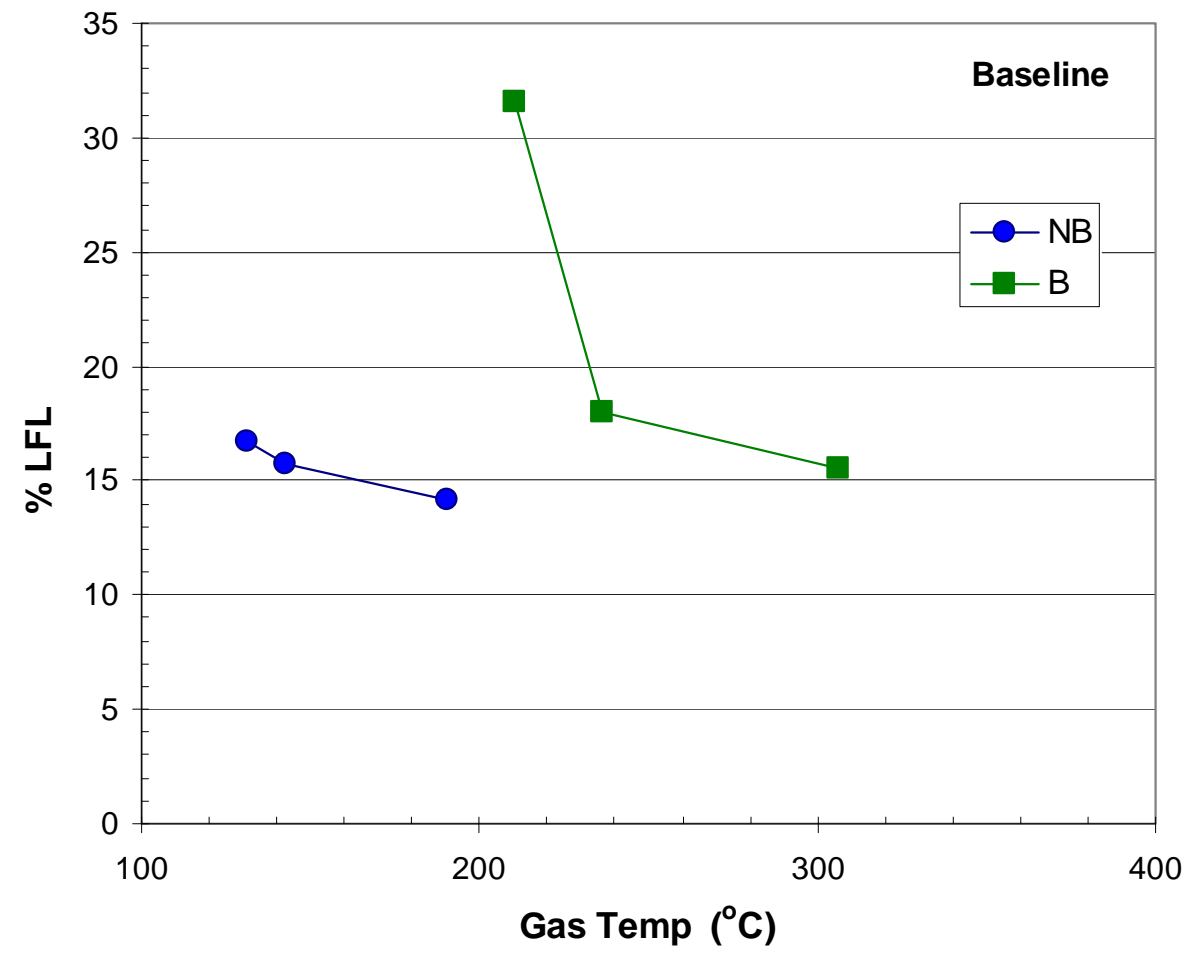

Figure 7-6. Impact of Bubbling on Off-Gas Flammability of Baseline Feed.

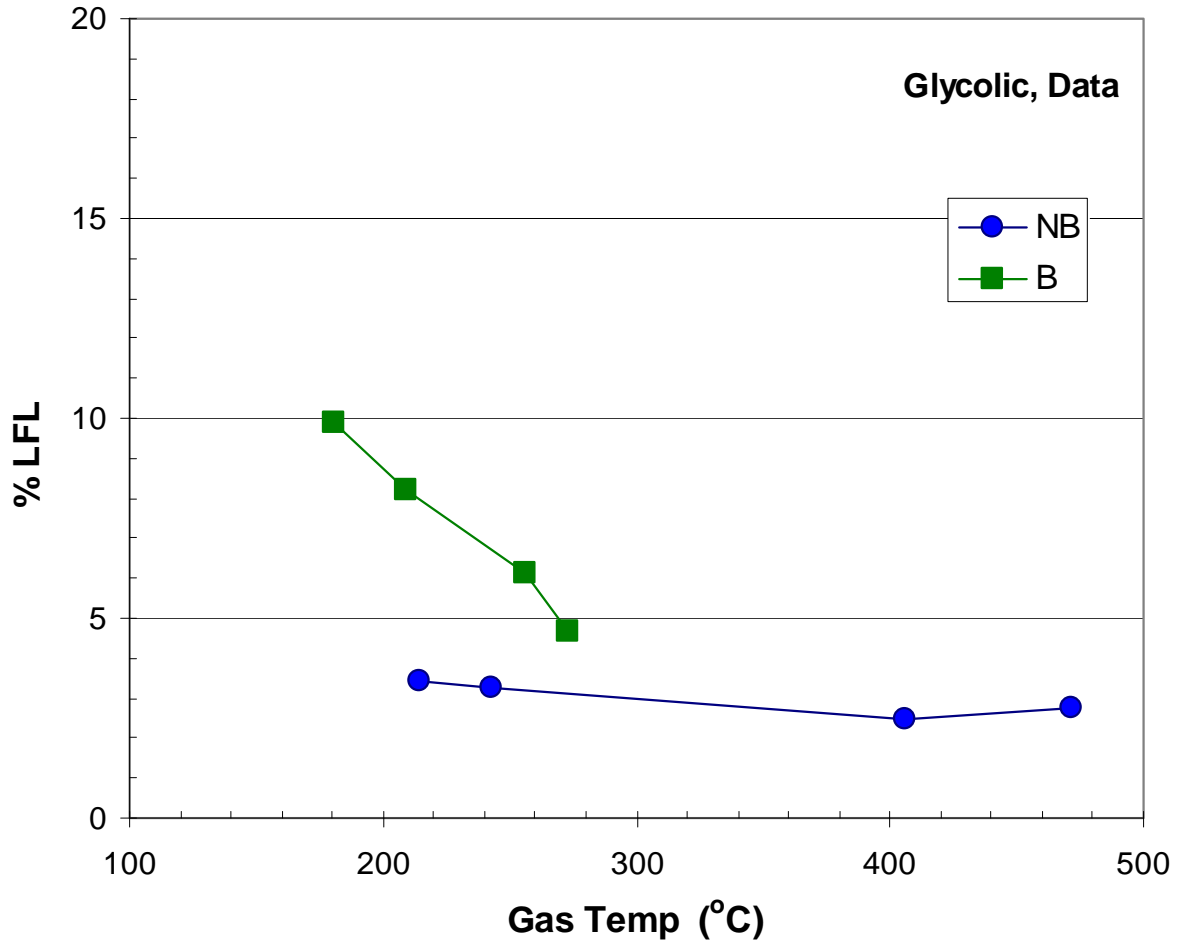

Figure 7-7. Impact of Bubbling on Off-Gas Flammability of Glycolic Flowsheet Feed. 
SRNL-STI-2011-00321

Revision 0

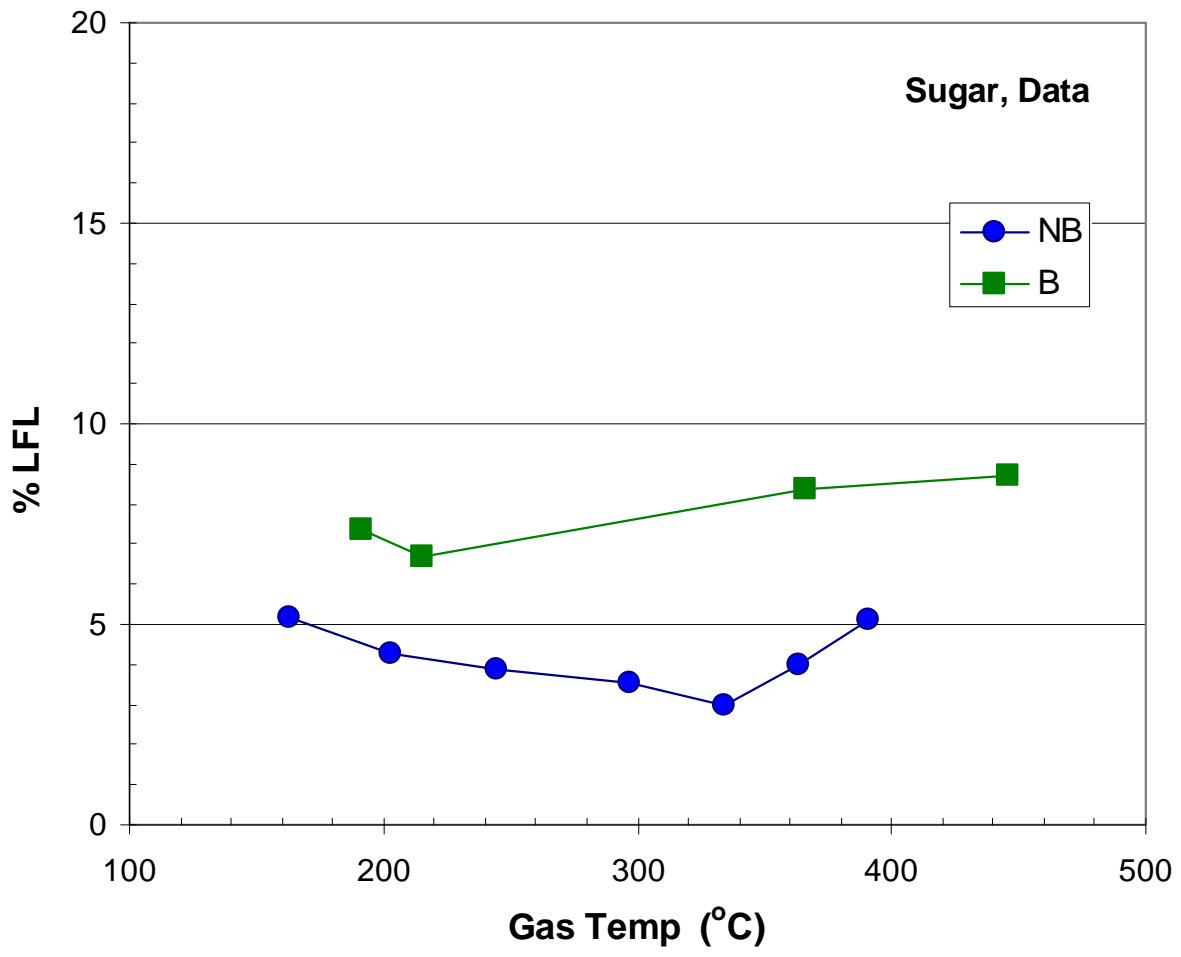

Figure 7-8. Impact of Bubbling on Off-Gas Flammability of Sugar Flowsheet Feed. 


\subsection{Conclusions}

The DM10 data were analyzed, modeled and extended all in an effort to quantify the impact of different reductant flowsheet feeds on the DWPF melter off-gas flammability. Based on the results of such activities presented in this report, the following conclusions can be drawn:

1. The baseline formic acid flowsheet feed has $\sim 3 \mathrm{X}$ higher melter off-gas flammability potential than either the glycolic acid or sugar-based flowsheet feed at measured vapor space temperatures $\leq 500{ }^{\circ} \mathrm{C}$.

2. The melter off-gas flammability potentials of the glycolic and sugar-based flowsheet feeds are similar at measured vapor space temperatures $\leq 500{ }^{\circ} \mathrm{C}$.

3. The $3 \mathrm{X}$ difference in melter off-gas flammability potential between the baseline and either alternate reductant feeds is expected to decrease significantly at typical vapor space operating temperatures $>500{ }^{\circ} \mathrm{C}$ for both bubbled and non-bubbled operations due to increased kinetics of $\mathrm{H}_{2}$ and $\mathrm{CO}$ oxidation.

4. Bubbling increases the melter off-gas flammability potential likely due to increased feed rate at a relatively constant air purge rate.

5. It appears that over $50 \%$ of the glycolate detected by IC in the glycolic flowsheet feed remained un-dissociated and exited the melter as such, thus having no significant impact on either the glass redox or melter off-gas flammability potential. The condensed glycolic acid will then have to be neutralized and recycled back to the Tank Farms.

6. The existing DWPF cold cap model under predicted the $\mathrm{H}_{2}$ and $\mathrm{CO}$ data taken during the baseline flowsheet feed runs. However, the under prediction was most likely caused by the inadequacy of data, which in turn was caused by the inherent difficulty of maintaining steady state operation under the non-prototypic design and operating conditions of the DM10 coupled with the fact that insufficient run time was allocated to each steady state due to a limited supply of feed.

In order to confirm and further substantiate the conclusions of this work, it is recommended that:

1. A proof-of-principle testing be performed by employing a larger, continuously-fed and poured melter and allowing sufficient time for the system to reach steady state before data collection.

A larger size will help; (1) maintain a more prototypic cold cap under both bubbled and non-bubbled conditions and (2) quantify off-gas surging potentials of the alternate reductant feeds relative to that of the baseline formic acid flowsheet feed. The continuous feeding and pouring capability will help maintain steady state better and longer.

2. Using the proof-of-principle test data, validate the formic acid decomposition and revised $\mathrm{H}_{2}$ oxidation models and further revise the cold cap model for the selected alternate reductant flowsheet feed. 
SRNL-STI-2011-00321

Revision 0

\subsection{References}

1. Kot, W. K., Brandys, M., Matlack, K. S., Pegg, I. L., and Diener, G. A., "Test PlanAlternate Reductant Flowsheet Development for the Defense Waste Processing Facility," VSL-10T2020-1, Rev. 2, VSL, The Catholic University of America, Washington, DC, and EnergySolutions Federal EPC, Inc., Columbia, MD, January 7, 2011.

2. Matlack, K. S., Kot, W. K., D’Angelo, N., Pegg, I. L., Diener, G. A., and Joseph, I. "Final Report-Melter Testing of Alternate Reductant Flow-Sheets for the Defense Waste Processing Facility," VSL-11R2020-3, Rev. 0, VSL, The Catholic University of America, Washington, DC, and EnergySolutions Federal EPC, Inc., Columbia, MD, April 26, 2011.

3. Matlack, K. S., Kot, W. K., D’Angelo, N., Pegg, I. L., Diener, G. A., and Joseph, I. "Final Report-Off-Gas Data from DM10 Melter Testing of Alternate Reductant FlowSheets for the Defense Waste Processing Facility," VSL-11R2020-4, Rev. 0, VSL, The Catholic University of America, Washington, DC, and EnergySolutions Federal EPC, Inc., Columbia, MD, April 26, 2011.

4. Pickenheim, B. R., and Choi, A. S., "Task Technical and Quality Assurance Plan for Glycolic-Formic Acid Flowsheet Development, Definition and Demonstration Tasks 47A," SRNL-RP-2009-00484, Rev. 2, October 2010.

5. Choi, A. S., "DWPF Melter Off-Gas Flammability Assessment (Sludge Batch 6 and 7A)," X-CLC-S-00164, Rev. 5, Savannah River National Laboratory, Aiken, SC, March 2011.

6. Choi, A. S., Peeler, D. K., and Edwards, T. B., "Modeling Melt Rate for DWPF: a Preliminary Assessment,” Ceramic Transactions, 176, 179-190 (2006).

7. Choi, A. S., "Validation of DWPF Melter Off-Gas Combustion Model," WSRC-TR2000-00100, Westinghouse Savannah River Co., Aiken, SC, June 23, 2000.

8. Choi, A. S., "Validation of DWPF MOG Dynamics Model - Phase I," WSRC-TR-960307, Westinghouse Savannah River Co., Aiken, SC, January 7, 1997.

9. Saito, K., Shiose, T., Takahashi, O., Hidaka, Y., Aiba, F., and Tabayashi, K.," Unimolecular Decomposition of Formic Acid in the Gas Phases On the Ratio of the Competing Reaction Channels,” J. Phys. Chem. A, 109, 5352-5357 (2005).

10. Bone, W. and Gardner, J. B., "Comparative Studies of the Slow Combustion of Methane, Methyl Alcohol, Formaldehyde, and Formic Acid," Proc. Roy. Soc., Vol. A, 297-328 (1936).

11. Choi, A. S., Rabon, G. F., Smith, M. E., Goudelock, S. L., Crow, K. R., Wehner, A. M., and Baron, M. R., "Summary of Campaigns SGM-9 and SGM-10 of the DWPF Scale Glass Melter," DPST-88-626, E. I. du Pont de Nemours, Aiken, SC, December 15, 1988. 
12. Goles, R. W., and Sevigny, G. J., "Off-Gas Characteristics of Defense Waste Vitrification Using Liquid Fed Joule-Heated Ceramic Melters," PNL-4819, Pacific Northwest Laboratory, Richland, WA (1983)

13. Lambert, D. P., Pickenheim, B. R., Stone, M. E., Newell, J. D., and Best, D. R., "Glycolic-Formic Acid Flowsheet Final Report for Downselect Decision," SRNL-STI2010, 00523, Rev. 1, Savannah River National Laboratory, Aiken, SC, March 9, 2011.

14. Nelson, W. L., and Engelder, C. J., "The Thermal Decomposition of Formic Acid," J. Phys. Chem., 30 (4), 470-475 (1926).

15. Wescott, B. B., and Engelder, C. J., "The Catalytic Decomposition of Formic Acid," J. Phys. Chem., 30 (4), 476-479 (1926).

16. Blake, P. G., and Hinshelwood, C., "The Homogeneous Decomposition Reactions of Gaseous Formic Acid,” Proc. Roy. Soc. London, Ser. A, 255, 444-455 (1960).

17. Domingo, L. R., Andres, J., Moliner, V., and Safont, V. S., "Theoretical Study of the Gas Phase Decomposition of Glycolic, Lactic, and 2-Hydroxyisobutyric Acid," J. Am. Chem. Soc., 119, 6415-6422 (1997).

18. Su, S., Prairie, M., and Renken, A., "Reaction Mechanism of Methanol Dyhydrogenation on a Sodium Carbonate Catalyst,” Applied Catalysis A: General, 91, 131-142 (1992). 
SRNL-STI-2011-00321

Revision 0

Appendix A.

Steady State DM10 Data 


\section{Baseline Feed, Non-Bubbled}

From: 01/04/2011 16:30:39

To: 01/04/2011 17:30:40

\begin{tabular}{|c|c|c|c|c|c|c|c|c|c|c|c|c|c|c|}
\hline & $\begin{array}{c}\text { plenum } \\
\text { exposed* }\end{array}$ & $\begin{array}{l}\text { Feed } \\
\text { Rate }\end{array}$ & $\begin{array}{c}\text { Bubbling } \\
\text { Rate }\end{array}$ & $\begin{array}{l}\text { Heated } \\
\text { FC air }\end{array}$ & $\begin{array}{c}\text { FC } \\
\text { Outlet } \\
\end{array}$ & $\begin{array}{c}\text { Transition } \\
\text { Outlet }\end{array}$ & $\begin{array}{l}\text { Stack } \\
\text { Flow }\end{array}$ & $\begin{array}{l}\text { Stack } \\
\text { Flow }\end{array}$ & $\begin{array}{l}\text { Stack } \\
\text { Flow }\end{array}$ & $\begin{array}{l}\mathrm{H}_{2-} \\
\mathrm{GC} \\
\end{array}$ & $\begin{array}{c}\mathrm{H}_{2^{-}} \\
\text {Sensor } \\
\end{array}$ & $\mathrm{CO}$ & $\mathrm{CO}_{2}$ & $\mathrm{H}_{2} \mathrm{O}$ \\
\hline & $\left({ }^{\circ} \mathrm{C}\right)$ & (kg/hr) & (lpm) & $\left({ }^{\circ} \mathrm{C}\right)$ & $\left({ }^{\circ} \mathrm{C}\right)$ & $\left({ }^{\circ} \mathrm{C}\right)$ & dscfm & scfm & acfm & ppm & ppm & ppm & vol\% & vol\% \\
\hline average & 483.7 & 1.34 & 0.0 & 257.0 & 241.3 & 231.8 & 16.31 & 17.10 & 29.79 & 161.9 & 208.7 & 56.43 & 0.181 & 4.587 \\
\hline std dev & 3.48 & 0.25 & - & 0.92 & 1.38 & 0.45 & 0.12 & 0.11 & 0.20 & 32.1 & 38.6 & 11.85 & 0.017 & 0.365 \\
\hline $\max$ & 490.4 & 1.83 & 0.0 & 257.9 & 243.8 & 232.7 & 16.62 & 17.34 & 30.22 & 211.3 & 273.7 & 81.57 & 0.211 & 5.486 \\
\hline $\min$ & 477.9 & 0.58 & 0.0 & 255.4 & 238.6 & 230.8 & 15.96 & 16.77 & 29.22 & 110.6 & 140.8 & 33.71 & 0.148 & 3.998 \\
\hline
\end{tabular}

* Represents one reading from TT-05.

From: 01/05/2011 17:31:00

To: 01/05/2011 18:33:01

\begin{tabular}{|c|c|c|c|c|c|c|c|c|c|c|c|c|c|c|}
\hline & $\begin{array}{c}\text { plenum } \\
\text { exposed }\end{array}$ & $\begin{array}{l}\text { Feed } \\
\text { Rate }\end{array}$ & $\begin{array}{c}\text { Bubbling } \\
\text { Rate }\end{array}$ & $\begin{array}{l}\text { Heated } \\
\text { FC air }\end{array}$ & $\begin{array}{c}\text { FC } \\
\text { Outlet } \\
\end{array}$ & $\begin{array}{c}\text { Transition } \\
\text { Outlet }\end{array}$ & $\begin{array}{l}\text { Stack } \\
\text { Flow }\end{array}$ & $\begin{array}{l}\text { Stack } \\
\text { Flow }\end{array}$ & $\begin{array}{l}\text { Stack } \\
\text { Flow }\end{array}$ & $\begin{array}{l}\mathrm{H}_{2^{-}} \\
\mathrm{GC} \\
\end{array}$ & $\begin{array}{c}\mathrm{H}_{2^{-}} \\
\text {Sensor }\end{array}$ & $\mathrm{CO}$ & $\mathrm{CO}_{2}$ & $\mathrm{H}_{2} \mathrm{O}$ \\
\hline & $\left({ }^{\circ} \mathrm{C}\right)$ & $(\mathrm{kg} / \mathrm{hr})$ & $(\mathrm{lpm})$ & $\left({ }^{\circ} \mathrm{C}\right)$ & $\left({ }^{\circ} \mathrm{C}\right)$ & $\left({ }^{\circ} \mathrm{C}\right)$ & dscfm & scfm & acfm & $\mathrm{ppm}$ & $\mathrm{ppm}$ & $\mathrm{ppm}$ & $\mathrm{vol} \%$ & vol $\%$ \\
\hline average & 373.16 & 1.47 & 0.0 & 256.9 & 240.1 & 222.1 & 16.67 & 17.61 & 30.09 & 203.7 & 195.9 & 40.97 & 0.235 & 5.308 \\
\hline std dev & 2.21 & 0.56 & - & 0.99 & 1.00 & 1.16 & 0.16 & 0.23 & 0.45 & 43.1 & 28.4 & 13.87 & 0.041 & 0.786 \\
\hline $\max$ & 377.04 & 2.38 & 0.0 & 258.0 & 241.1 & 224.4 & 17.29 & 18.31 & 31.38 & 270.1 & 296.5 & 83.57 & 0.336 & 7.252 \\
\hline $\min$ & 369.075 & 0.40 & 0.0 & 255.6 & 237.9 & 221.0 & 16.34 & 17.11 & 29.18 & 148.5 & 133.8 & 21.75 & 0.185 & 3.214 \\
\hline
\end{tabular}

From: 01/06/2011 17:01:28

To: 01/06/2011 18:01:57

\begin{tabular}{|c|c|c|c|c|c|c|c|c|c|c|c|c|c|c|}
\hline & $\begin{array}{l}\text { plenum } \\
\text { exposed }\end{array}$ & $\begin{array}{l}\text { Feed } \\
\text { Rate }\end{array}$ & $\begin{array}{c}\text { Bubbling } \\
\text { Rate }\end{array}$ & $\begin{array}{l}\text { Heated } \\
\text { FC air }\end{array}$ & $\begin{array}{c}\text { FC } \\
\text { Outlet }\end{array}$ & $\begin{array}{c}\text { Transition } \\
\text { Outlet }\end{array}$ & $\begin{array}{l}\text { Stack } \\
\text { Flow }\end{array}$ & $\begin{array}{l}\text { Stack } \\
\text { Flow }\end{array}$ & $\begin{array}{l}\text { Stack } \\
\text { Flow }\end{array}$ & $\begin{array}{l}\mathrm{H}_{2-} \\
\mathrm{GC}\end{array}$ & $\begin{array}{c}\mathrm{H}_{2^{-}} \\
\text {Sensor }\end{array}$ & $\mathrm{CO}$ & $\mathrm{CO}_{2}$ & $\mathrm{H}_{2} \mathrm{O}$ \\
\hline & $\left({ }^{\circ} \mathrm{C}\right)$ & $(\mathrm{kg} / \mathrm{hr})$ & (lpm) & $\left({ }^{\circ} \mathrm{C}\right)$ & $\left({ }^{\circ} \mathrm{C}\right)$ & $\left({ }^{\circ} \mathrm{C}\right)$ & dscfm & scfm & acfm & ppm & $\mathrm{ppm}$ & ppm & vol $\%$ & vol $\%$ \\
\hline average & 296.22 & 1.40 & 0.0 & 256.7 & 226.0 & 208.7 & 26.97 & 27.63 & 45.91 & 92.2 & 110.5 & 25.0 & 0.120 & 2.380 \\
\hline std dev & 2.44 & 0.31 & - & 1.01 & 0.55 & 1.06 & 0.16 & 0.16 & 0.28 & 7.3 & 14.6 & 3.6 & 0.004 & 0.240 \\
\hline $\max$ & 302.095 & 2.23 & 0.0 & 258.3 & 226.9 & 210.4 & 27.26 & 27.84 & 46.37 & 96.0 & 156.9 & 33.6 & 0.131 & 2.892 \\
\hline $\min$ & 292.66 & 0.32 & 0.0 & 254.7 & 225.4 & 207.0 & 25.70 & 26.32 & 43.60 & 81.3 & 71.8 & 20.3 & 0.113 & 1.744 \\
\hline
\end{tabular}




\section{Baseline Feed, Bubbled}

From: 01/06/2011 05:37:08

To: 01/06/2011 06:25:10

\begin{tabular}{|c|c|c|c|c|c|c|c|c|c|c|c|c|c|c|}
\hline & $\begin{array}{l}\text { plenum } \\
\text { exposed }\end{array}$ & $\begin{array}{l}\text { Feed } \\
\text { Rate }\end{array}$ & $\begin{array}{c}\text { Bubbling } \\
\text { Rate }\end{array}$ & $\begin{array}{l}\text { Heated } \\
\text { FC air }\end{array}$ & $\begin{array}{c}\text { FC } \\
\text { Outlet }\end{array}$ & $\begin{array}{c}\text { Transition } \\
\text { Outlet }\end{array}$ & $\begin{array}{l}\text { Stack } \\
\text { Flow }\end{array}$ & $\begin{array}{l}\text { Stack } \\
\text { Flow }\end{array}$ & $\begin{array}{l}\text { Stack } \\
\text { Flow }\end{array}$ & $\begin{array}{l}\mathrm{H}_{2^{-}} \\
\mathrm{GC}\end{array}$ & $\begin{array}{c}\mathrm{H}_{2^{-}} \\
\text {Sensor }\end{array}$ & $\mathrm{CO}$ & $\mathrm{CO}_{2}$ & $\mathrm{H}_{2} \mathrm{O}$ \\
\hline & $\left({ }^{\circ} \mathrm{C}\right)$ & $(\mathrm{kg} / \mathrm{hr})$ & (lpm) & $\left({ }^{\circ} \mathrm{C}\right)$ & $\left({ }^{\circ} \mathrm{C}\right)$ & $\left({ }^{\circ} \mathrm{C}\right)$ & dscfm & scfm & acfm & ppm & ppm & ppm & vol\% & vol\% $\%$ \\
\hline average & 473.44 & 3.1 & 2.0 & 256.8 & 266.8 & 247.5 & 16.95 & 18.74 & 33.66 & 319.1 & 315.0 & 193.5 & 0.348 & 9.526 \\
\hline std dev & 6.21 & 0.28 & 0.27 & 0.83 & 2.80 & 0.93 & 0.17 & 0.16 & 0.30 & 53.5 & 36.9 & 19.2 & 0.021 & 0.354 \\
\hline $\max$ & 489.84 & 3.9 & 2.5 & 257.6 & 273.1 & 248.4 & 17.35 & 19.14 & 34.44 & 438.3 & 404.9 & 242.1 & 0.389 & 10.487 \\
\hline $\min$ & 463.02 & 2.4 & 1.8 & 255.2 & 262.2 & 246.0 & 16.47 & 18.28 & 32.89 & 272.0 & 235.7 & 155.2 & 0.305 & 8.902 \\
\hline
\end{tabular}

From: 01/06/2011 10:00:36

To: 01/06/2011 11:22:38

\begin{tabular}{|c|c|c|c|c|c|c|c|c|c|c|c|c|c|c|}
\hline & $\begin{array}{l}\text { plenum } \\
\text { exposed }\end{array}$ & $\begin{array}{l}\text { Feed } \\
\text { Rate }\end{array}$ & $\begin{array}{c}\text { Bubbling } \\
\text { Rate }\end{array}$ & $\begin{array}{l}\text { Heated } \\
\text { FC air }\end{array}$ & $\begin{array}{c}\text { FC } \\
\text { Outlet } \\
\end{array}$ & $\begin{array}{c}\text { Transition } \\
\text { Outlet }\end{array}$ & $\begin{array}{l}\text { Stack } \\
\text { Flow }\end{array}$ & $\begin{array}{l}\text { Stack } \\
\text { Flow }\end{array}$ & $\begin{array}{l}\text { Stack } \\
\text { Flow }\end{array}$ & $\begin{array}{l}\mathrm{H}_{2-}^{-} \\
\mathrm{GC} \\
\end{array}$ & $\begin{array}{c}\mathrm{H}_{2-} \\
\text { Sensor }\end{array}$ & $\mathrm{CO}$ & $\mathrm{CO}_{2}$ & $\mathrm{H}_{2} \mathrm{O}$ \\
\hline & $\left({ }^{\circ} \mathrm{C}\right)$ & $(\mathrm{kg} / \mathrm{hr})$ & (lpm) & $\left({ }^{\circ} \mathrm{C}\right)$ & $\left({ }^{\circ} \mathrm{C}\right)$ & $\left({ }^{\circ} \mathrm{C}\right)$ & dscfm & scfm & acfm & ppm & $\mathrm{ppm}$ & ppm & vol $\%$ & vol\% \\
\hline average & 409.81 & 3.13 & 0.2 & 256.8 & 252.8 & 234.3 & 16.85 & 18.37 & 32.17 & 314.0 & 309.4 & 97.5 & 0.303 & 8.220 \\
\hline std dev & 6.35 & 0.19 & 0.06 & 0.90 & 3.37 & 4.07 & 0.54 & 0.59 & 1.10 & 100.2 & 69.6 & 39.2 & 0.061 & 1.268 \\
\hline $\max$ & 423.01 & 3.84 & 0.5 & 257.9 & 258.6 & 253.5 & 20.89 & 22.91 & 40.30 & 569.9 & 499.1 & 177.7 & 0.432 & 11.583 \\
\hline $\min$ & 398.97 & 2.81 & 0.1 & 255.4 & 245.8 & 229.4 & 16.11 & 17.85 & 31.01 & 197.3 & 177.7 & 37.6 & 0.199 & 5.958 \\
\hline
\end{tabular}

From: 01/06/2011 15:13:00

To: 01/06/2011 16:07:25

\begin{tabular}{|c|c|c|c|c|c|c|c|c|c|c|c|c|c|c|}
\hline & $\begin{array}{l}\text { plenum } \\
\text { exposed }\end{array}$ & $\begin{array}{l}\text { Feed } \\
\text { Rate }\end{array}$ & $\begin{array}{c}\text { Bubbling } \\
\text { Rate }\end{array}$ & $\begin{array}{l}\text { Heated } \\
\text { FC air }\end{array}$ & $\begin{array}{c}\text { FC } \\
\text { Outlet }\end{array}$ & $\begin{array}{c}\text { Transition } \\
\text { Outlet }\end{array}$ & $\begin{array}{l}\text { Stack } \\
\text { Flow }\end{array}$ & $\begin{array}{l}\text { Stack } \\
\text { Flow }\end{array}$ & $\begin{array}{l}\text { Stack } \\
\text { Flow }\end{array}$ & $\begin{array}{l}\mathrm{H}_{2-} \\
\mathrm{GC}\end{array}$ & $\begin{array}{c}\mathrm{H}_{2^{-}} \\
\text {Sensor }\end{array}$ & $\mathrm{CO}$ & $\mathrm{CO}_{2}$ & $\mathrm{H}_{2} \mathrm{O}$ \\
\hline & $\left({ }^{\circ} \mathrm{C}\right)$ & $(\mathrm{kg} / \mathrm{hr})$ & (lpm) & $\left({ }^{\circ} \mathrm{C}\right)$ & $\left({ }^{\circ} \mathrm{C}\right)$ & $\left({ }^{\circ} \mathrm{C}\right)$ & dscfm & scfm & acfm & ppm & ppm & ppm & vol\% & vol $\%$ \\
\hline average & 334.39 & 3.05 & 1.6 & 256.7 & 234.8 & 222.6 & 26.66 & 28.28 & 48.39 & $\mathrm{n} / \mathrm{a}$ & 263.9 & 108.2 & 0.226 & 5.733 \\
\hline std dev & 2.67 & 0.23 & 0.02 & 1.06 & 1.14 & 1.64 & 0.19 & 0.15 & 0.25 & $\mathrm{n} / \mathrm{a}$ & 54.8 & 24.7 & 0.031 & 0.510 \\
\hline $\max$ & 338.62 & 3.75 & 1.6 & 258.3 & 236.5 & 226.2 & 27.27 & 28.70 & 49.09 & $\mathrm{n} / \mathrm{a}$ & 490.2 & 190.4 & 0.342 & 7.682 \\
\hline $\min$ & 328.07 & 2.69 & 1.5 & 254.7 & 231.7 & 218.9 & 25.86 & 28.01 & 47.80 & $\mathrm{n} / \mathrm{a}$ & 186.6 & 68.9 & 0.185 & 4.924 \\
\hline
\end{tabular}




\section{Glycolic Feed, Non-Bubbled}

From: $01 / 11 / 201112: 32: 10 \quad$ To: $\quad$ 01/11/2011 14:04:39

\begin{tabular}{|c|c|c|c|c|c|c|c|c|c|c|c|c|c|c|}
\hline & $\begin{array}{l}\text { plenum } \\
\text { exposed }\end{array}$ & $\begin{array}{l}\text { Feed } \\
\text { Rate }\end{array}$ & $\begin{array}{c}\text { Bubbling } \\
\text { Rate }\end{array}$ & $\begin{array}{l}\text { Heated } \\
\text { FC air }\end{array}$ & $\begin{array}{c}\text { FC } \\
\text { Outlet }\end{array}$ & $\begin{array}{c}\text { Transition } \\
\text { Outlet }\end{array}$ & $\begin{array}{l}\text { Stack } \\
\text { Flow }\end{array}$ & $\begin{array}{l}\text { Stack } \\
\text { Flow }\end{array}$ & $\begin{array}{l}\text { Stack } \\
\text { Flow }\end{array}$ & $\begin{array}{l}\mathrm{H}_{2^{-}} \\
\mathrm{GC} \\
\end{array}$ & $\begin{array}{c}\mathrm{H}_{2^{-}} \\
\text {Sensor }\end{array}$ & $\mathrm{CO}$ & $\mathrm{CO}_{2}$ & $\mathrm{H}_{2} \mathrm{O}$ \\
\hline & $\left({ }^{\circ} \mathrm{C}\right)$ & $(\mathrm{kg} / \mathrm{hr})$ & $(\mathrm{lpm})$ & $\left({ }^{\circ} \mathrm{C}\right)$ & $\left({ }^{\circ} \mathrm{C}\right)$ & $\left({ }^{\circ} \mathrm{C}\right)$ & dscfm & scfm & acfm & $\mathrm{ppm}$ & $\mathrm{ppm}$ & $\mathrm{ppm}$ & $\mathrm{vol} \%$ & vol $\%$ \\
\hline average & 471.22 & 1.70 & 0.0 & 246.1 & 300.0 & 245.1 & 18.71 & 19.60 & 24.48 & 37.59 & 27.77 & 29.83 & 0.240 & 4.523 \\
\hline std dev & 2.66 & 0.20 & - & 1.67 & 6.56 & 1.40 & 0.45 & 0.46 & 7.56 & 9.55 & 5.86 & 7.37 & 0.033 & 0.557 \\
\hline $\max$ & 476.67 & 2.14 & 0.0 & 248.7 & 311.7 & 250.3 & 23.44 & 24.37 & 43.78 & 51.54 & 43.26 & 54.67 & 0.330 & 5.752 \\
\hline $\min$ & 466.075 & 1.20 & 0.0 & 243.8 & 288.1 & 240.7 & 18.20 & 18.89 & 18.20 & 8.79 & 10.47 & 16.50 & 0.170 & 3.296 \\
\hline
\end{tabular}

From: 01/12/2011 11:39:49

To: 01/12/2011 13:01:51

\begin{tabular}{|c|c|c|c|c|c|c|c|c|c|c|c|c|c|c|}
\hline & $\begin{array}{l}\text { plenum } \\
\text { exposed }\end{array}$ & $\begin{array}{l}\text { Feed } \\
\text { Rate }\end{array}$ & $\begin{array}{c}\text { Bubbling } \\
\text { Rate }\end{array}$ & $\begin{array}{l}\text { Heated } \\
\text { FC air }\end{array}$ & $\begin{array}{c}\text { FC } \\
\text { Outlet }\end{array}$ & $\begin{array}{c}\text { Transition } \\
\text { Outlet }\end{array}$ & $\begin{array}{l}\text { Stack } \\
\text { Flow }\end{array}$ & $\begin{array}{l}\text { Stack } \\
\text { Flow }\end{array}$ & $\begin{array}{l}\text { Stack } \\
\text { Flow }\end{array}$ & $\begin{array}{l}\mathrm{H}_{2-} \\
\mathrm{GC} \\
\end{array}$ & $\begin{array}{c}\mathrm{H}_{2^{-}} \\
\text {Sensor }\end{array}$ & $\mathrm{CO}$ & $\mathrm{CO}_{2}$ & $\mathrm{H}_{2} \mathrm{O}$ \\
\hline & $\left({ }^{\circ} \mathrm{C}\right)$ & $(\mathrm{kg} / \mathrm{hr})$ & $(\mathrm{lpm})$ & $\left({ }^{\circ} \mathrm{C}\right)$ & $\left({ }^{\circ} \mathrm{C}\right)$ & $\left({ }^{\circ} \mathrm{C}\right)$ & dscfm & scfm & acfm & $\mathrm{ppm}$ & $\mathrm{ppm}$ & ppm & vol $\%$ & vol $\%$ \\
\hline average & 423.21 & 1.37 & 0.0 & 246.4 & 284.1 & 229.3 & 18.85 & 19.62 & 24.55 & 39.91 & 24.85 & 25.78 & 0.216 & 3.939 \\
\hline std dev & 2.19 & 0.15 & - & 1.22 & 6.58 & 2.94 & 0.76 & 0.79 & 7.60 & 5.10 & 6.49 & 4.584 & 0.020 & 0.241 \\
\hline $\max$ & 426.035 & 1.99 & 0.0 & 248.7 & 298.6 & 235.9 & 22.35 & 23.27 & 41.81 & 49.27 & 37.94 & 39.34 & 0.273 & 4.872 \\
\hline $\min$ & 415.705 & 1.14 & 0.0 & 244.1 & 276.2 & 225.1 & 17.86 & 18.58 & 17.86 & 30.44 & 2.66 & 19.37 & 0.183 & 3.484 \\
\hline
\end{tabular}

From: $01 / 12 / 2011$ 14:32:22 $\quad$ To: 01/12/2011 15:32:23

\begin{tabular}{|c|c|c|c|c|c|c|c|c|c|c|c|c|c|c|}
\hline & $\begin{array}{l}\text { plenum } \\
\text { exposed }\end{array}$ & $\begin{array}{l}\text { Feed } \\
\text { Rate }\end{array}$ & $\begin{array}{c}\text { Bubbling } \\
\text { Rate }\end{array}$ & $\begin{array}{l}\text { Heated } \\
\text { FC air }\end{array}$ & $\begin{array}{c}\text { FC } \\
\text { Outlet } \\
\end{array}$ & $\begin{array}{c}\text { Transition } \\
\text { Outlet }\end{array}$ & $\begin{array}{l}\text { Stack } \\
\text { Flow }\end{array}$ & $\begin{array}{l}\text { Stack } \\
\text { Flow }\end{array}$ & $\begin{array}{l}\text { Stack } \\
\text { Flow } \\
\end{array}$ & $\begin{array}{l}\mathrm{H}_{2-} \\
\mathrm{GC} \\
\end{array}$ & $\begin{array}{c}\mathrm{H}_{2^{-}} \\
\text {Sensor }\end{array}$ & $\mathrm{CO}$ & $\mathrm{CO}_{2}$ & $\mathrm{H}_{2} \mathrm{O}$ \\
\hline & $\left({ }^{\circ} \mathrm{C}\right)$ & $(\mathrm{kg} / \mathrm{hr})$ & (lpm) & $\left({ }^{\circ} \mathrm{C}\right)$ & $\left({ }^{\circ} \mathrm{C}\right)$ & $\left({ }^{\circ} \mathrm{C}\right)$ & dscfm & scfm & acfm & $\mathrm{ppm}$ & $\mathrm{ppm}$ & ppm & vol\% & $\mathrm{vol} \%$ \\
\hline average & 374.24 & 1.37 & 0.0 & 246.2 & 244.7 & 231.8 & 24.70 & 25.47 & 31.93 & 31.74 & 27.95 & 17.92 & 0.170 & 3.022 \\
\hline std dev & 3.08 & 0.19 & - & 1.37 & 1.97 & 2.50 & 0.50 & 0.48 & 9.72 & 6.41 & 5.87 & 4.77 & 0.018 & 0.276 \\
\hline $\max$ & 381.745 & 1.98 & 0.0 & 248.8 & 251.3 & 241.3 & 26.53 & 27.33 & 49.01 & 47.66 & 41.22 & 34.92 & 0.216 & 3.940 \\
\hline $\min$ & 364.315 & 0.70 & 0.0 & 244.1 & 242.8 & 227.8 & 23.84 & 24.55 & 23.84 & 25.29 & 8.11 & 11.54 & 0.145 & 2.676 \\
\hline
\end{tabular}


From: 01/12/2011 17:00:53

To: 01/12/2011 18:07:26

\begin{tabular}{|c|c|c|c|c|c|c|c|c|c|c|c|c|c|c|}
\hline & $\begin{array}{l}\text { plenum } \\
\text { exposed }\end{array}$ & $\begin{array}{l}\text { Feed } \\
\text { Rate }\end{array}$ & $\begin{array}{c}\text { Bubbling } \\
\text { Rate }\end{array}$ & $\begin{array}{l}\text { Heated } \\
\text { FC air }\end{array}$ & $\begin{array}{c}\text { FC } \\
\text { Outlet }\end{array}$ & $\begin{array}{c}\text { Transition } \\
\text { Outlet }\end{array}$ & $\begin{array}{l}\text { Stack } \\
\text { Flow }\end{array}$ & $\begin{array}{l}\text { Stack } \\
\text { Flow }\end{array}$ & $\begin{array}{l}\text { Stack } \\
\text { Flow }\end{array}$ & $\begin{array}{l}\mathrm{H}_{2^{-}} \\
\mathrm{GC}\end{array}$ & $\begin{array}{c}\mathrm{H}_{2^{-}} \\
\text {Sensor }\end{array}$ & $\mathrm{CO}$ & $\mathrm{CO}_{2}$ & $\mathrm{H}_{2} \mathrm{O}$ \\
\hline & $\left({ }^{\circ} \mathrm{C}\right)$ & $(\mathrm{kg} / \mathrm{hr})$ & $(\mathrm{lpm})$ & $\left({ }^{\circ} \mathrm{C}\right)$ & $\left({ }^{\circ} \mathrm{C}\right)$ & $\left({ }^{\circ} \mathrm{C}\right)$ & dscfm & scfm & acfm & ppm & ppm & $\mathrm{ppm}$ & vol\% & vol $\%$ \\
\hline average & 323.17 & 1.28 & 0.0 & 246.4 & 232.0 & 219.1 & 26.72 & 27.41 & 34.42 & 27.12 & 28.28 & 15.01 & 0.146 & 2.519 \\
\hline std dev & 6.62 & 0.21 & - & 0.97 & 1.86 & 2.23 & 0.84 & 0.83 & 10.47 & 9.51 & 4.13 & 6.05 & 0.025 & 0.358 \\
\hline $\max$ & 332.39 & 1.53 & 0.0 & 247.9 & 237.0 & 223.3 & 29.63 & 30.27 & 54.20 & 46.85 & 39.01 & 39.62 & 0.257 & 4.215 \\
\hline $\min$ & 295.225 & 0.34 & 0.0 & 244.8 & 228.5 & 214.4 & 24.04 & 24.81 & 24.04 & 15.34 & 14.51 & 8.55 & 0.114 & 2.037 \\
\hline
\end{tabular}

\section{Glycolic Feed, Bubbled}

From: 01/13/2011 10:34:24

To: 01/13/2011 11:10:24

\begin{tabular}{|c|c|c|c|c|c|c|c|c|c|c|c|c|c|c|}
\hline & $\begin{array}{l}\text { plenum } \\
\text { exposed }\end{array}$ & $\begin{array}{l}\text { Feed } \\
\text { Rate }\end{array}$ & $\begin{array}{c}\text { Bubbling } \\
\text { Rate }\end{array}$ & $\begin{array}{l}\text { Heated } \\
\text { FC air }\end{array}$ & $\begin{array}{c}\text { FC } \\
\text { Outlet }\end{array}$ & $\begin{array}{c}\text { Transition } \\
\text { Outlet }\end{array}$ & $\begin{array}{l}\text { Stack } \\
\text { Flow }\end{array}$ & $\begin{array}{l}\text { Stack } \\
\text { Flow }\end{array}$ & $\begin{array}{l}\text { Stack } \\
\text { Flow }\end{array}$ & $\mathrm{H}_{2}$-GC & $\begin{array}{c}\mathrm{H}_{2^{-}} \\
\text {Sensor }\end{array}$ & $\mathrm{CO}$ & $\mathrm{CO}_{2}$ & $\mathrm{H}_{2} \mathrm{O}$ \\
\hline & $\left({ }^{\circ} \mathrm{C}\right)$ & $(\mathrm{kg} / \mathrm{hr})$ & (lpm) & $\left({ }^{\circ} \mathrm{C}\right)$ & $\left({ }^{\circ} \mathrm{C}\right)$ & $\left({ }^{\circ} \mathrm{C}\right)$ & dscfm & scfm & $\mathrm{acfm}$ & ppm & $\mathrm{ppm}$ & ppm & vol $\%$ & vol\% \\
\hline average & 441.84 & 2.84 & 2.8 & 246.7 & 235.7 & 231.6 & 17.97 & 19.35 & 24.01 & 111.65 & 53.11 & 75.22 & 0.345 & 7.115 \\
\hline std dev & 2.03 & 0.09 & 0.01 & 0.61 & 2.88 & 2.71 & 0.69 & 0.73 & 7.66 & 67.82 & 12.64 & 33.63 & 0.091 & 0.865 \\
\hline $\max$ & 444.845 & 3.01 & 2.8 & 247.5 & 242.4 & 239.3 & 21.48 & 23.08 & 41.35 & 237.96 & 108.36 & 199.39 & 0.648 & 9.514 \\
\hline $\min$ & 436.6 & 2.71 & 2.7 & 246.1 & 231.7 & 228.6 & 16.34 & 17.71 & 16.34 & 61.86 & 33.28 & 29.03 & 0.191 & 5.534 \\
\hline
\end{tabular}

From: 01/13/2011 11:22:24

To: 01/13/2011 12:26:51

\begin{tabular}{|c|c|c|c|c|c|c|c|c|c|c|c|c|c|c|}
\hline & $\begin{array}{l}\text { plenum } \\
\text { exposed }\end{array}$ & $\begin{array}{l}\text { Feed } \\
\text { Rate }\end{array}$ & $\begin{array}{c}\text { Bubbling } \\
\text { Rate }\end{array}$ & $\begin{array}{l}\text { Heated } \\
\text { FC air }\end{array}$ & $\begin{array}{c}\text { FC } \\
\text { Outlet }\end{array}$ & $\begin{array}{c}\text { Transition } \\
\text { Outlet }\end{array}$ & $\begin{array}{l}\text { Stack } \\
\text { Flow }\end{array}$ & $\begin{array}{l}\text { Stack } \\
\text { Flow }\end{array}$ & $\begin{array}{l}\text { Stack } \\
\text { Flow }\end{array}$ & $\mathrm{H}_{2}-\mathrm{GC}$ & $\begin{array}{c}\mathrm{H}_{2^{-}} \\
\text {Sensor }\end{array}$ & $\mathrm{CO}$ & $\mathrm{CO}_{2}$ & $\mathrm{H}_{2} \mathrm{O}$ \\
\hline & $\left({ }^{\circ} \mathrm{C}\right)$ & $(\mathrm{kg} / \mathrm{hr})$ & (lpm) & $\left({ }^{\circ} \mathrm{C}\right)$ & $\left({ }^{\circ} \mathrm{C}\right)$ & $\left({ }^{\circ} \mathrm{C}\right)$ & dscfm & scfm & acfm & ppm & ppm & ppm & vol $\%$ & vol\% $\%$ \\
\hline average & 385.04 & 2.85 & 2.8 & 246.9 & 233.0 & 234.6 & 20.84 & 22.35 & 27.77 & 85.57 & 63.07 & 76.97 & 0.350 & 6.739 \\
\hline std dev & 3.23 & 0.13 & 0.03 & 0.71 & 1.76 & 2.97 & 1.19 & 1.25 & 8.91 & 31.27 & 14.47 & 36.01 & 0.085 & 1.146 \\
\hline $\max$ & 391.6 & 3.11 & 2.9 & 248.2 & 236.3 & 240.6 & 23.53 & 25.26 & 45.39 & 146.37 & 103.35 & 157.81 & 0.552 & 9.589 \\
\hline $\min$ & 376.225 & 2.42 & 2.7 & 246.1 & 230.2 & 229.5 & 19.16 & 20.47 & 19.16 & 51.97 & 39.54 & 24.34 & 0.204 & 4.929 \\
\hline
\end{tabular}


From: 01/13/2011 14:17:40

To: 01/13/2011 14:57:40

\begin{tabular}{|c|c|c|c|c|c|c|c|c|c|c|c|c|c|c|}
\hline & $\begin{array}{l}\text { plenum } \\
\text { exposed }\end{array}$ & $\begin{array}{l}\text { Feed } \\
\text { Rate }\end{array}$ & $\begin{array}{c}\text { Bubbling } \\
\text { Rate }\end{array}$ & $\begin{array}{l}\text { Heated } \\
\text { FC air }\end{array}$ & $\begin{array}{c}\text { FC } \\
\text { Outlet }\end{array}$ & $\begin{array}{c}\text { Transition } \\
\text { Outlet }\end{array}$ & $\begin{array}{l}\text { Stack } \\
\text { Flow }\end{array}$ & $\begin{array}{l}\text { Stack } \\
\text { Flow }\end{array}$ & $\begin{array}{l}\text { Stack } \\
\text { Flow }\end{array}$ & $\mathrm{H}_{2}-\mathrm{GC}$ & $\begin{array}{c}\mathrm{H}_{2^{-}} \\
\text {Sensor }\end{array}$ & $\mathrm{CO}$ & $\mathrm{CO}_{2}$ & $\mathrm{H}_{2} \mathrm{O}$ \\
\hline & $\left({ }^{\circ} \mathrm{C}\right)$ & $(\mathrm{kg} / \mathrm{hr})$ & (lpm) & $\left({ }^{\circ} \mathrm{C}\right)$ & $\left({ }^{\circ} \mathrm{C}\right)$ & $\left({ }^{\circ} \mathrm{C}\right)$ & dscfm & scfm & $\mathrm{acfm}$ & $\mathrm{ppm}$ & $\mathrm{ppm}$ & $\mathrm{ppm}$ & vol $\%$ & vol $\%$ \\
\hline average & 319.69 & 2.77 & 2.7 & 246.7 & 211.5 & 222.0 & 27.56 & 28.86 & 36.06 & 54.61 & 74.74 & 47.00 & 0.246 & 4.484 \\
\hline std dev & 3.75 & 0.08 & 0.04 & 1.00 & 1.00 & 1.16 & 1.20 & 1.27 & 11.25 & 11.59 & 8.33 & 11.73 & 0.028 & 0.390 \\
\hline $\max$ & 327.45 & 2.96 & 2.8 & 247.9 & 213.7 & 224.1 & 30.61 & 31.96 & 57.41 & 80.14 & 97.38 & 74.23 & 0.318 & 5.520 \\
\hline $\min$ & 313.985 & 2.62 & 2.7 & 245.4 & 210.0 & 220.4 & 26.65 & 27.94 & 26.65 & 45.95 & 56.95 & 28.42 & 0.205 & 3.691 \\
\hline
\end{tabular}

From: 01/13/2011 15:42:22

To: 01/13/2011 16:58:29

\begin{tabular}{|c|c|c|c|c|c|c|c|c|c|c|c|c|c|c|}
\hline & $\begin{array}{l}\text { plenum } \\
\text { exposed }\end{array}$ & $\begin{array}{l}\text { Feed } \\
\text { Rate }\end{array}$ & $\begin{array}{c}\text { Bubbling } \\
\text { Rate }\end{array}$ & $\begin{array}{l}\text { Heated } \\
\text { FC air }\end{array}$ & $\begin{array}{c}\text { FC } \\
\text { Outlet }\end{array}$ & $\begin{array}{c}\text { Transition } \\
\text { Outlet }\end{array}$ & $\begin{array}{l}\text { Stack } \\
\text { Flow }\end{array}$ & $\begin{array}{l}\text { Stack } \\
\text { Flow }\end{array}$ & $\begin{array}{l}\text { Stack } \\
\text { Flow }\end{array}$ & $\mathrm{H}_{2}-\mathrm{GC}$ & $\begin{array}{c}\mathrm{H}_{2-} \\
\text { Sensor }\end{array}$ & $\mathrm{CO}$ & $\mathrm{CO}_{2}$ & $\mathrm{H}_{2} \mathrm{O}$ \\
\hline & $\left({ }^{\circ} \mathrm{C}\right)$ & $(\mathrm{kg} / \mathrm{hr})$ & $(\mathrm{lpm})$ & $\left({ }^{\circ} \mathrm{C}\right)$ & $\left({ }^{\circ} \mathrm{C}\right)$ & $\left({ }^{\circ} \mathrm{C}\right)$ & dscfm & $\mathrm{scfm}$ & acfm & $\mathrm{ppm}$ & $\mathrm{ppm}$ & ppm & vol\% & vol\% \\
\hline average & 257.00 & 2.95 & 2.5 & 246.4 & 211.3 & 197.3 & 30.47 & 31.80 & 39.76 & 57.86 & 81.96 & 50.77 & 0.236 & 4.170 \\
\hline std dev & 7.65 & 0.14 & 0.30 & 0.82 & 1.59 & 2.11 & 0.54 & 0.54 & 12.24 & 15.84 & 10.90 & 21.12 & 0.063 & 0.876 \\
\hline $\max$ & 280.17 & 3.22 & 2.7 & 248.0 & 214.6 & 202.0 & 31.99 & 33.46 & 59.88 & 84.33 & 127.89 & 145.51 & 0.554 & 8.242 \\
\hline $\min$ & 243.49 & 2.61 & 1.7 & 244.4 & 208.2 & 192.8 & 29.37 & 30.72 & 29.37 & 23.20 & 59.90 & 15.86 & 0.154 & 2.560 \\
\hline
\end{tabular}

\section{Sugar Feed, Non-Bubbled}

From: 01/19/2011 14:57:59

To: 01/19/2011 16:23:33

\begin{tabular}{|c|c|c|c|c|c|c|c|c|c|c|c|c|c|c|}
\hline & $\begin{array}{l}\text { plenum } \\
\text { exposed }\end{array}$ & $\begin{array}{l}\text { Feed } \\
\text { Rate }\end{array}$ & $\begin{array}{c}\text { Bubbling } \\
\text { Rate }\end{array}$ & $\begin{array}{l}\text { Heated } \\
\text { FC air }\end{array}$ & $\begin{array}{c}\text { FC } \\
\text { Outlet }\end{array}$ & $\begin{array}{c}\text { Transition } \\
\text { Outlet }\end{array}$ & $\begin{array}{l}\text { Stack } \\
\text { Flow }\end{array}$ & $\begin{array}{l}\text { Stack } \\
\text { Flow }\end{array}$ & $\begin{array}{l}\text { Stack } \\
\text { Flow }\end{array}$ & $\mathrm{H}_{2}-\mathrm{GC}$ & $\begin{array}{c}\mathrm{H}_{2^{-}} \\
\text {Sensor }\end{array}$ & $\mathrm{CO}$ & $\mathrm{CO}_{2}$ & $\mathrm{H}_{2} \mathrm{O}$ \\
\hline & $\left({ }^{\circ} \mathrm{C}\right)$ & $(\mathrm{kg} / \mathrm{hr})$ & (lpm) & $\left({ }^{\circ} \mathrm{C}\right)$ & $\left({ }^{\circ} \mathrm{C}\right)$ & $\left({ }^{\circ} \mathrm{C}\right)$ & dscfm & scfm & acfm & ppm & $\mathrm{ppm}$ & ppm & vol\% & vol $\%$ \\
\hline average & 503.85 & 1.41 & 0.0 & 246.1 & 278.2 & 237.2 & 18.38 & 19.48 & 23.94 & 45.68 & 41.58 & 65.12 & 0.212 & 5.622 \\
\hline std dev & 3.09 & 0.22 & - & 1.27 & 2.54 & 2.87 & 0.47 & 0.50 & 7.14 & 9.44 & 5.15 & 9.36 & 0.015 & 0.415 \\
\hline $\max$ & 509.84 & 1.96 & 0.0 & 248.3 & 286.4 & 252.5 & 21.79 & 23.15 & 41.22 & 71.31 & 57.23 & 90.23 & 0.265 & 6.653 \\
\hline $\min$ & 497.355 & 0.80 & 0.0 & 244.8 & 273.3 & 233.1 & 17.27 & 18.29 & 17.27 & 30.90 & 26.14 & 46.98 & 0.180 & 4.605 \\
\hline
\end{tabular}


From: 01/19/2011 22:52:54

To: $01 / 19 / 201123: 24: 54$

\begin{tabular}{|c|c|c|c|c|c|c|c|c|c|c|c|c|c|c|}
\hline & $\begin{array}{l}\text { plenum } \\
\text { exposed }\end{array}$ & $\begin{array}{l}\text { Feed } \\
\text { Rate }\end{array}$ & $\begin{array}{c}\text { Bubbling } \\
\text { Rate }\end{array}$ & $\begin{array}{l}\text { Heated } \\
\text { FC air }\end{array}$ & $\begin{array}{c}\text { FC } \\
\text { Outlet }\end{array}$ & $\begin{array}{c}\text { Transition } \\
\text { Outlet }\end{array}$ & $\begin{array}{l}\text { Stack } \\
\text { Flow }\end{array}$ & $\begin{array}{l}\text { Stack } \\
\text { Flow }\end{array}$ & $\begin{array}{l}\text { Stack } \\
\text { Flow }\end{array}$ & $\mathrm{H}_{2}$-GC & $\begin{array}{c}\mathrm{H}_{2^{-}} \\
\text {Sensor }\end{array}$ & $\mathrm{CO}$ & $\mathrm{CO}_{2}$ & $\mathrm{H}_{2} \mathrm{O}$ \\
\hline & $\left({ }^{\circ} \mathrm{C}\right)$ & $(\mathrm{kg} / \mathrm{hr})$ & (lpm) & $\left({ }^{\circ} \mathrm{C}\right)$ & $\left({ }^{\circ} \mathrm{C}\right)$ & $\left({ }^{\circ} \mathrm{C}\right)$ & dscfm & scfm & acfm & $\mathrm{ppm}$ & $\mathrm{ppm}$ & $\mathrm{ppm}$ & vol $\%$ & $\mathrm{vol} \%$ \\
\hline average & 499.11 & 1.40 & 0.0 & 246.5 & 273.4 & 235.0 & 18.60 & 19.52 & 24.01 & 38.63 & 29.65 & 55.63 & 0.183 & 4.745 \\
\hline std dev & 1.72 & 0.10 & - & 0.66 & 1.54 & 4.58 & 0.91 & 0.97 & 7.15 & 5.50 & 3.76 & 11.67 & 0.09 & 0.512 \\
\hline $\max$ & 502.64 & 1.67 & 0.0 & 248.0 & 277.5 & 251.1 & 22.11 & 23.31 & 40.86 & 47.06 & 36.49 & 73.24 & 0.212 & 5.685 \\
\hline $\min$ & 496.72 & 1.27 & 0.0 & 245.9 & 271.5 & 232.6 & 16.95 & 17.60 & 16.95 & 31.80 & 22.18 & 26.45 & 0.130 & 3.369 \\
\hline
\end{tabular}

From: 01/20/2011 07:47:01

To: 01/20/2011 08:39:01

\begin{tabular}{|c|c|c|c|c|c|c|c|c|c|c|c|c|c|c|}
\hline & $\begin{array}{l}\text { plenum } \\
\text { exposed }\end{array}$ & $\begin{array}{l}\text { Feed } \\
\text { Rate }\end{array}$ & $\begin{array}{c}\text { Bubbling } \\
\text { Rate }\end{array}$ & $\begin{array}{l}\text { Heated } \\
\text { FC air }\end{array}$ & $\begin{array}{c}\text { FC } \\
\text { Outlet }\end{array}$ & $\begin{array}{c}\text { Transition } \\
\text { Outlet }\end{array}$ & $\begin{array}{l}\text { Stack } \\
\text { Flow }\end{array}$ & $\begin{array}{l}\text { Stack } \\
\text { Flow }\end{array}$ & $\begin{array}{l}\text { Stack } \\
\text { Flow }\end{array}$ & $\mathrm{H}_{2}-\mathrm{GC}$ & $\begin{array}{c}\mathrm{H}_{2^{-}} \\
\text {Sensor }\end{array}$ & $\mathrm{CO}$ & $\mathrm{CO}_{2}$ & $\mathrm{H}_{2} \mathrm{O}$ \\
\hline & $\left({ }^{\circ} \mathrm{C}\right)$ & $(\mathrm{kg} / \mathrm{hr})$ & (lpm) & $\left({ }^{\circ} \mathrm{C}\right)$ & $\left({ }^{\circ} \mathrm{C}\right)$ & $\left({ }^{\circ} \mathrm{C}\right)$ & dscfm & scfm & acfm & ppm & $\mathrm{ppm}$ & ppm & vol $\%$ & vol\% \\
\hline average & 474.31 & 1.40 & 0.0 & 247.0 & 266.8 & 229.6 & 18.49 & 19.30 & 23.64 & 40.47 & 26.00 & 32.99 & 0.169 & 4.196 \\
\hline std dev & 1.94 & 0.15 & - & 0.62 & 1.08 & 0.57 & 0.11 & 0.10 & 6.74 & 8.75 & 5.51 & 6.72 & 0.017 & 0.415 \\
\hline $\max$ & 477.955 & 1.73 & 0.0 & 247.9 & 268.8 & 230.3 & 18.78 & 19.58 & 33.63 & 59.17 & 42.19 & 51.90 & 0.211 & 5.041 \\
\hline $\min$ & 469.38 & 1.13 & 0.0 & 245.5 & 265.1 & 229.0 & 18.23 & 19.08 & 18.23 & 31.33 & 10.16 & 21.14 & 0.128 & 3.281 \\
\hline
\end{tabular}

From: 01/20/2011 10:55:03

To: 01/20/2011 12:03:03

\begin{tabular}{|c|c|c|c|c|c|c|c|c|c|c|c|c|c|c|}
\hline & $\begin{array}{l}\text { plenum } \\
\text { exposed }\end{array}$ & $\begin{array}{l}\text { Feed } \\
\text { Rate }\end{array}$ & $\begin{array}{c}\text { Bubbling } \\
\text { Rate }\end{array}$ & $\begin{array}{l}\text { Heated } \\
\text { FC air }\end{array}$ & $\begin{array}{c}\text { FC } \\
\text { Outlet }\end{array}$ & $\begin{array}{c}\text { Transition } \\
\text { Outlet }\end{array}$ & $\begin{array}{l}\text { Stack } \\
\text { Flow }\end{array}$ & $\begin{array}{l}\text { Stack } \\
\text { Flow }\end{array}$ & $\begin{array}{l}\text { Stack } \\
\text { Flow }\end{array}$ & $\mathrm{H}_{2}-\mathrm{GC}$ & $\begin{array}{c}\mathrm{H}_{2^{-}} \\
\text {Sensor }\end{array}$ & $\mathrm{CO}$ & $\mathrm{CO}_{2}$ & $\mathrm{H}_{2} \mathrm{O}$ \\
\hline & $\left({ }^{\circ} \mathrm{C}\right)$ & $(\mathrm{kg} / \mathrm{hr})$ & (lpm) & $\left({ }^{\circ} \mathrm{C}\right)$ & $\left({ }^{\circ} \mathrm{C}\right)$ & $\left({ }^{\circ} \mathrm{C}\right)$ & dscfm & scfm & acfm & ppm & $\mathrm{ppm}$ & ppm & vol\% & vol\% \\
\hline average & 428.24 & 1.39 & 0.0 & 246.6 & 262.9 & 236.1 & 21.29 & 22.22 & 27.40 & 41.85 & 29.68 & 23.91 & 0.170 & 4.165 \\
\hline std dev & 2.71 & 0.18 & \#DIV/0! & 0.95 & 1.42 & 1.69 & 0.31 & 0.31 & 8.00 & 10.46 & 5.57 & 5.16 & 0.014 & 0.455 \\
\hline $\max$ & 435.905 & 2.16 & 0.0 & 247.9 & 266.5 & 239.8 & 21.83 & 22.73 & 39.81 & 58.91 & 43.28 & 41.75 & 0.211 & 5.605 \\
\hline $\min$ & 421.26 & 1.12 & 0.0 & 245.5 & 260.5 & 232.7 & 20.08 & 21.06 & 20.08 & 26.52 & 15.18 & 14.35 & 0.140 & 3.341 \\
\hline
\end{tabular}


From: 01/20/2011 15:53:27

To: $01 / 20 / 2011$ 16:35:28

\begin{tabular}{|c|c|c|c|c|c|c|c|c|c|c|c|c|c|c|}
\hline & $\begin{array}{l}\text { plenum } \\
\text { exposed }\end{array}$ & $\begin{array}{l}\text { Feed } \\
\text { Rate }\end{array}$ & $\begin{array}{c}\text { Bubbling } \\
\text { Rate }\end{array}$ & $\begin{array}{l}\text { Heated } \\
\text { FC air }\end{array}$ & $\begin{array}{c}\text { FC } \\
\text { Outlet }\end{array}$ & $\begin{array}{c}\text { Transition } \\
\text { Outlet }\end{array}$ & $\begin{array}{l}\text { Stack } \\
\text { Flow }\end{array}$ & $\begin{array}{l}\text { Stack } \\
\text { Flow }\end{array}$ & $\begin{array}{l}\text { Stack } \\
\text { Flow }\end{array}$ & $\mathrm{H}_{2}$-GC & $\begin{array}{c}\mathrm{H}_{2^{-}} \\
\text {Sensor }\end{array}$ & $\mathrm{CO}$ & $\mathrm{CO}_{2}$ & $\mathrm{H}_{2} \mathrm{O}$ \\
\hline & $\left({ }^{\circ} \mathrm{C}\right)$ & $(\mathrm{kg} / \mathrm{hr})$ & (lpm) & $\left({ }^{\circ} \mathrm{C}\right)$ & $\left({ }^{\circ} \mathrm{C}\right)$ & $\left({ }^{\circ} \mathrm{C}\right)$ & dscfm & $\mathrm{scfm}$ & acfm & $\mathrm{ppm}$ & $\mathrm{ppm}$ & ppm & vol\% & vol\% \\
\hline average & 374.79 & 1.37 & 0.0 & 246.2 & 245.6 & 227.1 & 22.79 & 23.70 & 29.01 & 35.30 & 32.57 & 16.80 & 0.160 & 3.839 \\
\hline std dev & 1.83 & 0.13 & \#DIV/0! & 0.77 & 1.43 & 0.59 & 0.39 & 0.37 & 8.18 & 8.68 & 4.83 & 2.81 & 0.014 & 0.339 \\
\hline $\max$ & 377.5 & 1.68 & 0.0 & 248.1 & 248.7 & 228.1 & 23.14 & 24.08 & 41.20 & 48.34 & 42.87 & 22.04 & 0.190 & 4.432 \\
\hline $\min$ & 371.28 & 1.03 & 0.0 & 245.6 & 244.1 & 226.0 & 22.06 & 22.98 & 22.06 & 19.14 & 21.34 & 11.39 & 0.127 & 3.305 \\
\hline
\end{tabular}

From: 01/20/2011 19:23:32

To: 01/20/2011 20:42:05

\begin{tabular}{|c|c|c|c|c|c|c|c|c|c|c|c|c|c|c|}
\hline & $\begin{array}{l}\text { plenum } \\
\text { exposed }\end{array}$ & $\begin{array}{l}\text { Feed } \\
\text { Rate }\end{array}$ & $\begin{array}{c}\text { Bubbling } \\
\text { Rate }\end{array}$ & $\begin{array}{l}\text { Heated } \\
\text { FC air }\end{array}$ & $\begin{array}{c}\text { FC } \\
\text { Outlet }\end{array}$ & $\begin{array}{c}\text { Transition } \\
\text { Outlet }\end{array}$ & $\begin{array}{l}\text { Stack } \\
\text { Flow }\end{array}$ & $\begin{array}{l}\text { Stack } \\
\text { Flow }\end{array}$ & $\begin{array}{l}\text { Stack } \\
\text { Flow }\end{array}$ & $\mathrm{H}_{2}-\mathrm{GC}$ & $\begin{array}{c}\mathrm{H}_{2^{-}} \\
\text {Sensor }\end{array}$ & $\mathrm{CO}$ & $\mathrm{CO}_{2}$ & $\mathrm{H}_{2} \mathrm{O}$ \\
\hline & $\left({ }^{\circ} \mathrm{C}\right)$ & $(\mathrm{kg} / \mathrm{hr})$ & (lpm) & $\left({ }^{\circ} \mathrm{C}\right)$ & $\left({ }^{\circ} \mathrm{C}\right)$ & $\left({ }^{\circ} \mathrm{C}\right)$ & dscfm & scfm & acfm & ppm & $\mathrm{ppm}$ & ppm & vol\% & vol\% \\
\hline average & 331.66 & 1.29 & 0.0 & 246.2 & 227.2 & 212.8 & 25.88 & 26.72 & 32.33 & 31.41 & 33.22 & 12.63 & 0.134 & 3.177 \\
\hline std dev & 3.41 & 0.22 & - & 1.23 & 0.96 & 1.27 & 0.09 & 0.08 & 8.54 & 5.22 & 3.95 & 2.00 & 0.008 & 0.241 \\
\hline $\max$ & 337.85 & 1.63 & 0.0 & 248.2 & 228.6 & 214.6 & 26.10 & 26.90 & 44.81 & 44.37 & 41.58 & 20.55 & 0.155 & 3.878 \\
\hline $\min$ & 324.39 & 0.54 & 0.0 & 244.2 & 225.7 & 210.7 & 25.62 & 26.54 & 25.62 & 26.44 & 22.39 & 9.21 & 0.123 & 2.754 \\
\hline
\end{tabular}

From: 01/20/2011 23:34:54

To: 01/21/2011 00:42:55

\begin{tabular}{|c|c|c|c|c|c|c|c|c|c|c|c|c|c|c|}
\hline & $\begin{array}{l}\text { plenum } \\
\text { exposed }\end{array}$ & $\begin{array}{l}\text { Feed } \\
\text { Rate }\end{array}$ & $\begin{array}{c}\text { Bubbling } \\
\text { Rate }\end{array}$ & $\begin{array}{l}\text { Heated } \\
\text { FC air }\end{array}$ & $\begin{array}{c}\text { FC } \\
\text { Outlet }\end{array}$ & $\begin{array}{c}\text { Transition } \\
\text { Outlet }\end{array}$ & $\begin{array}{l}\text { Stack } \\
\text { Flow }\end{array}$ & $\begin{array}{l}\text { Stack } \\
\text { Flow }\end{array}$ & $\begin{array}{l}\text { Stack } \\
\text { Flow }\end{array}$ & $\mathrm{H}_{2}-\mathrm{GC}$ & $\begin{array}{c}\mathrm{H}_{2^{-}} \\
\text {Sensor }\end{array}$ & $\mathrm{CO}$ & $\mathrm{CO}_{2}$ & $\mathrm{H}_{2} \mathrm{O}$ \\
\hline & $\left({ }^{\circ} \mathrm{C}\right)$ & $(\mathrm{kg} / \mathrm{hr})$ & (lpm) & $\left({ }^{\circ} \mathrm{C}\right)$ & $\left({ }^{\circ} \mathrm{C}\right)$ & $\left({ }^{\circ} \mathrm{C}\right)$ & dscfm & $\mathrm{scfm}$ & $\mathrm{acfm}$ & $\mathrm{ppm}$ & $\mathrm{ppm}$ & ppm & $\mathrm{vol} \%$ & $\mathrm{vol} \%$ \\
\hline average & 241.44 & 1.30 & 0.0 & 245.8 & 200.6 & 190.7 & 32.09 & 32.87 & 39.03 & 25.20 & 34.39 & 7.92 & 0.106 & 2.385 \\
\hline std dev & 2.60 & 0.13 & - & 1.75 & 0.96 & 1.04 & 0.14 & 0.12 & 9.28 & 4.94 & 3.79 & 1.23 & 0.006 & 0.157 \\
\hline $\max$ & 247.69 & 1.61 & 0.0 & 248.3 & 202.0 & 192.7 & 33.23 & 33.99 & 53.96 & 32.59 & 46.17 & 10.90 & 0.119 & 2.664 \\
\hline $\min$ & 237.855 & 1.05 & 0.0 & 243.3 & 198.4 & 189.0 & 31.78 & 32.58 & 31.78 & 19.04 & 22.18 & 4.90 & 0.087 & 2.006 \\
\hline
\end{tabular}




\section{Sugar Feed, Bubbled}

From: 01/21/2011 02:37:41

To: 01/21/2011 03:35:36

\begin{tabular}{|c|c|c|c|c|c|c|c|c|c|c|c|c|c|c|}
\hline & $\begin{array}{l}\text { plenum } \\
\text { exposed }\end{array}$ & $\begin{array}{l}\text { Feed } \\
\text { Rate }\end{array}$ & $\begin{array}{c}\text { Bubbling } \\
\text { Rate }\end{array}$ & $\begin{array}{l}\text { Heated } \\
\text { FC air }\end{array}$ & $\begin{array}{c}\text { FC } \\
\text { Outlet }\end{array}$ & $\begin{array}{c}\text { Transition } \\
\text { Outlet }\end{array}$ & $\begin{array}{l}\text { Stack } \\
\text { Flow }\end{array}$ & $\begin{array}{l}\text { Stack } \\
\text { Flow }\end{array}$ & $\begin{array}{l}\text { Stack } \\
\text { Flow }\end{array}$ & $\mathrm{H}_{2}$-GC & $\begin{array}{c}\mathrm{H}_{2^{-}} \\
\text {Sensor }\end{array}$ & $\mathrm{CO}$ & $\mathrm{CO}_{2}$ & $\mathrm{H}_{2} \mathrm{O}$ \\
\hline & $\left({ }^{\circ} \mathrm{C}\right)$ & $(\mathrm{kg} / \mathrm{hr})$ & $(\mathrm{lpm})$ & $\left({ }^{\circ} \mathrm{C}\right)$ & $\left({ }^{\circ} \mathrm{C}\right)$ & $\left({ }^{\circ} \mathrm{C}\right)$ & dscfm & scfm & acfm & ppm & $\mathrm{ppm}$ & ppm & vol $\%$ & vol $\%$ \\
\hline average & 526.57 & 3.09 & 1.9 & 245.7 & 295.1 & 248.1 & 18.08 & 20.02 & 24.58 & 90.28 & $\mathrm{n} / \mathrm{a}$ & 100.66 & 0.370 & 9.730 \\
\hline std dev & 4.58 & 0.14 & 0.17 & 1.73 & 3.83 & 3.18 & 0.47 & 0.49 & 7.90 & 15.08 & $\mathrm{n} / \mathrm{a}$ & 24.10 & 0.042 & 1.158 \\
\hline $\max$ & 533.72 & 3.29 & 2.1 & 249.2 & 303.5 & 263.5 & 20.91 & 23.24 & 41.82 & 112.28 & $\mathrm{n} / \mathrm{a}$ & 183.71 & 0.495 & 13.503 \\
\hline $\min$ & 516.44 & 2.59 & 1.5 & 243.3 & 281.2 & 245.7 & 17.09 & 19.43 & 17.09 & 64.78 & $\mathrm{n} / \mathrm{a}$ & 60.79 & 0.298 & 7.652 \\
\hline
\end{tabular}

From: 01/21/2011 10:33:49

To: 01/21/2011 11:01:49

\begin{tabular}{|c|c|c|c|c|c|c|c|c|c|c|c|c|c|c|}
\hline & $\begin{array}{c}\text { plenum } \\
\text { exposed }\end{array}$ & $\begin{array}{l}\text { Feed } \\
\text { Rate }\end{array}$ & $\begin{array}{c}\text { Bubbling } \\
\text { Rate }\end{array}$ & $\begin{array}{l}\text { Heated } \\
\text { FC air }\end{array}$ & $\begin{array}{c}\text { FC } \\
\text { Outlet }\end{array}$ & $\begin{array}{c}\text { Transition } \\
\text { Outlet }\end{array}$ & $\begin{array}{l}\text { Stack } \\
\text { Flow }\end{array}$ & $\begin{array}{l}\text { Stack } \\
\text { Flow }\end{array}$ & $\begin{array}{l}\text { Stack } \\
\text { Flow }\end{array}$ & $\mathrm{H}_{2}$-GC & $\begin{array}{c}\mathrm{H}_{2-} \\
\text { Sensor }\end{array}$ & $\mathrm{CO}$ & $\mathrm{CO}_{2}$ & $\mathrm{H}_{2} \mathrm{O}$ \\
\hline & $\left({ }^{\circ} \mathrm{C}\right)$ & $(\mathrm{kg} / \mathrm{hr})$ & $(\mathrm{lpm})$ & $\left({ }^{\circ} \mathrm{C}\right)$ & $\left({ }^{\circ} \mathrm{C}\right)$ & $\left({ }^{\circ} \mathrm{C}\right)$ & dscfm & scfm & acfm & ppm & $\mathrm{ppm}$ & $\mathrm{ppm}$ & vol\% & vol\% \\
\hline average & 428.12 & 3.21 & 2.1 & 245.9 & 279.7 & 239.8 & 18.98 & 20.87 & 25.48 & 88.33 & $\mathrm{n} / \mathrm{a}$ & 78.64 & 0.350 & 9.074 \\
\hline std dev & 4.58 & 0.23 & 0.02 & 1.09 & 5.09 & 2.10 & 0.54 & 0.53 & 7.94 & 18.09 & $\mathrm{n} / \mathrm{a}$ & 23.90 & 0.054 & 1.446 \\
\hline $\max$ & 436.57 & 3.82 & 2.2 & 248.1 & 287.2 & 244.9 & 20.65 & 22.56 & 39.75 & 106.10 & $\mathrm{n} / \mathrm{a}$ & 171.51 & 0.539 & 14.000 \\
\hline $\min$ & 422.315 & 2.72 & 2.1 & 244.4 & 268.2 & 237.5 & 17.87 & 20.23 & 17.87 & 66.50 & $\mathrm{n} / \mathrm{a}$ & 43.99 & 0.288 & 6.954 \\
\hline
\end{tabular}

From: 01/21/2011 13:30:02

To: 01/21/2011 14:58:57

\begin{tabular}{|c|c|c|c|c|c|c|c|c|c|c|c|c|c|c|}
\hline & $\begin{array}{l}\text { plenum } \\
\text { exposed }\end{array}$ & $\begin{array}{l}\text { Feed } \\
\text { Rate }\end{array}$ & $\begin{array}{c}\text { Bubbling } \\
\text { Rate }\end{array}$ & $\begin{array}{c}\text { Heated } \\
\text { FC air }\end{array}$ & $\begin{array}{c}\text { FC } \\
\text { Outlet }\end{array}$ & $\begin{array}{c}\text { Transition } \\
\text { Outlet }\end{array}$ & $\begin{array}{l}\text { Stack } \\
\text { Flow }\end{array}$ & $\begin{array}{l}\text { Stack } \\
\text { Flow }\end{array}$ & $\begin{array}{l}\text { Stack } \\
\text { Flow }\end{array}$ & $\mathrm{H}_{2}-\mathrm{GC}$ & $\begin{array}{c}\mathrm{H}_{2^{-}} \\
\text {Sensor }\end{array}$ & $\mathrm{CO}$ & $\mathrm{CO}_{2}$ & $\mathrm{H}_{2} \mathrm{O}$ \\
\hline & $\left({ }^{\circ} \mathrm{C}\right)$ & $(\mathrm{kg} / \mathrm{hr})$ & (lpm) & $\left({ }^{\circ} \mathrm{C}\right)$ & $\left({ }^{\circ} \mathrm{C}\right)$ & $\left({ }^{\circ} \mathrm{C}\right)$ & dscfm & scfm & acfm & $\mathrm{ppm}$ & $\mathrm{ppm}$ & $\mathrm{ppm}$ & vol\% & vol $\%$ \\
\hline average & 336.79 & 3.16 & 2.2 & 246.9 & 230.2 & 221.6 & 29.41 & 31.04 & 37.65 & 49.58 & 44.64 & 47.06 & 0.212 & 5.232 \\
\hline std dev & 3.95 & 0.20 & 0.01 & 1.07 & 2.14 & 2.79 & 0.95 & 0.91 & 10.60 & 8.54 & 6.02 & 11.21 & 0.021 & 0.786 \\
\hline $\max$ & 343.975 & 4.07 & 2.2 & 248.2 & 236.3 & 226.8 & 32.31 & 33.95 & 57.18 & 69.91 & 60.59 & 88.11 & 0.305 & 8.270 \\
\hline $\min$ & 324.275 & 2.79 & 2.2 & 244.4 & 226.7 & 217.0 & 27.52 & 29.74 & 27.52 & 37.78 & 28.89 & 29.64 & 0.181 & 3.973 \\
\hline
\end{tabular}


From: 01/21/2011 15:18:59

To: $01 / 21 / 2011$ 16:33:29

\begin{tabular}{|c|c|c|c|c|c|c|c|c|c|c|c|c|c|c|}
\hline & $\begin{array}{l}\text { plenum } \\
\text { exposed }\end{array}$ & $\begin{array}{l}\text { Feed } \\
\text { Rate }\end{array}$ & $\begin{array}{c}\text { Bubbling } \\
\text { Rate }\end{array}$ & $\begin{array}{l}\text { Heated } \\
\text { FC air }\end{array}$ & $\begin{array}{c}\text { FC } \\
\text { Outlet }\end{array}$ & $\begin{array}{c}\text { Transition } \\
\text { Outlet }\end{array}$ & $\begin{array}{l}\text { Stack } \\
\text { Flow }\end{array}$ & $\begin{array}{l}\text { Stack } \\
\text { Flow }\end{array}$ & $\begin{array}{l}\text { Stack } \\
\text { Flow }\end{array}$ & $\mathrm{H}_{2}-\mathrm{GC}$ & $\begin{array}{c}\mathrm{H}_{2^{-}} \\
\text {Sensor }\end{array}$ & $\mathrm{CO}$ & $\mathrm{CO}_{2}$ & $\mathrm{H}_{2} \mathrm{O}$ \\
\hline & $\left({ }^{\circ} \mathrm{C}\right)$ & $(\mathrm{kg} / \mathrm{hr})$ & (lpm) & $\left({ }^{\circ} \mathrm{C}\right)$ & $\left({ }^{\circ} \mathrm{C}\right)$ & $\left({ }^{\circ} \mathrm{C}\right)$ & dscfm & scfm & $\mathrm{acfm}$ & ppm & $\mathrm{ppm}$ & ppm & vol\% $\%$ & vol $\%$ \\
\hline average & 257.93 & 3.13 & 2.2 & 246.3 & 214.4 & 207.1 & 33.76 & 35.39 & 42.41 & 46.40 & 44.41 & 43.25 & 0.193 & 4.607 \\
\hline std dev & 3.93 & 0.11 & 0.03 & 1.37 & 1.80 & 1.90 & 0.26 & 0.12 & 11.11 & 11.21 & 5.13 & 9.43 & 0.019 & 0.704 \\
\hline $\max$ & 263.955 & 3.36 & 2.4 & 248.1 & 217.3 & 209.8 & 34.42 & 35.88 & 59.04 & 75.72 & 56.37 & 77.56 & 0.281 & 7.060 \\
\hline $\min$ & 249.6 & 2.71 & 2.1 & 244.2 & 210.9 & 202.6 & 32.86 & 35.10 & 32.86 & 25.59 & 28.78 & 25.12 & 0.164 & 3.007 \\
\hline
\end{tabular}




\section{Distribution:}
A. B. Barnes, 999-W
D. A. Crowley, 773-43A
A. P. Fellinger, 773-41A
S. D. Fink, 773-A
B. J. Giddings, 786-5A
C. C. Herman, 999-W
S. L. Marra, 773-A
A. M. Murray, 773-A
F. M. Pennebaker, 773-42A
W. R. Wilmarth, 773-A
J. M. Bricker, 704-27S
T. L. Fellinger, 704-26S
J. M. Gillam, 766-H
B. A. Hamm, 766-H
E. W. Holtzscheiter, 704-15S
J. F. Iaukea, 704-30S
M. T. Keefer, 766-H
D. W. Mcilmoyle, 766-H
J. E. Occhipinti, 704-S
D. K. Peeler, 999-W
J. W. Ray, 704-S
H. B. Shah, 766-H
D. C. Sherburne, 704-S
A. V. Staub, 704-27S
M. E. Stone, 999-W
P. R. Jackson, DOE-SR, 703-46A
K. H. Subramanian, 766-H 